\title{
CLIENTS, LAWYERS AND THE FIFTH AMENDMENT: THE NEED FOR A PROJECTED PRIVILEGE
}

\author{
KEVIN R. REITZ*
}

INTRODUCTION $\ldots \ldots \ldots \ldots \ldots \ldots \ldots \ldots \ldots \ldots \ldots \ldots \ldots \ldots, 573$

I. The Suspect's Rights of Testimonial Passivity ...... 576

A. The Rights of Passivity Under Existing Law ......... 576

B. Bases of the Rights ......................... 580

II. Counsel's Obligations to COME ForWARD WITH INCRIMINATING EVIDENCE IN THE ABSENCE OF A

SPECIFIC Legal CoMMAND......................... 584

A. The Olwell Line of Cases ...................... 584

1. State v. Olwell ........................... 585

2. Morrell v. State.......................... 587

3. People v. Meredith ........................ 592

4. Summary............................... 594

B. Legal Bases of the Olwell Rule .................. 594

1. Obstruction Laws ........................... 597

2. Contraband Laws ........................ 598

C. Policies and Emotions of the Olwell Rule ............ 600

1. Anti-Hindrance Policies ...................... 600

2. Emotions ............................... 603

D. Must the Olwell Rule be Extended to Incriminating Documents in White-Collar Cases? .................. 605

E. The Reach of the Olwell Rule .................... 608

1. Standard of Knowledge....................... 608

2. Retrospective Application .....................6 611

F. Transition ................................. 612

III. COUNSEl's Obligation to COME ForWARD WITH INCRIMINATING EVIDENCE WHEN Placed UNDER SPECIFIC LEgal CoMMAND....................... 613

A. The Fifth Amendment Under Fisher v. United States .. 615

1. The "Simulated" Privilege ................... 616

* Associate Professor, University of Colorado School of Law. I owe thanks to my colleagues who reviewed earlier drafts of this Article: Michael Bender, Richard Delgado, Pat Furman, Dennis Hall, Lynne Henderson, Hiroshi Motomura, Charles Pengilly, Bill Pizzi, and Steve Smith. My best and most valued editor through many drafts was my father. 
2. The Client's "Act of Production" Privilege .......... 618

3. United States v. Doe (Doe I) and the Immunity Loophole .................................... 623

B. Can Fisher and Olwell Coexist?................ 627

1. Relitigating O1well ........................ 628

2. Is the Simulated Privilege Based in the Constitution?............................. 636

C. Legal Commands Not Subject to the Fifth Amendment Under Fisher............................. 638

1. The Limitations of the Attorney-Client Privilege ..... 639

D. Summary of Parts II and III ................... 648

IV. The Need for a Projected Fifth Amendment

Privilege..................................... 650

A. Statement of the Projected Privilege .............. 651

B. The Solution to the Depository Problem: The "Hybrid

Order"....................................... 654

1. Mechanics ............................. 654

2. Constitutional Objections ................... 658

v. Conclusion .................................. 659

\section{INTRODUCTION}

Under current law, it could be a serious mistake for a suspect in a criminal case to obtain counsel. For years, the courts have recognized specific instances where defense lawyers inust behave as government agents or informants, providing chent-incriminating evidence and information to prosecutors. In recent times, this once-narrow category of cases has shown dramatic growth as prosecutors have increasingly turned to defense lawyers as sources of evidence, and have increasingly inet with success. It is time to reevaluate across-the-board how the law should respond to such developments.

The early cases, starting with State v. Olwell, ${ }^{1}$ concerned physical evidence of violent crime (such as alleged inurder weapons) but broadly held that defense lawyers had an affirmative duty to coine forward on their own initiative with relevant client-incriminating evidence in their possession..$^{2}$ Failure to do so, in fact, could be a criminal offense. ${ }^{3}$ If we

1. 394 P.2d 681 (Wash. 1964).

2. See id. at 684 . In some cases, the attorney may ultimately be required to testify against her client (now probably a former client) regarding the history of the evidence produced, where it was found, who originally had possession, and other knowledge the attorney may have about the evidence. See, e.g., Morrell v. State, 575 P.2d 1200 (Alaska 1978); People v. Meredith, 631 P.2d 46 (Cal. 1981). Morrell and Meredith are discussed at length infra in Part II(A)(2) and Part II(A)(3), respectively. 
are to take the Olwell line of decisions seriously - and they are still on the books - their import is far-reaching. Notably, defense lawyers in whitecollar criminal cases would be required to supply to a prosecutor all relevant documents that are potentially incriminating to their clients. ${ }^{4}$

Meanwhile, an analogous set of problems has been quickly developing on a different front. Beginning in the early 1980s, the government has steadily increased its use of grand jury subpoenas and other legal commands directed to defense counsel in pursuit of client-incriminating evidence and testimony. 5 Althougl the courts evinced an early hesitation to enforce such legal commands, the tide has turned in recent appellate decisions. Where exceptions to the traditional safeguards of the attorney-client privilege and work product doctrine can be found, the files and memories of defense lawyers have proven remarkably accessible to prosecutors. These developments are soinetimes perceived as part of a so-called governmental "war" upon defense counsel and the unpopular constitutional liberties of their clients. Whether or not this appellation is correct, it is undeniable that a significant volume of litigation is now occurring, and that the list of nuaterials and testimony accessible to the government is lengthening. ${ }^{6}$

The Suprenie Court has spoken only to a sinall subset of the issues arising under Olwell and the legal coniniand cases, but the time for a major decision may be nearing. Privileges are seldom created in the abstract; the need for them must first appear. We have reached such a juncture now, where investigative techıriques are outdistancing old safeguards. The Court may soon step in, as it did in the venerable decision of Hickman v. Taylor, ${ }^{7}$ which created the work product doctrine or, more

3. See, e.g., Morrell, 575 P.2d at 1211 (stating that lawyer might have violated Alaska's concealment of evidence statute if he had failed to produce chient-incriminating evidence to police); In re Ryder, 263 F. Supp. 360, 370 (E.D. Va.) (holding that lawyer's failure to produce evidence violated state law concerning receipt of stolen property and federal law concerning receipt and possession of a firearm), aff'd, 381 F.2d 713 (4th Cir. 1967).

4. There is no principled reason to distinguish a lawyer's duties with respect to a sunoking-gun document from those regarding a sinoking gun. See infra Part II(D).

5. See United States v. Perry, 857 F.2d 1346, 1347 (9th Cir. 1988) (discussing the government's apparently increasing use of grand jury subpoenas on a target's counsel); Max Stern \& David Hoffinan, Privileged Informers: The Attorney Subpoena Problem and a Proposal for Reform, $136 \mathrm{U}$. PA. L. REv. 1783, 1787-89 (1988) (reporting an "explosion of subpoenas to lawyers" since the early 1980s); Breckinridge L. Willcox, Martin Marietta and the Erosion of the Attorney-Client Privilege and Work Product Protection, 49 MD. L. Rev. 917, 940 (1990); Dan LeDuc, Lawyer Jailed for Contempt, NAT'L L.J., Feb. 4, 1991, at 3.

6. Thus, for example, defense lawyers have been compelled to betray confidences concerning the undisclosed identities of their clients, fee arrangements with clients, and fee-payer relationships that demonstrate the client's involveinent with others suspected in a criminal conspiracy. See generally infra Part III(C).

7. 329 U.S. 495 (1947). 
recently, in Fisher v. United States ${ }^{8}$ and Upjohn Co. v. United States, ${ }^{9}$ which gave new force to the attorney-chent privilege. If the Court does not move to occupy the field, however, the same issues will be left for resolution by legislatures, state courts, and drafters of codes of professional conduct.

I propose a unified solution to the range of problems outlined above through the adoption of a new "projected" Fifth Amendment privilege that would permit lawyers to assert their chents' self-mcrimination privilege with respect to mcriminatimg evidence and information lawfully acquired during the representation. The projected privilege would be available to counsel $\mathrm{m}$ all circumstances $\mathrm{m}$ which the chent could claim a lawful ability under the Fifth Amendment to resist disclosure of the same evidence or information. Its driving principle is the preservation of a constitutional status quo defined by the chent's self-mcrimination rights in the absence of representation by an attorney.

In conjunction with the projected privilege, I address the problem of how law enforcement agencies may be expected to reach physical evidence once im counsel's possession. Here I suggest that a new imvestigative tool be created, with shared characteristics of a search warrant and subpoena. Based upon a showing of probable cause and the satisfaction of other Fourth Amendment requirements, this "hybrid order" could command defense lawyers to produce evidence in their possession under the legal fiction that a "constructive search" had taken place.10 Returning to the status quo rationale that drives the projected privilege, the hybrid order seeks to ensure that evidence in a lawyer's possession remains accessible to the government on terms coinparable to those in effect when the evidence is in the possession of the client or some other private party.

The ultimate goal of the projected privilege and hybrid order is a level playing field. The reforms do not substantially reduce the amount of evidence accessible to the prosecution, but they do remove the wedge driven between lawyer and chent by the present law-which compels counsel to serve as a government agent or informant by producing evidence that the chent could lawfully shield.

Part I of this Article examines the coinplex of Fifth Amendment rights enjoyed by a suspect during a criminal investigation, which I call

8. 425 U.S. 391 (1976). Fisher is discussed in detail infra in Part III(A).

9. 449 U.S. 383 (1981).

10. In my view, the hybrid order might be constitutionally permissible given the government's greater power to conduct an actual search under Fourth Amendment strictures, and the fact that a constructive search would be more protective of confidential matter in the lawyer's possession than actual search procedures. See infra Part IV(B). 
"rights of testimonial passivity." This discussion relates solely to the suspect, as though unrepresented by counsel, to define the general terms of the constitutional status quo. Parts II and III study a series of problenıs under existing law, which places defense lawyers under soine form of obligation to supply chent-incriminating evidence to the government. Part II examines the Olwell cases, in which counsel is thought to have a self-activating duty to produce evidence. Part III deals with cases in which lawyers have received a specific legal conmmand to coine forward, as by subpoena or court order. The force and linitations of the Supreme Court's ruling in Fisher v. United States ${ }^{11}$ will occupy nuch of the discussion in Part III. By some readings, Fisher has invalidated the Olwell cases, ${ }^{12}$ but this is a difficult question that requires close exploration. Although Fisher's analysis is largely at odds with Olwell, state courts are not bound to treat Fisher as controlling precedent.

Parts II and III provide illustrations of the law's failure to extend suspects' riglits of passivity to their counsel, building toward the argument in Part IV that we should rethink all of the problems confronted in the Article as matters of Fiftl Amendnient concern. On a snialler scale, lowever, Parts II and III stand by theniselves. They largely deal with existing law, its niadequacies and internal contradictions, and the adjustnients that nuust be niade short of the unified solutions offered in Part IV. Even if the projected privilege and hybrid order are quickly forgotten, the "smaller" observations offered ni Parts II and III reinain worthy of attention.

\section{The Suspect's Rights of Testimonial Passivity}

\section{A. The Rights of Passivity Under Existing Law}

During a criminal investigation, a suspect ${ }^{13}$ has a coniplex of Fifth Amendment riglits that I will refer to as "rights of testimonial passivity" or simply "rights of passivity." 14 In a variety of circumstances, the selfincrimination clause permits the suspect to refram fron giving assistance

11. 425 U.S. 391 (1976).

12. See infra Part III(B); see also Michael L. Bender, Incriminating Evidence: What to Do with a Hot Potato, 11 CoLo. LAw. 880, 889-90 (1982) (discussing the interplay between Fisher and Olwell); Norman Lefstein, Incriminating Physical Evidence, the Defense Attorney's Dilemma, and the Need for Rules, 64 N.C. L. REv. 897, 913-15 (1986) (exploring the relationship between Fisher and Olwell).

13. Throughout this Article I use the term "suspect" loosely to include people who are under government suspicion of having committed a crime, as well as others who are inerely concerned about potential criminal liability. The term is not meant to imply that any particular stage of a criminal investigation or proseeution has been reached.

14. This is not a common usage, but $I$ think it descriptive of the particular Fifth Amendment guarantees examined in this paper. See infra Part $\mathrm{I}(\mathrm{B})$. 
to the government, even when the government demands it. His cooperation may be withheld when the Fifth Amendment privilege exists, but may lawfully be compelled when the privilege is thought not to apply. The Supreme Court has developed a simple model of three requirements that a suspect must satisfy to establish a right to remain passive: $\mathrm{He}$ must show "compulsion" exerted upon him to engage in "testimomal" behavior that is "self-mcriminatimg." three is fatal to the claim of passivity.

The Supreme Court has defined "testimomal" behavior to include nonverbal conduct that conveys factual assertions or discloses information. ${ }^{16}$ The privilege is said to safeguard against the compulsion of incriminatimg revelations, through word or deed, that are expressive of the contents of the suspect's mind. 17 Within this broad protection lie many recognized instances in which a suspect has the right to stand apart, or remain passive, during a criminal mvestigation. The most familiar are the right to silence at trial and during custodial interrogation. ${ }^{18}$ In no setting, however, may a suspect be forced to divulge the naines of his friends or associates, or of the person who has retained and paid for his lawyer, if such facts might mcriminate him. ${ }^{19}$ In addition, a suspect may not be compelled to produce physical evidence of crime where the act of production would imphedly admit that the evidence exists or that the suspect has control over it, or would supply information contributing to the authentication of the evidence. ${ }^{20}$ Accordingly, it has been held that a

15. See Doe v. United States (Doe II), 487 U.S. 201, 207 (1988); Fisher v. United States, 425 U.S. 391, 409 (1976).

16. See Muniz, $110 \mathrm{~S}$. Ct. at 2643; Doe II, 487 U.S. at 210.

17. Doe $I, 487$ U.S. at 210-11 \& n.9.

18. See, e.g. , Miranda v. Arizona, 384 U.S. 436 (1966) (right to silence during custodial interrogation); Griffin v. California, 380 U.S. 609 (1965) (right to silence at trial). The privilege, of course, extends to nunierous other contexts. See, eg., Estelle v. Smith, 451 U.S. 454 (1981) (psychiatric examination); McCarthy v. Amdstein, 266 U.S. 34 (1924) (bankruptcy proceeding); Counselinan v. Hitchcock, 142 U.S. 547 (1892) (grand jury proceedings). The Court stated in In re Gault, 387 U.S. 1 (1967), that "the availability of the privilege does not turn upon the type of proceeding in which its protection is invoked, but upon the nature of the stateinent or admission and the exposure which it invites." Id. at 49; accord Lefkowitz v. Turley, 414 U.S. 70, 77 (1973).

19. In Malloy v. Hogan, 378 U.S. 1 (1964), the Court held that the petitioner, who had previously pleaded guilty and been sentenced for a gambling offense, could successfully interpose his Fifth Amendment privilege when he was later called to testify before a court-appointed referee investigating gambling in the county. See id. at 12-14. Petitioner was asked, among other things, who had selected and paid for his lawyer, who had selected and paid for his bondsnan, who had paid his fine, and whether he knew an individual named Jolin Bergoti. Id. at 12. The Court held that petitioner's answers "might furnish a link in a chain of evidence sufficient to connect the petitioner with a inore recent crime for which he might still be prosecuted." Id. at 13.

20. See United States v. Doe (Doe I), 465 U.S. 605 (1984); Fisher v. Uurited States, 425 U.S. 391 (1976); infra Part III(A)(2). 
suspect cannot be required to produce potentially incriminating docuinents, ${ }^{21}$ tape recordings, ${ }^{22}$ or even a weapon allegedly used in the offense. $^{23}$

Forms of self-inculpatory cooperation may be compelled, however, when not deemed "testimonial," as when a suspect is required to supply a blood sample ${ }^{24}$ or stand in a hineup. ${ }^{25}$ In such settings, although the suspect is required to be an active participant in the criminal case against himself, his assistance is not viewed as testimonial because it fails to reveal the contents of his mind. On occasion, even verbal conduct has been deemed nontestimonial under this theory. Recently the Supreme Court found the privilege inapplicable when a grand jury target was ordered to sign a consent form authorizing foreign banks to disclose records of his accounts, ${ }^{26}$ and when a man arrested for drunk driving incriminated himself through the slurring of his speech while trying to complete a sobriety test. ${ }^{27}$

Infrequently, a Fifth Amendment claim may fail because the testimonial assistance sought from the suspect does not carry a sufficient risk of "mcrimination" to be of constitutional concern. ${ }^{28}$ The relevant standard is lenient, holding the incrimination requirement satisfied whenever the suspect's requested behavior might prove self-incriminatory. This embraces testimomal assistance that could itself be used as evidence at trial to support conviction, but extends beyond this to any information that would "furnish a link in the chain of evidence needed to prosecute the claimant."29

A suspect, of course, cannot be required to demonstrate the precise nature of the morimination that might result if his testmonial assistance

21. See Doe $I, 465$ U.S. at $612-14$.

22. See In re Vanderbilt, 439 N.E.2d 378 (N.Y. 1982).

23. See Goldsmith v. Superior Court, 199 Cal. Rptr. 366 (Cal. Ct. App. 1984) (refusing to compel defendant in attempted murder case to produce gun); Commonwealth v. Hughes, 404 N.E.2d 1239 (Mass.) (holding order to produce gun in assault case unenforceable under Fifth Amendment act of production privilege), cert. denied, 449 U.S. 900 (1980); infra Part III(B)(1).

24. See Schmerber v. California, 384 U.S. 757, 765 (1966).

25. See United States v. Wade, 388 U.S. 218, 221-22 (1967); see also United States v. Dionisio, 410 U.S. 1 (1973) (voice exemplar); Gilbert v. California, 388 U.S. 263 (1967) (handwriting exemplar).

26. Doe v. United States (Doe II), 487 U.S. 201, 215 (1988) (holding that execution of consent directive is not testimonial because no factual assertions, implicit or explicit, are conveyed to the government).

27. Pennsylvania v. Muniz, 110 S. Ct. 2638,2645 (1990).

28. See United States v. Apfelbaum, 445 U.S. 115, 118 (1980) (de minimis threat of self-incrimination does not implicate Fifth Amendment); Marcletti v. United States, 390 U.S. 39, 53 (1968) (risk of incrimination must be substantial and real, not merely trifling or imaginary).

29. Hoffman v. United States, 341 U.S. 479, 486 (1951) (emphasis added); accord Maness v. Meyers, 419 U.S. 449, 461 (1975). 
were compelled. Such a requirement would call upon him to forfeit the privilege in order to assert it. ${ }^{30}$ Instead, a judge ruling upon the issue must weigh the imphications of the questions asked and the setting im which they are asked, and inay overrule the suspect's claim of mcrimination only when it is " perfectly clear, from a careful consideration of all the circumstances in the case, that the witness is mistaken, and that the answer[s] cannot possibly have such tendency' to incriminate." 31 In the rare case, courts have found that a person's assertion of potential selfincrimination was too msubstantial to be honored. ${ }^{32}$ The privilege is most likely to yield on such a ground when the witness has already been convicted and sentenced for the crime about which he is now being asked to supply evidence or information, ${ }^{33}$ or when the government has granted him immunity. ${ }^{34}$

Finally, a few words about the compulsion requirement. There is no constitutional rule that a suspect cannot voluntarily engage im testimomal self-incrimination. We do not prohibit or even discourage confessions that are freely given, ${ }^{35}$ and the same is true of other forms of cooperation a suspect may choose to afford a prosecutor. The ability to remain silent or passive grows out of the behef that individuals should be free of coinpulsion to come forward with mcriminating information. ${ }^{36}$ As the Court has said, the privilege is fulfilled only when a suspect is guaranteed the right "to remain silent unless he chooses to speak in the unfettered exercise of his own will."37

30. See Hoffman, 341 U.S. at 486.

31. Id. at 488 (quoting Temple v. Commonwealth, $75 \mathrm{Va} .892,898$ (1881)); accord Malloy v. Hogan, 378 U.S. 1, 11-12 (1964); Counselman v. Hitchcock, 142 U.S. 547, $579-80$ (1892).

32. See, e.g., Zicarelli v. New Jersey State Comm'n of Investigation, 406 U.S. 472, 478 (1972); 15,844 Welfare Recipients v. King, 474 F. Supp. 1374, 1385 (D. Mass. 1979).

33. Even this scenario is not always sufficient to overcome a claim of privilege. See Malloy, 378 U.S. at 12-14.

34. In Brown v. Walker, 161 U.S. 591 (1896), the Court first adopted the view that immunized testimony could not be considered incriminating once the danger of criminal prosecution had been removed. See also Kastigar v. United States, 406 U.S. 441, 453 (1972) (holding that immunity from the use and derivative use of testimony is "sufficient to compel testimony over a claim" of Fifth Amendment privilege). On similar reasoming, a witness cannot claim the privilege as to crimes for which she has been pardoned or for which the statute of limitations has run. See WAYNE R. LaFave \& Jerold H. ISRaei, Criminal Procedure § 8.11, at 393 (1985).

35. As stated in Miranda v. Arizona, 384 U.S. 436 (1966), "[v]oluntecred statements of any kind are not barred by the Fifth Amendment." Id. at 478 . See also Minnick v. Mississippi, $111 \mathrm{~S}$. Ct. 486, 492 (1990) ("Both waiver of rights and admission of guilt are consistent with the affirmation of individual responsibility that is a principle of the crininal justice system.").

36. See Joseph D. Grano, Voluntariness, Free Will and the Law of Confessions, 65 VA. L. REv. 859, 937 (1979).

37. Malloy v. Hogan, 378 U.S. 1, 8 (1964), quoted with approval in Estelle v. Smith, 451 U.S. 454, 468 (1981). 


\section{B. Bases of the Rights}

Because this Article ultimately asserts that the suspect's constitutional rights of passivity should be given force in settings in which they are not presently recognized, it is well to recanvass the reasons that those rights are deserving of constitutional protection in the first instance. ${ }^{38}$ There is a vast hiterature and continuing debate concerning the supportability of the privilege when subjected to constitutional, historical, utilitarian, and inoral scrutiny. ${ }^{39}$ The following abbreviated treatınent of the issue is intended to locate this Article within the ongoing debate.

The self-incrimination privilege reflects value judgments concerning both human nature and the nature of the criminal justice process. As to the fornier, the privilege recogmizes that inost people share an impulse toward self-defense when placed under attack. This instinct is countermanded in the most violent way possible when a person is forced not merely to endure an injury, but to inflict self-harm of any serious kind. Thus, in the language of the Fifth Amendinent cases, we view the enforced self-harm of self-incrimination on its face as "cruel" or as "destructive of [the] digmity" of the accused.40

The inagmitude of the violation of huinan personality occasioned by the coinpelled infliction of self-harm varies with the particular harn involved. The more substantial the harm, the greater should be our hesitancy to allow the government to cominand self-infliction. This helps

38. For the purposes of my argument, it might be sufficient to observe that suspects' rights of passivity are a matter of federal constitutional law, binding upon the states. Any further justification could be relegated "beyond the scope" of the present work. However, it strikes me as unsatisfying to say nothing more about passivity rights than "we have them and we're stuck with them."

39. See, eg., ERWIN N. GRISWOLd, The FifTh AMENDMENT TODAY (1955); LeONARD W. LeVy, ORIGINS OF THE FifTh AMENDMENT (2d ed. 1984); LeWIS MAYers, Shall We AMEND THE FifTH AMENDMENT? (1959); 7 THE WORKS OF JEREMY BeNTHAM 445-72 (John Bowring ed., 1843); David Dolinko, Is There a Rationale for the Privilege Against Self-Incrimination?, 33 UCLA L. REV. 1063 (1986); Donald A. Dripps, Self-Incrimination and Self-Preservation: A Skeptical View, 1991 U. ILL. L. REV. 329; Henry J. Friendly, The Fifth Amendment Tomorrow: The Case for Constitutional Change, 37 U. CIN. L. REV. 671 (1968); R. Kent Greenawalt, Silence as a Moral and Constitutional Right, 23 WM. \& MARY L. REV. 15 (1981); Erwin N. Griswold, The Right to Be Let Alone, 55 Nw. U. L. REv. 216 (1961); R.H. Helmholz, Origins of the Privilege Against Self-Incrimination: The Role of the European Ius Commune, 65 N.Y.U. L. REv. 962 (1990); John T. McNaughton, The Privilege Against Self-Incrimination: Its Constitutional Affectation, Raison d'Etre and Miscellaneous Implications, 51 J. CRIM. L. CRIminology \& Police SCr. 138 (1960); Michael A. Meulowe, Bentham, Self-Incrimination, and the Law of Evidence, 104 LAW Q. REV. 286 (1988); William J. Stuntz, Self-Incrimination and Excuse, 88 Colum. L. REv. 1227 (1988); George C. Thomas \& Marshall D. Bilder, Aristotle's Paradox and the Self-Incrimination Puzzle, 82 J. CrIM. L. \& CRIMINology 243 (1991).

40. See Schmerber v. California, 384 U.S. 757, 762 (1966); Miranda v. Arizona, 384 U.S. 436, 457 (1966). 
explain the restriction of the self-incrimination privilege to persons exposed to criminal hability. The criminal process is different in kind from any other interaction between the state and its citizens. From the perspective of the accused, the stakes are never higher or more personal in his relationship to the government.

Merely observing that there exists a shared aversion toward compelled serious self-harm, however, does not by itself validate legal recognition of this facet of human nature. ${ }^{41}$ Perhaps, as with most human impulses, it should be permitted expression in soine situations but not in others. We nuust here focus upon the desirability of allowing the suspect to avoid self-harm when compelled by the government during a criminal case.

A critic of the Fifth Amendment privilege might argue, on moral grounds, that a criminal forfeits his interest in avoiding compelled selfharın when he comımits a crime. Alternatively, on utilitarian grounds, it imght be said that all members of society should wish for a rule that calls upon them to respond to questions, or demands that they produce evidence, when they come under suspicion of criminal conduct, with the understanding that the net result of such a rule would be greater enforcement of the criminal laws. Certainly, comproimises of this kind exist elsewhere in our constitutional law. The Fourth Amendment, for example, contemplates "reasonable" intrusions upon individual hiberties when outweighed by the interests of law enforcement. ${ }^{42}$ Why should the self-incrimination prerogative be less flexible?

The answer is found in the unique character of the act of self-incrimination not merely as an affirmative act of self-betrayal, but also as an act of "joining" in the coercive action of the state. There is a vast difference between holding a person subject to the criminal laws as enforced by others, and holding that he must serve, however reluctantly, as one of his own accusers. The latter intrusion upon individual freedom is different in kind from the foriner. A rule permitting compelled self-incrimination would require the accused to ratify the process mounted against him through his own participation; it would forbid him the right to protest the justice of the state's action through passive abstention from its execution.

The Fifth Amendinent grants the suspect the right to make a choice, not subject to anyone else's control, of whether he will join in his own

41. Certainly, there are human instincts to which society has chosen not to give legal sanction in all instances. Aggressive urges toward violence and homicide, for example, are not enshrined in the law as positive qualities worthy of protection.

42. See, e.g., Michigan Dep't of State Police v. Sitz, 110 S. Ct. 2481, 2488 (1990); Terry v. Ohio, 392 U.S. 1,27 (1968). 
prosecution. Even if guilty of the offense at issue, the privilege allows him to withhold a part of himself from the process. As I have mentioned, this result is tolerated $\mathrm{m}$ part because of the high stakes involved in a criminal case-but there is another reason for the privilege. The suspect's passivity is tolerated also because we hold deep-seated doubts concerning the inoral perfection of our criminal justice systein, and we correspondingly respect the right of the individual accused to question the criminal law's application to him. Thus, we allow the suspect to maintain the following position of autonomy:

I acknowledge that $I$ am subject to the laws as a member of society, but $I$ retain the right to doubt the justness of their application in my case. The government can require me to appear in a courtroom, it can require me to submit to punishment, but it cannot call upon me to lend my aid to these apphications of force while I remain free to question their legal or moral correctness.

Skepticism of this kind is perhaps more strongly felt by a crimmal suspect than by members of the general public, but its experience is not so himited. Americans have a profound and historic distrust for the use of governmental coercive power through the criminal process, ${ }^{43}$ and this perspective cannot be dismissed as an artifact of the eighteenth century. Because of the umique force and stigma of the criminal sanction, it is essential that we retain an alert skepticism regarding the perfection of our criminal laws and procedures. This is not to suggest that we presume the states' moral incorrectness in criminal cases; it requires only that we ensure an enclave for doubt, rather than arrogant certainty, regarding the correctness of the state's action when it prosecutes one of its citizens. Certainly, we should allow the suspect to hold and express such skepticisin when caught up in the criminal process.

Our history and present laws provide abundant reasons to preserve a place for inoral skepticism in every criminal case. For one thing, it is not unknown for our society to treat certain conduct as a criminal offense in one era, only to pronounce a different or opposite judgment in another time. ${ }^{44}$ The transitory nature of societal judgments about crime suggests

43. See Duncan v. Louisiana, 391 U.S. 145, 154, 155-56 (1968); LEVY, supra note 39, at 431; Herbert L. Packer, The Limits of the Criminal Sanction 170-71 (1968).

44. Prohibition and the criminalization of abortion are two examples. The Fugitive Slave Act, enforced in northern states during the ante-bellum period, is another. See JAMES M. MCPHERSON, BAtTle CRY OF Frbedom: The CIVIL WAR ERA 78-91, 119-21 (1988). The criminal laws applying to blacks and slaves in the American South, both before and after the Civil War, are by themselves encyclopedic documentation of the need for skepticism toward the correctness of criminal law. See McCleskey v. Kemp, 481 U.S. 279, 328-34 (1987) (Brennan, J., dissenting); A. LEON HigGINbotham, JR., IN the Matter of Color: RACE IN THE AMERican Legal Process (1978).

It is not hard to find criminal laws currently in force that are open to substantial moral question. See, e.g., Bowers v. Hardwick, 478 U.S. 186 (1986). The so-called "war on drngs," which 
that an individual who is guilty of an offense under current law might well question the justness of the result if he is duly convicted and punished.

Even in settings where we might expect universal agreement concerning the necessity to criminalize and to prosecute certain behavior, a space for moral skepticism remains. Most would acknowledge that aggravated homicide requires a criminal sanction. Many, however, question the use of capital punishment for such offenders and the nioral standing of any system that can produce this result.45 Similarly, for less serious crimes and punishments, we niay admit of doubt concerning the extent of our present use of incarceration for a wide array of offenses. ${ }^{46}$ Agam, even if we feel sure that the crime at issue should be punished, we may hold diverse views of the just consequence for the offender. Because of such uncertainties, we permit the offender the right to abstain from the process that leads to the punishment currently prescribed.

It is this sentiment, I believe, that has been voiced by the Suprenie Court and other defenders of the self-mcrimination privilege when they have described the privilege as carving out a "fair relationship" between individual and state. ${ }^{47}$ Although government niust have the power to set down criminal laws and to enforce them, it does not follow that government should also be enipowered to compel the individual to surrender his noral skepticisnı, and to jom through the active self-harm of testimonial cooperation in the very process he is permitted to doubt.

occupies a major share of the criminal docket, is challenged by some as an undue interference with individual liberty. See David Corcoran, Legalizing Drugs: Failures Spur Debate, N.Y. TIMES, Nov. 27, 1989, at A15. A defendant aceused of selling marijuana, for example, might feel moral ambivalence toward a system that seeks to punish him while sparing those who sell alcohol or tobacco. Others have criticized the war on drugs as in large part a racial conflict. See John A. Powell and Eileen B. Hershenov, Hostage to the Drug War: The National Purse, the Constitution and the Black Community, 24 U.C. DAvis L. REv. 557, 610-14 (1991); Ron Harris, Blacks Feel Brunt of Drug War, L.A. Times, Apr. 22, 1990, at A1.

45. See, e.g., Furman v. Georgia, 408 U.S. 238, 360 (1972) (Marshall, J., concurring); HuGo Bedau, DeAth Is DifFerent 245-46 (1987).

46. See American Bar Association, Standards for Criminal Justice Standard 182.5(b) (1979) [hereinafter STANDARDS FOR CRIMINAL JUSTICE] (“[M]any sentences authorized by statute in this country are, by comparison to other countries and in terms of the needs of the public, excessively long for the vast majority of cases."); see also id. Standards 18-2.1(e), 18-2.5(b)(i).

47. See In re Gault, 387 U.S. 1, 47 (1967); Miranda v. Arizona, 384 U.S. 436, 460 (1966); Murphy v. Waterfront Comm'n, 378 U.S. 52, 55 (1964). 


\section{Counsel's Obligations to Come Forward With} INCRIMINATING EVIDENCE IN THE ABSENCE OF A SPECIFIC LEGAL COMMAND

\section{A. The Olwell Line of Cases}

Since the 1960s a number of courts, beginning with State $v$. Olwell, ${ }^{48}$ have endorsed the view that a defense lawyer must come forward on her own initiative with evidence in her possession that incriminates her chent, and produce that evidence to a prosecutor. ${ }^{49}$ The "Olwell rule" can be seen as an extreme departure from the rights of passivity afforded to criminal suspects. Under the Fifth Amendment, the suspect hinself could not be required, even under legal compulsion, to coine forward with evidence where the act of production would supply incriminating information to the government. ${ }^{\text {so }}$ Certainly the law inposes no self-activating duty on the suspect to do so. Yet defense lawyers are told that they must come forward, in the absence of a government request or command, to give the prosecution active and testimonial assistance that their chents would not be expected to provide.

What follows in this Part is a close study of the Olwell rule, its internal mechanisins, and its imternal inconsistencies. I will suggest that the rule, although generally given broad statement in appellate court opinions, suffers from two nuajor defects. First, its apparent breadth is not supported by a close study of its purported legal bases. Second, and paradoxically, the scope of the rule has been strangely limited by the courts' total failure to apply it to documentary evidence in white-collar criminal

\section{394 P.2d 681 (Wash. 1964).}

49. In addition to Olwell, Morrell, and Meredith, discussed infra in text, the following courts have adopted or endorsed Olwell's self-activating duty: Clutchette v. Rushen, 770 F.2d 1469, 1472 (9th Cir. 1985); Hitch v. Pima County Superior Court, 708 P.2d 72, 75, 78 (Ariz. 1985); People v. Lee, 83 Cal. Rptr. 715, 722 (Ct. App. 1970); Anderson v. State, 297 So. 2d 871, 875 (Fla. App. 1974); Williams v. State, 368 S.E.2d 742, 747 (Ga. 1988); People v. Nash, 341 N.W.2d 439, 448 (Mich. 1983); In re Search Warrant (Gartley), 521 A.2d 422, 429 (Pa. 1987); Commonwealth v. Stenhach, 514 A.2d 114, 119 (Pa. Super. 1986). Some courts have taken issue with portions of Olwell's reasoming. See, e.g., Hitch, 708 P.2d at 72; State v. Superior Court, 625 P.2d 316 (Ariz. 1981). See generally Bender, supra note 12; Stephanie J. Frye, Disclosure of Incriminating Physical Evidence: The Defense Attorney's Dilemma, 52 U. Colo. L. REv. 419 (1981); Jane M. Graffeo, Ethics, Law, and Loyalty: The Attomey's Duty to Turn Over Incriminating Physical Evidence, 32 StAN. L. REV. 977 (1980); Lefstein, supra note 12; Barry S. Martin, Incriminating Criminal Evidence: Practical Solutions, 15 PAC. L.J. 807 (1984); David E. Seidelson, The Attorney-Client Privilege and Client's Constitutional Rights, 6 HofsTRA L. Rev. 693 (1978); Donald W. Stevenson, The Problem of an Attorney in Possession of Evidence Incriminating to His Client: The Need for a Predictable Standard, 47 CrN. L. REv. 431 (1978); Comment, The Right of a Criminal Defense Attorney to Withhold Physical Evidence Received from His Client, 38 U. CH. L. REv. 211 (1970).

50. See supra Part I(A); infra Part III(A)(2). 
cases. Both of these defects suggest that we have or should have a discomfiture with Olwell's command that defense counsel must breach the rights of passivity enjoyed by their chents.

The Fifth Amendment will be mentioned infrequently in Part II. One startling fact about the Olwell decision and its progeny is that they treat self-mcrimination concerns as wholly irrelevant to the question of how defense counsel can be made to behave. Part II seeks to understand Olwell on its own terms, and thus the Fifth Amendment will remain temporarily in the background. Part III, however, raises serious questions concerning Olwell's validity under existing passivity law. Part IV then presents a further attack upon the Olwell rule based upon the law of selfincrimination as it should be.

1. State v. Olwell. Olwell arose from a coroner's inquest followmg the homicide of Jolın Warren, who died of knife wounds. David Olwell, an attorney, represented Henry LeRoy Gray, the prime suspect in Warren's death. ${ }^{51}$ Several days before the inquest, Olwell was served with a subpoena ordering him to appear and "bring with you all knives in your possession and under your control relating to Henry LeRoy Gray ... or Jolın W. Warren."s2 Olwell, who im fact had a knife received from Gray, refused to produce it to the coroner or answer any questions about it. He declined at the inquest even to admit possession, although he answered a hypothetical question by saying that, if he did have a knife, he had received it in his capacity as attorney for Gray. ${ }^{53}$ Ultimately, the lawyer was held in contempt. ${ }^{54}$

On appeal to the Washington Supreme Court, Olwell argued two grounds for invalidating the coroner's subpoena. First, he contended that the attorney-client privilege barred compliance with the subpoena's terins and, second, that comphance would violate the chent's Fifth Amendment privilege. The court devoted the bulk of its attention to the attorney-chent privilege, codified by statute in Washington..$^{55}$ For purposes of its decision, the court assumed that Olwell had secured possession of the knife "through a confidential communication from his

51. Olwell, 394 P.2d at 682 . Indeed, Gray lad given the Seattle police a confession prior to retaining Olwell. Id.

52. Id. (emphasis added).

53. Id.

54. Olwell was ordered to spend two days in jail by the Superior Court of King County after failing to meet a 10-day deadline to purge himself of contempt. Id. at 683.

55. The Washington statute provided in relevant part: "An attorney or counselor shall not, withont the consent of his client, be examined as to any communication made by the client to him, or his advice given thereon in the course of professional employment." WASH. REV. CODE $\$ 5.60 .060(2)$ (1963). In the Olwell court's analysis, a plysical object could itself be privileged if it 
chent."56 Therefore, the court held that the privilege attached to the weapon and that the subpoena ordering its production was invalid. ${ }^{57}$

The court did not stop there, however. Instead, it announced a second ruling that erased the import of the first. ${ }^{58}$ Although the subpoena was unenforceable, Olwell could not withhold the evidence "indefinitely." Rather, the lawyer had a duty to turn over the knife to the authorities on his own notion, in the absence of any specific legal command to do so, after "a reasonable period of time" necessary to examine it for purposes of preparing a defense..$^{59}$ More broadly, the court said that an "attorney should not be a depository for criminal evidence":60 "[T]he attorney, after a reasonable period, should, as an officer of the court, on his own motion, turn the [criminal evidence] over to the prosecution."61 The court did not cite statutes, ethical canons, or prior precedent for its conclusion that an exception to the attorney-chent privilege was required.

The Olwell court recognized that its announced rule might threaten the attorney-chent relationship by reducing the client's sense of assurance that inforination supplied to counsel would remain confidential. The court said, however, that the attorney-chent privilege could be "preserved" through a limitation upon the proof allowed at trial following production of physical evidence by defense counsel.62 Specifically, the court said that the government, after introducing such evidence at trial, should not be allowed to inforn the jury that defense counsel had been

was delivered to counsel by the chient or if counsel's possession was the "direct result" of confidential information supplied by the chent. The court said that an object itself could be thought of as a "privileged communication." 394 P.2d at 683. This portion of Olwell is outnoded. It is generally recognized today that a pre-existing physical object cannot itself be a "conımunication" protected by the attorney-client privilege, but that the client's act of delivery to the lawyer may itself be communicative and confidential. See, eg., Morrell v. State, 575 P.2d 1200, 1208 (Alaska 1978); People v. Lee, 83 Cal. Rptr. 715, 722 (Ct. App. 1970); Anderson v. State, 297 So. 2d 871, 872-73, 875 (Fla. App. 1974).

56. Olwell, 394 P.2d at 683. Although there was no direct evidence regarding the way in which Olwell had gained possession of the knife, the court thought it "reasonable to infer" that the source was the client. Id.

57. The subpoena's command that Olwell produce client-source evidence in open hearing, in the court's view, was "tantamount to requiring the attorney to testify against the client without the latter's consent." Id. at 684.

58. This second ruling was techmically dictun as it was unnecessary to the court's decision. See Lefstein, supra note 12, at 916.

59. Olwell, $394 \mathrm{P} .2 \mathrm{~d}$ at $684-85$.

60. Id. at 684. It is not altogether clear what the Olwell court meant by the phrase "criminal evidence," although the court gave the examples of "a knife, other weapons, stolen property, etc." Id. The court suggested that this type of evidence "in itself has little, if any, material value for the purposes of aiding counsel in the preparation of the defense in his client's case." Id.

61. Id. at $684-85$.

62. Id. at 685 . 
the source of the evidence, and intimated that violation of this prohibition would be reversible error. ${ }^{63}$ The government would be barred from asserting at trial that "we received this knife from the defense," but not froin proving through other means that the weapon belonged to the defendant. 64

Having disposed of issues surrounding the attorney-chent privilege, Olwell's Fifth Amendment argument barely detained the court and was dismissed in the closing paragraphs of its opinion. Olwell had based his Fifth Amendment claim upon a passage from Dean Wigmore's evidence treatise stating that counsel should not be bound to produce evidence that would have been privileged in the hands of the chent. ${ }^{65}$ The court rejected this proposition with hittle discussion of its merits, noting that it was not the "standard answer" to the question at hand. ${ }^{66}$ Instead, the court looked to cases holding that the self-incrimination protection "is personal to the chent and must be claimed by the chient alone."67 Under this authority, the court held that the lawyer was precluded from asserting his chent's self-incrimination privilege.

2. Morrell v. State. Olwell received an important reexamination and extension in the Alaska case of Morrell v. State, ${ }^{68}$ which adopted the Olwell rule, gave careful study to its legal bases, and ultiniately apphed the rule to an incriminating document. ${ }^{69}$ Clayton Morrell was charged with the kidnapping, assault, and multiple rapes of an eighteen year old victin over an eight-day period. ${ }^{70}$ Following Morrell's arrest, Stephen

63. See id. Later decisions in the Olwell line of cases have generally endorsed this rule. See, e.g., Hitch v. Pima County Superior Court, 708 P.2d 72, 79 (Ariz. 1985); People v. Meredith, 631 P.2d 46, 54 n.8 (Cal. 1981); Anderson v. State, 297 So. 2d 871, 875 (Fla. App. 1974); Williams v. State, 368 S.E.2d 742, 747 (Ga. 1988). The rule of exclusion does not operate when the attorney discloses evidence that she has received not from the chent, but from a third party. See Morrell $v$. State, 575 P.2d 1200, 1208-09 (Alaska 1978); People v. Lee, 83 Cal. Rptr. 715, 723 (Ct. App. 1970).

64. The court expressed no limitation upon the out-of-court use that the government could make of its knowledge that the defense attorney had produced the knife in further investigation of the case. In the Olwell cases as a whole, there is no analog to the derivative use protections required when use immunity is granted. See infra Part III(A)(3).

65. See Olwell, 394 P.2d at 685 (quoting 8 JOHN HeNRY WIGMORE, EvidENCE $§ 2307$, at 592 (John T. McNaughton rev. ed., 1961)) ("It follows, then, that when the client himself would be privileged from production of the document, either as a party at common law or as a third person claiming title or as exempt from self-incrimination, the attorney having possession of the document is not bound to produce.").

66. Id.

67. Id. at 686 (citing cases).

68. 575 P.2d 1200 (Alaska 1978).

69. Following Morrell, other courts have also held or opined that the Olwell rule extends to documentary evidence. See, e.g., Clutchette v. Rushen, 770 F.2d I469, 1472 (9th Cir. 1985); In re Search Warrant (Gartley), 521 A.2d 422, 429 (Pa. 1987).

70. Morrell, 575 P.2d at 1202. 
Cline of the Public Defender Agency was appointed to represent him. About a month later, Cline was contacted by Jolin Wagner, a friend of Morrell's. At Morrell's suggestion, Wagner had cleaned out one of Morrell's cars and had discovered a legal pad containing what appeared to be a written kidnap plan. Wagner asked Cline to meet him and take possession of the document, which Cline did. ${ }^{71}$ Cline then talked with his client. Morrell claimed the plan was unrelated to the charged offense, and that he had sketched it in response to an earher kidnapping reported on television. ${ }^{72}$

Cline, uncomfortable with his possession of the document, requested an advisory opinion from the Ethics Committee of the Alaska Bar Association. The committee orally advised him to give the plan back to Wagner after educating Wagner about Alaska's concealınent of evidence law. The committee also advised Cline that he should resign from the case "if it later became obvious to him that an ethical violation would result" from his continumg representation of Morrell..$^{73} \mathrm{~A}$ formal opinion later adopted by the committee stated that Cline had an ethical obhigation not to reveal the existence of physical evidence to the authorities "unless required to do so by statute."74

After receiving the committee's oral advice, Cline decided that he would return the plan to Wagner, and he resigned as Morrell's counsel. ${ }^{75}$ A few days after withdrawing from the case, Cline met with Wagner and the state pohice. Cline returned the kidnap plan to Wagner, who immediately gave it to the troopers. ${ }^{76}$ Ultimately, the docuinent was introduced as evidence at Morrell's trial. In addition, Cline was called as a witness agamst his former chent and recounted his transactions with Wagner concerning the plan. ${ }^{77}$ Morrell was convicted on all counts. ${ }^{78}$

The Alaska Supreme Court heard Morrell on a claim that Cline's conduct contributing to the production of the kidnap plan had denied Morrell his constitutional right to the effective assistance of counsel. ${ }^{79}$

71. Id. at 1206.

72. $I d$.

73. $I d$.

74. Id. at 1211. The usefulness of this thought, however, was watered down by the committee's refusal to render an opinion concerning the applicability of Alaska's concealment of evidence statute, or any other state law. See id.

75. Id. at 1206.

76. Id. at 1207.

77. The Morrell court found that receipt of Cline's testimony was proper, because it related to events between Cline and a nonclient, and thus fell outside the protections of the attorney-client privilege. Id. at 1211 n.17.

78. Id. at 1202.

79. Id. at 1206-07. As a remedy, Morrell claimed the plan should have been suppressed at trial. Id. at 1207. 
At the time, such claims were analyzed in Alaska under both state and federal constitutional guarantees. ${ }^{80}$ The relevant standard was whether Cline's conduct in representing Morrell was "within the range of reasonable actions which might have been taken by an attorney skilled in the criminal law."81

The court rejected Morrell's ineffectiveness claim, not on the narrow ground that Cline's actions had been within the range of professionally reasonable conduct, but with the inore aggressive assertion that Cline had been obligated to see that the kidnap plan reached the hands of the prosecutor. ${ }^{82}$ Relying first on Olwell and its progeny, the court said that Cline's obligation to produce the document on his own motion would have existed even if he had received the evidence directly from his client. ${ }^{83}$ The Morrell court articulated its understanding of the Olwell rule in broad terms: "[A] criminal defense attorney inust turn over to the prosecution real evidence that the attorney obtains froin his chent. . . . [I]t would constitute unethical conduct for an attorney-an officer of the court-to knowingly fail to reveal relevant evidence in a criminal case." 84 The attorney's duty to coine forward was "even clearer" here, however, because he was dealing with evidence received from a non-chent that had no claim to protection under the attorney-client privilege. In addition, because such non-chent-source evidence was at issue, the court held that there was no bar at trial to Cline's testimiony regarding the events that led to his possession of the plan and its production to the authorities. Olwell's exclusion of such evidence would not be followed. ${ }^{85}$

The Morrell court rested its decision im part on Olwell and subsequent cases dealing with such "dramatic" physical evidence ${ }^{86}$ as bloodstained shoes worn by the accused, ${ }^{87}$ a sawed-off shotgun used in an armed robbery, ${ }^{88}$ and rings taken from the victim of a inurder. ${ }^{89}$ No

80. See Risher v. State, 523 P.2d 421 (Alaska 1974).

81. Id. at 424. The Risher court recognized that different lawyers might handle a given problein in varying ways: "Lawyers may display a wide spectrum of ability and still have their performance fall within the range of coinpetence displayed by one of ordinary training and skill in the crininal law." Id.

82. See Morrell, 575 P.2d at $1210-11$.

83. See id. at 1207,1211 .

84. Id. at $1210-11$.

85. See id. at 1211 n.17; accord People v. Lee, 83 Cal. Rptr. 715, 723 (Ct. App. 1970).

86. See infra Part $1 \mathrm{I}(\mathrm{C})(2)$ for a discussion of the ineaning of the term "dramatic" physical evidence, as potentially distinguishable from physical evidence that is not "drainatic." I will suggest that such a distinction is not one the law should attempt to inake.

87. See Lee, 83 Cal. Rptr. at 722.

88. See In re Ryder, 263 F. Supp. 360, 362, 369 (E.D. Va.), aff'd, 381 F.2d 713 (4th Cir. 1967).

89. See Dyas v. State, 539 S.W.2d 251 (Ark. 1976). 
Olwell case prior to Morrell had involved a document. The court, however, saw no reason not to extend the Olwell decision and its progeny to an incriminating document such as the kidnap plan: "[W]e think that no distmction should be drawn in the privilege context between physical evidence obtained by a criminal defense attorney which is 'mere evidence' of a chent's crime and that which may be said to be either a fruit or an instrumentality of the crime." 90 The court thus concluded that defense counsel must turn over all "relevant evidence in a criminal case," with no qualification concerning the nature of the evidence. ${ }^{91}$

The court's authority for its expansion of Olwell was Warden v. Hayden, ${ }^{92}$ a Fourth Amendment case that abohished the distinction between "inere evidence" and "fruits or instrumentalities" of crime under search and seizure law. ${ }^{93}$ Warden did not concern the production of evidence by defense counsel, but held generally that search warrants could issue for all kinds of physical evidence, overruling the prior, propertybased view that only the fruits and mstrumentalities of crime could be seized by the goverument. ${ }^{94}$ Along the way, the Warden Court belittled the old rule and the idea that "mere evidence" was distinguishable from "fruits and instrumentalities" of crime as archaic and "wholly irrational."9s The Morrell court drew force froin Warden's forceful, cominon-sense view that property-based distinctions among forms of evidence in a criminal case were not viable. ${ }^{96}$ Accordingly, the Morrell court conld see no rationale for limiting the scope of the Olwell rule only to some types of evidence, while excluding mcriminating documents.

In addition to its rehance on prior Olwell cases, the Morrell court also found support for its holding in Alaska's statutes and conduct rules. The state ethics committee, it will be remembered, had concluded that Cline had an ethical duty not to reveal the existence of the kidnap plan

90. Morrell, 575 P.2d at 1209 (footnote omitted).

91. See id. at 1211.

92. 387 U.S. 294 (1967).

93. See id. at 301-02.

94. The prevailing view prior to Warden was that certain property was subject to seizure by the government because the person in possession did not have rightful ownership, as with stolen goods, or had forfeited his interest in it by using the property in connection with a criminal act. Other tangible things that were not similarly tainted were thought beyond the reach of the seizurc power. See id. at 303-04.

95. Id. at 302.

96. This is not to say that all plysical evidence is or should be treated identically by the law. There are some categories of things, such as contraband and stolen property, whose possession is criminalized quite apart from any evidentiary value they may have in a criminal prosecution. $C f$. In $r e$ January 1976 Grand Jury (Genson), 534 F.2d 719, 727 (7th Cir. 1976) (opinion of Pell, J.) (stating that Fifth Amendment's operation may be different in case where lawyer possesses "fruits of a violent crime" as opposed to "tax records or work papers" relevant to a criminal tax investigation). See infra Part II(B)(2). 
"unless required to do so by statute." Assuming that statement to be correct, ${ }^{97}$ the court held that such a statutory command could arguably be found under Alaska's criminal code, in its concealment of evidence provision. ${ }^{98}$ If Clime would have been guilty of concealment of evidence if he had kept the kidnap plan, the court reasoned, then he had the professional duty to produce it. It is important to note, however, that the court did not find it necessary to render a definitive imterpretation of the concealment of evidence statute to decide the case before it. Because Morrell was an ineffectiveness case, the question was whether an attorney of ordmary skill could reasonably have concluded that retention of the plan would have been a criminal offense and thus a professional violation.

Alaska's concealment of evidence statute, like those in other states, required soine affirmative act of concealment beyond a inere failure to come forward with evidence before criminal hability would attach. ${ }^{99}$ In the view of the Morrell court, Clime might have crossed this line if he had kept the plan: "[T]aking possession of evidence from a non-chient third party and holding the evidence in a place not accessible to mvestigating authorities would seein to fall within the statute's ambit."100 Further, the court said that the mens rea required for the crime-an intent to prevent discovery or production of the evidence-would have been supportable if Cline had kept the plan because he "had no other possible

97. In this respect, the state ethics committee had faithfully reproduced the rule written into the Model Code of Professional Responsibility and later incorporated into the Model Rules of Professional Conduct. See MODEL CODE OF PROFESSIONAL ReSPONSIBILITY DR 7-102(A)(3) (1980) (prohibiting attorney's knowing failure to disclose "that which he is required by law to reveal"); id. EC 7-27 (" $[\mathrm{A}]$ lawyer should not suppress evidence that he or his client has a legal obligation to reveal or produce."); Model RULES OF Professional Conduct Rule $1.6 \mathrm{cmt}$. 5 (1983) ("A lawyer shall not disclose [information relating to the representation of a client] except as authorized by the Rules of Professional Conduct or otler law."); id. cmt. 20 ("[A] lawyer may be obligated or permitted by other provisions of law to give information about a chient. Whetler another provision of law supersedes Rule 1.6 is a matter of interpretation beyond the scope of these Rules, but a presumption should exist against such supersession."). See also AMERICAN Bar Association STANDARDS For CRIMinal Justice Standard 44.6 (1991) (stating that lawyer should disclose client-incriminating plysieal evidence received by lawyer "if required by law or court order").

98. At the time of the Morrell decision, Alaska law provided:

Destroying, altering or concealing evidence. A person who willfully destroys, alters or conceals evidence concerning the commission of a crime or evidence which is being sought for production durimg an investigation, inquiry or trial, with the intent to prevent the evidence from being discovered or produced, is guilty of a misdemeanor and upon conviction is purishable by miprisonment for not more than one year, or by a fine of not inore than $\$ 1,000$, or by both.

ALASKA STAT. § 11.30 .315 (1970).

99. This was the view taken by the Morrell court itself. See Morrell, $575 \mathrm{P} .2 \mathrm{~d}$ at 1212 . For a discussion of related statutes, see infra Part II(B)(1).

100. Morrell, 575 P.2d at 1212. 
reason for taking and retaining possession of the evidence."101 Thus, the court ruled that Cline had not provided ineffective assistance to Morrell because he could reasonably have concluded that failure to produce the plan would have been not only a violation of the Olwell rule, but a criminal offense, as well. ${ }^{102}$

3. People v. Meredith. Aside froin Morrell, the most significant developinent in the evolution of the Olwell rule came in the Cahifornia case of People v. Meredith, ${ }^{103}$ authored by Justice Tobriner in 1981. Meredith arose froin the first degree murder convictions of co-conspirators Michael Meredith and Frank Scott. About a month after the crime, Scott told his appointed lawyer, James Schenk, that he had had possession of a wallet belonging to the victin, had tried but failed to burn it, and had disposed of it in a garbage can behind his house. ${ }^{104}$ Schenk sent a defense investigator, Steven Frick, to retrieve the wallet, which Frick did. Schenk examined the wallet, which contained credit cards belonging to the victinl, and turned it over to the police. ${ }^{105}$

By the time of trial, Scott had obtained new counsel. The defense did not challenge Schenk's earher production of the wallet as inproper, and conceded that the wallet itself was admissible at trial.106 Over Scott's objection, however, the government was allowed to call defense investigator Frick to identify the wallet and testify that he had found it in a garbage can behind Scott's residence. The defense, appealing froin this ruling, clainied that Frick's testiniony had revealed confidences protected by the attorney-chent privilege.

The court agreed that Frick's testiniony regarding the wallet ordinarily would fall within the attorney-chent privilege because his observations of the wallet were "made as a consequence of protected

101. Id. at 1212 n.22.

102. See id. at 1212 n.23. As an effectiveness case, Morrell is peculiar in the following sense: It is odd to think that the scope of a constitutional guarantee slould be dictated by the terms of a state statute. It is odder still that a constitutional guarantee may be limited by every "reasonable" interpretations the statute might be given. On this point, Commonwealth v. Stenliach, 514 A.2d 114 (Pa. Super. Ct. 1986), arrives at the opposite conclusion, holding that the terms of a state's criminal laws on the production of evidence by defense lawyers must be himited to conform to constitutional guarantees. See id. at 124-27.

103. 631 P.2d 46 (Cal. 1981). Eleven years prior to Meredith, the California Court of Appeals had adopted the Olwell rule in People v. Lee, 83 Cal. Rptr. 715 (Ct. App. 1970).

104. Meredith, 631 P.2d at 49.

105. Schenk's plan at the time was to tell the poliee only that, to the best of his knowledge, the wallet had belonged to the victim. Id. . Both Schenk and his investigator Frick were subpoenaed to testify at Scott's preliminary hearing. Sclienk, when threatened with contempt, revealed that his sole source of information regarding the wallet's location had been his client. Frick, over Sclienk's objection, testified that lie liad found the wallet in a garbage can behind Scott's residence. Id. at 49-50. 106. Id. at 48 . 
communications" between Schenk and Scott. ${ }^{107}$ Even so, the court found application of Olwell's rule of exclusion inappropriate. ${ }^{108}$ In removing the wallet froin the trash can behind Scott's residence, the court reasoned, the defense had deprived the government of the opportuinty of discovering the evidence in that exact location. In so doing, the defense liad in effect "destroyed" critical information: "[I]t is as if ... the wallet in this case bore a tag bearing the words located in the trash can by Scott's residence,' and the defense, by taking the wallet, destroyed this tag." 109 To avoid the loss of such contextual inforination, the court concluded that there should be an exception to the attorney-client privilege "in cases in which counsel [or a defense investigator] has reinoved or altered evidence." 110 In such circumstances, the government would be allowed to introduce evidence at trial to recreate the contextual facts that had been obscured by counsel's removal or alteration. ${ }^{111}$

The Meredith court suggested that defense counsel could avoid the harmful effects of its ruling upon their chents simply by electing not to reinove physical evidence froin its original location. ${ }^{112}$ It is only when the defense inoves or alters evidence that the full protection of the attorney-chent privilege is lost. ${ }^{113}$ In the same breatl, however, the court recognized that counsel will sometimes find it necessary to take possession

107. Id. at 52. To reach this conclusion, the court ruled that California's attorney-chent privilege reached beyond actual communications between lawyer and chent to include observations that result from such communications. Id. at 50-52.

108. See id. (quoting Olwell, 394 P.2d at 685).

109. Id. at 53; see also In re Ryder, 263 F. Supp. 360, 362, 369 (E.D. Va.), aff'd, 381 F.2d 713 (4th Cir. 1967). In Ryder, the court found that a defense lawyer had intended to "destroy the chain of evidence" linking allegedly stolen cash and a shotgun with his client when he took these items from the chent's safety deposit box and put them into his own box. See id. at 362; see also id. at 369.

110. Meredith, 631 P.2d at 53. The court followed the accepted view that a defense investigator should be treated no differently than defense counsel. See id. at 50-51 n.3. See also In re Grand Jury Investigation, 556 N.E.2d 363, 365 (Mass. 1990) ("Turning meinbers of the defense team into government witnesses may undermine a chient's trust in, and his willinguess to communicate with, his attorney.").

111. Meredith, 631 P.2d at 54. The court suggested that, in most trials, such evidence could be received without informing the jury that the facts had first been conveyed to the government by the defense. This could be achieved, for example, by a stipulation that "simply inform[ed] the jury as to the relevant location or condition of the evidence in question." Id. at 54 n.8. At Scott's trial, Frick's testimony had been put in by the government without identifying him as a defense investigator. The court approved of this procedure as one way to avoid suggesting to the jury that the testinony was traceable back to a confidential communication made by the defendant. Id. By means of this kind, Olwell's rule of exclusion would not be bypassed entirely, but would be diluted to the extent necessary to allow for the reconstruction of lost contextual information.

112. See id. at 53 n.7; see also Standards for CRIMinal Justice, supra note 97, Standard 4 4.6(b), (c) (expressing a general preference, with exceptions, that "defense counsel should return the itein to the source from whom defense counsel received it"); Bender, supra note 12, at 892 (advocating a "look but don't touch" rule).

113. The Meredith court stated: 
of physical evidence to study it, and that examination at the scene may not be satisfactory for this purpose. ${ }^{114}$ In such cases the attorney does not act improperly in taking possession, the court said, but under Olwell, she must turn it over to the prosecution within a reasonable time after taking possession. ${ }^{115}$

4. Summary. The inajor precepts of the "Olwell rule," as extracted from Olwell and the decisions in its wake, can be summarized into four basic principles: (1) Defense counsel inust, on her own initiative, produce physical evidence in her possession that imcriminates her chent; (2) this self-activating duty is important enough to require disclosure of evidence and information otherwise protected by the attorney. chent privilege; (3) where the attorney-client privilege apphes, however, the government inay not reveal the source of the evidence at trial; and (4) production by counsel does not imphicate the client's Fifth Amendment passivity rights.

Morrell adds four important propositions to the Olwell rule: (1) Olwell inay be extended to chent-incriminating documents; (2) Olwell's rule of exclusion has no force in cases that concern nonclient-source evidence; (3) an attorney's failure to observe the Olwell rule may be a criminal offense; and (4) the constitutional guarantee of effective assistance of counsel is not offended when a defense lawyer produces evidence pursuant to the Olwell rule.

Finally, Meredith adds two significant points: (1) Olwell's rule of exclusion of evidence inay be bypassed to the extent necessary to recreate contextual facts lost when counsel inoves or alters evidence; and (2) the force of the Olwell rule can be avoided entirely if defense counsel does not alter or take possession of evidence.

\section{B. Legal Bases of the Olwell Rule}

One can search the Olwell opimion carefully, repeatedly, yet in vain for the legal bases of counsel's self-activatimg duty to disclose evidence to the government. ${ }^{116}$ Later courts, such as Morrell, have attempted to fill

We thus view the defense decision to remove evidence as a tactical choice. If defense counsel leaves the evidence where he discovers it, his observations derived from privileged commumications are insulated from revelation. If, however, counsel chooses to remove evidence to examine or test it, the original location and condition of that evidence loses the protection of the privilege.

631 P.2d at 54.

114. The examples given by the court included the need to take possession of a weapon to perform fingerprint or ballistics tests. See id. at 53 n.7.

115. See id. (citing Olwell, 394 P.2d at 684-85).

116. The Olwell court did say at oue point that the attomey's duties were those of an "officer of the court," but did not indicate whether such ideutification came from the rules of professional 
in this blank space and have posited that the Olwell duty derives from the coinbined force of rules of professional conduct and the criminal statutes of individual jurisdictions concerning such things as obstruction of justice and the possession of contraband. ${ }^{117}$

Within this interaction, conduct codes such as the Model Code of Professional Responsibility and the Model Rules of Professional Conduct play a himited role. The codes theinselves supply no substantive rules that mandate disclosure of evidence of past crimes by defense counsel; ${ }^{118}$ they inerely incorporate disclosure duties found elsewhere im the law. For example, the Model Code states that "a lawyer shall not ... conceal or knowingly fail to disclose that which he is required by law to reveal." 19 The Model Rules adopt the same approach and specify that laws thought to create a disclosure duty should be narrowly construed. ${ }^{120}$ In general, of course, both the Model Code and Model Rules provide that an attorney has an ethical duty not to divulge evidence or information acquired in the course of the representation. ${ }^{121}$

To date, the substantive laws incorporated into the conduct rules, assertedly giving rise to the Olwell duty, have all been criminal statutes. These in turn fall into two broad categories. First, some courts have referred to laws that concern such inatters as obstruction of justice, hindering prosecution, and concealment of evidence. ${ }^{122}$ I will refer to these

conduct, the court's supervisory powers over lawyers, the common law, or the statutory law. See Olwell, 394 P.2d at 684-85.

117. See, e.g., Morrell, 575 P.2d 1200, 1211-12; see also In re Ryder discussion, infra note 123.

118. The codes provide formulas for a lawyer's discretionary disclosure of a client's intention to coinunit a crime in the future. See Model Code of Professional Responsibility DR 4 $101(C)(3)(1980)$ (permitting a lawyer to reveal "[t]he intention of his chient to commit a crime and the information necessary to prevent the crime"); MODEL RULES OF Professional CONDUCT Rule 1.6(b)(1) (1983) ("A lawyer may reveal such information to the extent the lawyer reasonably believes necessary ... to prevent the client from committing a criminal act that the lawyer believes is likely to result in imminent death or substantial bodily harm.").

119. MODEl CODE OF PROFEssional REsponsibility DR 7-102(A)(3) (1980) (einphasis added).

120. See Model Rules of Professional Conduct Rule $1.6 \mathrm{cnt}$. 5 (1988) (“A lawyer shall not disclose [information relating to the representation of a chient] except as authorized or required by the Rules of Professional Conduct or other law."); id. cmt. 20 ("[A] lawyer may be obligated or permitted by other provisions of law to give information about a chient. Whether another provision of law supersedes Rule 1.6 is a matter of interpretation beyond the scope of these Rules, but a presumption slrould exist against such supersession.”).

121. See Model Code of Professional Responsibility DR 4-101 (1980); MOdel RULes of Professional Conduct Rule 1.6 (1988). Improper disclosure by a lawyer is a ground for professional discipline. See In re Rhame, 416 N.E.2d 823 (Ind. 1981); In re James M. Pool, No. 8387 BD (Mass. Jan. 17, 1984).

122. See Morrell, 575 P.2d at 1200. A recent Pemisylvania prosecution and disciplinary proceeding addressed the claim that two defense attorneys had violated state statutes that proscribed tampering with evidence and himdering prosecution when they took possession of evidence. See Commonwealth v. Stenhach, 514 A.2d 114 (Pa. Super. Ct. 1986) (criminal prosecution); Office of 
collectively as "obstruction" laws. Second, some Olwell decisions have relied upon statutes that criminalize the possession of contraband. ${ }^{123}$ These I will call "contraband" laws. No court has yet cited a substantive civil law basis for the self-activating Olwell duty. ${ }^{124}$

If the above précis of Olwell's legal basis is correct, then the term "Olwell rule" is a misnomer. There is no independent rule emanating from Olwell itself that requires defense lawyers to come forward with evidence. Sucl a requirement, if it exists, originates wholly in the criminal statute books. The Olwell rule simply restates the proposition that the criminal code applies to criminal defense lawyers. It adds nothing to the accepted view that attorneys are not permitted to coinmit crimes in the representation of their clients, and that sucli criminal conduct will not be shielded by the confidentiality otherwise extended to the attorneyclient relationship..$^{125}$

By this reasoning, counsel's obligation to disclose evidence on her own mitiative arises only, if at all, where the legislature and courts would

Disciplinary Counsel v. Stenhach, Pa. Super. Ct. Disciplinary Bd., No. 479, Disc. Docket No. 2 (Super. Ct. Aug. 8, 1989) (disciplinary proceeding). The defense lawyers prevailed in both proceedings. In addition to criminal statutes expressly concerned with obstruction of justice and the concealment of evidence, defense lawyers inay also be subject to criminal liability as accessories after the fact for conduct designed to conceal the criminality of a client. See State ex rel. Okla. Bar Ass'n v. Harlton, 669 P.2d 774 (Okla. 1983) (disciplinary proceeding following attorney's guilty plea to accessory after the fact charges under federal law for concealing a shotgun with intent to hinder prosecution).

123. In the famous case of $I n$ re Ryder, 263 F. Supp. 360 (E.D. Va.), aff'd, 381 F.2d 713 (4th Cir. 1967), the court imposed disciplinary sanctions on a defense lawyer who had taken custody of evidence. The court concluded that he had violated state and federal laws concerning the possession of contraband. Ryder was a disciplimary proceeding to determine whether a lawyer should be removed from practice before the federal district court due to his conduct as defense counsel in an armed robbery case. Five days after the robbery, Ryder had taken cash and a sawed-off shotgun from his chent's safety deposit box and moved it to his own safety deposit box. The court analyzed Ryder's conduct under the ABA Canons of Professional Ethics, then in force in Virginia, and under the criminal codes of Virginia and the United States. It found that the Canons instructed attorneys to render their services "within and not without the bounds of the law" and to "observe the statute law." Id. at 368-69 (quoting ABA Canons of Professional Ethics Canons 15, 32 (1908)). The substantive law applicable to this lawyer's conduct, the court held, included Virginia's criminal statute regarding the receipt of stolen property, VA. CODE ANN. \$ 18.1-107 (Michie 1950), and 26 U.S.C. $\$ 5851$ (1964), which criminalized receipt and possession of the sawed-off shotgun. Because Ryder's conduct was in contravention of these criminal laws, the court found a violation of the ethical canons and suspended him from practice for 18 months. Ryder, 263 F. Supp. at 370.

124. This is not to say that it is impossible to imagine civil obligations concerning the handling of evidence that could be used in support of an Olwell case. See Smith v. Superior Court, $198 \mathrm{Cal}$. Rptr. 829 (Ct. App. 1984) (recognizing new tort of "intentional spoilation of evidence" where defendant in personal injury case allegedly destroyed physical evidence of automobile accident after plaintiff's counsel had alerted defendant to the fact that the evidence could be relevant to the plaintiff's claims); Hazen v. Municipality of Anchorage, 718 P.2d 456 (Alaska 1986) (following Smith).

125. These are old propositions, dating at least to the ABA Canon of Professional Ethics 32, adopted in 1908. 
be willing to punish her failure to do so with a criminal conviction. Such willingness has seldom been demonstrated. A review of statutes currently in force, and of judicial rulings in cases where lawyers have been prosecuted for failure to come forward with evidence, suggests that, except in the few cases involving contraband laws, the substantive criminal law bases for Olwell's self-activating duty are quite narrow and support few of the apphications of the Olwell rule that have been endorsed by the courts.

1. Obstruction Laws. Obstruction laws are most often proffered as the appropriate substantive law basis for the Olwell rule. This makes a degree of sense, as obstruction statutes are intended to ensure the availability of evidence and information to law enforcement agencies. Likewise, the Olwell rule is concerned with the evidentiary or informational value of the physical object or contextual information that defense counsel may be required to supply. ${ }^{126}$ Still, the elements of a typical obstruction law violation do not neatly fit the scenario of a lawyer who takes possession of evidence relating to the defense of a chent.

As the Morrell court recognized, a conviction for an obstruction offense usually requires "an affirmative act of concealment [of evidence] in addition to the failure to disclose information to the authorities."127 Ordimary laypersons are not called upon to come forward with physical evidence of crime in their possession, even if they could easily do so. They are not exposed to criminal hability until they engage in positive conduct that may hinder the government's efforts to detect crime or prosecute an offender. It is difficult to see why defense lawyers should be exposed to criminal liability for failure to produce evidence when an ordinary member of the public would not be. If anything, the obstruction laws should be apphed with less force to criminal defense lawyers domg their jobs than to the general citizenry. ${ }^{128}$

126. In contrast, the contraband statutes discussed infra in Part II(B)(2) do not focus on the evidentiary or informational value of contraband that counsel may be required to turn over to the government.

127. Morrell, 575 P.2d at 1212 (einphasis added) (citing Umited States v. Daddano, 432 F.2d 1119 (7th Cir. 1970), cert. denied, 402 U.S. 905 (1971)). This statement holds true for obstruction laws nationwide. See, e.g., 18 U.S.C. $\$ 4$ (1988) (requiring affirmative act of concealment for offense of misprision of felony); CaL. Penal CODE $\$ 135$ (West 1988) (requiring willful destruction or concealment for offense of destroying or concealing documentary evidence); ILL. ANN. STAT. ch. 38, para. 31-4 (Smith-Hurd 1977) (requiring destruction, alteration, concealment, or disguise of evidence for offense of obstruction of justice).

128. See Commonwealth v. Stenhach, 514 A.2d 114, 127 (Pa. Snper. Ct. 1986) (holding state hindering and tampering statutes nnconstitutionally overbroad because they failed to include clear exceptions for defense counsel); Clark v. State, 261 S.W.2d 339 (Tex. Crim. App.), cert. denied, 346 
The mens rea requirement of obstruction law is also problematic when applied to defense lawyers who take possession of physical evidence. The state of mind required for conviction is typically a purpose or specific intent to interfere with an official investigation or prosecution. ${ }^{129}$ Thus, even affirmative acts of concealment of evidence are not criminal if performed for some other reason. ${ }^{130}$ A defense lawyer who takes physical evidence for the purpose of furthering her investigation of the client's case, preparing a defense, or ensuring that the evidence is not destroyed, falls outside the reach of the obstruction laws. ${ }^{131}$

2. Contraband Laws Few Olwell cases arise under contraband laws, but those that do are more likely to spell trouble for defense counsel than Olwell cases based on obstruction statutes. In contrast to the concerns of obstruction law, the evidentiary or informational value of contraband to a government investigation is not the basis for a requirement that the lawyer come forward. Rather, the laws represent a legislative judgment that certain things, because of their character, should not be possessed by citizens at all.

Contraband offenses typically are defined in terms of possession of the illegal object or substance, together with some level of awareness concerning the nature of the thing possessed. ${ }^{132}$ The low-grade actus reus

U.S. 855 (1953) (construing statute explicitly excluding from liability one who aids an offender in preparing his defense).

129. See, e.g., Cal. Penal Code $\S 135$ (West 1988) (requiring intent to prevent evidence from being produced in any trial, inquiry, or investigation authorized by law for offense of destroying or concealing documentary evidence); ILL. ANN. STAT. ch. 38, para. 31-4 (Smith-Hurd 1977) (requiring intent to prevent the apprehension of or to obstruct the prosecution or defense of any person for offense of obstructing justice); MODEl PeNal CODE § 241.7(1) (requiring "purpose" of impairing the verity or availability of evidence in an official proceeding for offense of tampering); $i d$. 242.3 (requiring "purpose" to hinder a criminal investigation or prosecution for offense of hindering).

130. See United States v. King, 402 F.2d 694, 697 (finding misprision conviction inappropriate where defendant may have taken possession of stolen money for economic purpose rather than purpose of concealing crime).

131. See Hitch v. Pima County Superior Court, 708 P.2d 72, 76 n.2 (Ariz. 1985) (disagreeing with state ethics committee that attorney's failure to cone forward with victin's wristwatch would have constituted the offenses of tampering with physical evidence and hindering prosecution because lawyer took possession of evidenee to prevent its destruction and lacked necessary intent to make evidence unavailable for prosecution); STANDARDS FOR CRIMINAL JUSTICE, supra note 97, Standard 4-4.6(c) (stating that one pernissible reason that lawyer may accept possession of client-incriminating evidence is a reasonable fear "that return of the item to the source will result in destruction of the itein").

132. See, e.g., Colo. REv. STAT. $\S 18-12-102(3)$ (1986) (defining offense of possessing a dangerous weapon as committed by "a person who knowingly possesses a dangerous weapon"); id. § 18-18105(1) (making it "unlawful for any person knowingly ... to possess . . . a controlled substance"); see also Wayne R. LAFAve \& AUSTiN W. ScotT, Criminal LaW § 3.2(e), at 200-01 (2d ed. 1986). Many codes refine the defimition of possession to include the act of receiving contraband, and the act of retaining it when possession could have been terninated. See, e.g., Model PENAI CodE 
requirement of "possession" is relatively easy to satisfy, as compared with the affirmative act of concealment required under obstruction law. The same can be said of the mens rea element of most contraband laws. Typically, this element is satisfied if the defendant has "knowledge" or even "reason to believe" that the thing im his possession is of a forbidden nature. ${ }^{133}$ As compared with the purposive intent required by obstruction law, the level of awareness necessary for a contraband violation is easy to establish. Accordimgly, there is hittle reason to expect that attorneys who knowingly take possession of contraband im connection with a defense representation would later escape conviction.

Outside of contraband cases, existimg criminal statutes will seldom support prosecution of a lawyer for violation of the Olwell rule. To date, this inpression has been borne out by the decided cases. One must discount cases like Morrell that discuss the potential application of the criminal law to a lawyer's conduct. ${ }^{134}$ When faced with an actual prosecution and the responsibility of giving a definitive interpretation to a crimmal statute, the courts have been more circumspect. ${ }^{135}$ Among reported cases, criminal prosecutions of lawyers for failure to dehiver physical evidence to the government are exceedingly rare, ${ }^{136}$ and convictions upheld on appeal nonexistent. ${ }^{137}$ One suspects that the bark of the Olwell rule is worse than its bite. This is not to say that the broad statements in Morrell, Olwell, and other cases can be ignored; they have not been overruled and have been widely (if not universally) endorsed by other courts. One

$\S 2.01(4)$ (1985) ("[P]ossession is an act, within the ineaning of this section, if the possessor knowingly procured or received the thing possessed or was aware of his control thereof for a sufficient pericd to have been able to terminate his possession.").

133. See MOdel Penal CODE $§ 223.6$ (1980) (defining offense of "receiving stolen property" to require knowledge that it has been stolen or a belief that it has probably been stolen).

134. Other courts have joined Morrell in stating that a defense lawyer's failure to coine forward with evidence subject to the Olwell duty might result in a criminal conviction for obstruction of justice or concealing evidence. See, e.g., Williams v. State, 368 S.E.2d 742, 747 (Ga. 1988); State v. Green, 493 So. 2d 1178, 1182 (La. 1986).

135. See, e.g., Commonwealth v. Stenhach, 514 A.2d 114 (Pa. Super. Ct. 1986) (holding that Pennsylvania's statutes regarding hindering of prosecution and tampering with evidence are unconstitutionally vague when applied to criminal defense lawyers); $c f$. Pcople v. Belge, 372 N.Y.S.2d 798 (Onondago County $\mathrm{Ct}$.) (dismissing obstruction of justice charges premised on violations of public health statutes), aff'd, 376 N.Y.S.2d 771 (App. Div. 1975), aff'd, 359 N.E.2d 377 (N.Y. 1976) .

136. The only two reported cases are Stenhach and Belge. Both cases resulted in convictions by the jury, but reversals on appeal. The lawyers in both cases were later cleared of disciplinary charges as well. See Office of Disciplinary Counsel v. Stenhach, Pa. Super. Ct. Disciplinary Bd., No. 479, Disc. Docket No. 2 (Super. Ct. Aug. 8, 1989); New York State Op. 479 (1978). For an account of one unreported case, see Lefstein, supra note 12, at 919, describing Commonwealth v. Schaffner, No. 81-CR-371 (Ky. Cir. Ct. 1982) (attorney aequitted of tampering with physical evidence charges after his failure to deliver a knife to the prosecution in a homicide case).

137. The Stenhach court noted that "we are not aware of any case in any state in which an attorney was convicted of a crime for conduct similar to that of appellants." $514 \mathrm{A.2d}$ at 124 . 
may doubt, however, that the rationale of Olwell and its progeny fully supports the principles they articulate, or, based on the historic record, that the will exists to enforce those principles against lawyers who fail to produce chent-incriminating evidence.

\section{Policies and Emotions of the Olwell Rule}

Apart from the substantive law bases of the Olwell rule, extralegal factors surely underlie rulings in individual Olwell cases. The driving forces in these decisions are policy concerns and strong emotional responses to the cases at hand. Although not always articulated by the courts, these are nonetheless worthy of consideration. Soine of them may be translatable imto legal doctrine, thus supplying a fornal basis for the Olwell rule that to date has been missing. On the other hand, a probing evaluation of the policies and emotions of the Olwell rule inay further suggest that the rule cannot be justified in its present form.

1. Anti-Hindrance Policies. To some extent, Olwell furthers the policy view that the government's access to probative evidence in a crininal case slould be maximized in the absence of a very good reason not to do so. It also furthers the corollary view that the power of defense lawyers to interfere with the government's search for evidence should be closely regulated. Where the intervention of defense counsel is thought to produce an obstacle to law enforcement that would not otherwise be present, this poticy is engaged. ${ }^{138}$

There are three principal ways in which a defense lawyer who takes possession of physical evidence might hinder the efforts of law enforcement. First and most significantly, nearly all of the Olwell cases speak of the danger that attorneys will become "depositories" for incriminating

138. It is easy to find reflections of such an anti-hindrance policy in the law. The obstruction statutes surveyed in the preceding section are unambiguous embodiments of this view. Beyond this, however, Olwell might be seen as advancing a second policy that all citizens, or defense lawyers in particular, should be required to come forward and assist the government in its investigation of crime by supplying all evidence that might relate to a criminal offense. This goes far beyond the anti-hindrance view to impose an affirmative duty upon counsel to come forward with evidence that the government might not otherwise request or discover. Such a policy of affirmative assistance is considerably more difficult to locate in our present laws. Criminal liability is generally not inposed for failures to act. As a consequence, citizens are not required to report crimes or assist in the apprehension of offenders. See MODEL PENAL CODE $\S 2.01(3)$ commentary at 222 (1985) (setting forth the "conventional position" that there is no criminal liability for omissions unless expressly provided by the law defining the offense, or a duty to perform the oinitted act is otherwise imposed by law); see also Glanville Williams, Criminal Law: The General Part 3-8 (2d ed. 1961). 
evidence. ${ }^{139}$ This concern stems from an assumption that evidence in an attorney's hands is significantly less aceessible to law enforcement agencies than it would be outside the attorney's possession. Therefore, mere possession by a lawyer is viewed as an obstacle to government access. ${ }^{140}$ Under present law, this assumption is often justified. For example, some jurisdictions hold that search warrants may not be executed upon a law office, or can issue only under limited circumstances. ${ }^{141}$ The special insulation of the law office derives from the fact that evidence "deposited" with a lawyer is stored alongside confidential material of many descriptions, usually from a number of chients, that cannot be perused by government agents. ${ }^{142}$ Figuratively speaking, it is impossible for investigators to locate a needle in a haystack if they are forbidden to go near the haystack. The "depository" problem thus focuses upon the potential misuse of the confidentiality extended to lawyers and their workspaces.

139. See, e.g., Clutchette v. Rushen, 770 F.2d 1469, 1473 n.1 (9th Cir. 1985) (finding no Sixth Amendment objection to Olwell rule because right to couusel does not embrace "the right to sequester critical evidence in the possession of one's attorney"); In re January 1976 Grand Jury (Genson), 534 F.2d 719, 727 (7th Cir. 1976) ("[R]ecognition that an attorney need not produce stolen monies in response to a subpoena would provide a mechanism by which a member of a learned profession could beconie the privileged repository of the fruits of a violent crime."); Morrell v. State, 575 P.2d 1200,1212 \& n.22 (Alaska 1978) (finding that, under state law, attorney did not breach his ethical obligation by revealing evidence about his client which the attorney knew was being sought in an mvestigation); Hitch v. Pima County Superior Court, 708 P.2d 72, 78 (Ariz. 1985) ("[W]e do not wish to create a situation in which counsel is inade a repository for physical evidence."); People v. Mereditl, 631 P.2d 46, 53 (Cal. 1981) (extending attomey-client privilege to cases where defense counsel removes evidence imight encourage defense counsel to race the police to recover evidence).

140. See Morrell, 575 P.2d at 1212.

141. Minnesota forbids search warrants executed on law offices. See O'Connor v. Johnson, 287 N.W.2d 400 (Minn. 1979). California regulates law office searches by statute. See CAI. PENAI CODE § 1524(c)-(f) (West 1982). Other states, such as Pennsylvania, consider law office searches no different than other searclies and allow warrants to issue when routine Fourth Amendinent requirements are met. See In re Search Warrant B-21778 (Gartley), 521 A.2d 422, 428 (Pa. 1987). See generally Michael A. Mogill, Avoiding "The Big Chill": Protecting the Attorney-Client Relationship from the Effects of Zurcler, 21 CONN. L. REv. 293 (1989).

142. The courts have sanctioned parties who gained unauthorized access to privileged or confidential material relating to a lawyer's representation of a client. See Cutillo v. Cinelli, 485 U.S. 1037 (1988) (White, J., dissentimg from denial of certiorari) (arguing that there exists confiict among the circuits with respect to burdens and standards im this area); Cinelli v. City of Revere, 820 F.2d 474, 478, 480 (1st Cir. 1987) (finding possible Sixth Amendment violation where confidential defense strategy infornation is transmitted to the prosecution); United States v. Ofshe, 817 F.2d 1508, 1516 n.6 (11th Cir.) (suggesting that prosecutor's conduct in wiring private attorney during conversations between attorney and client may liave been disciplinary violation), cert. denied, 484 U.S. 963 (1987); see also In re Beiny, 522 N.Y.S.2d 511 (App. Div. 1987), appeal dismissed, 524 N.E.2d 879 (N.Y. 1988) (disqualifying law firm in private litigation for knowing misuse of state's discovery rules to obtain opposing party's confidential information); In re Beiny, 517 N.Y.S.2d 474 (App. Div. 1987). 
The second way in which an attorney who takes custody of physical evidence might hinder law enforcement is unrelated to her protected status or that of her office. Any movement of evidence, or any change of possession, can make discovery by the government less probable. The police, for example, may trace an object from person A to B, but be unable to reconstruct its final transfer to person C. An attorney who takes evidence from another person adds one link in the chain of possession, makes more work for the government, and introduces the possibility that the evidence will never be obtamed. ${ }^{143}$ A similar effect ensues when counsel takes evidence from a public place ratler than from a person. Again, the lawyer lias rendered the government's work more difficult merely by moving the evidence. In addition, once a lawyer or any private party takes possession of a thing, the government may liave to resort to formal procedures (sucli as a subpoena or a search warrant) to obtain it. The prospects are gone that the police might discover the evidence during their own mvestigation or liappen upon it madvertently, or that a bystander might find it and bring it to the police's attention.

Third, as recognized in Meredith, removal of plyysical evidence by a lawyer away from a specific location or person may render the evidence less meaningful to the government because its location in that place or its possession by that imdividual was itself a fact relevant to the investigation. ${ }^{144}$ Thus, even if the prosecution recovers the object from counsel, important contextual information may liave been lost. Like the lawyer, any private person can create this third kind of difficulty for the government. In some circumstances, lowever, a lawyer may be permitted to refuse to explain where sle got the evidence when a private person could not. ${ }^{145}$

All three anti-hindrance concerns are legitimate. The depository problem, because it derives from laws and rules created to safeguard lawyers' workplaces, seems to require a solution addressed to the special situation of lawyers. The second and third concerns, on the other hand, do not suggest a response focused narrowly upon defense attorneys. Instead, they expose the fact that the general population is given freedom to do or fail to do many things even though the known result impedes law

143. For example, in a case like Olwell, the police might learn that the defendant purchased a knife from a friend, thus establishing the knife's inovement from the friend to the defendant. If, lowever, the defendant subsequently transferred the knife to counsel, the police miglit not discover that this has occurred. Thus, even if a law office search were allowed in theory, the police would lack information needed to obtain a warrant.

144. See supra Part II(A)(3).

145. For example, an attorney who was led to the crime scene by the client or who was given evidence by the client might successfully claim that the circumstances of acquisition of evidence are protected under tlie attorney-client privilege. 
enforcement. Although it may be appropriate to reexamine these outcomes, the problems presented are larger and more fundamental than those entailed in the lawyer-chent relationship. For example, if we seek to impose on everyone a greater responsibility to help solve crimes, longestablished notions surrounding the ormssions doctrine must be overturned. 146 While there inay be good reasons for doing so, the emerging rule would not and should not be crafted to apply to lawyers alone.

2. Emotions. Another important factor at work in the Olwell cases is less rational than anti-hindrance concerns. In addition to mstrumental goals, Olwell reflects a powerful emotional aversion to the thought that private attorneys should have custody of graphic or "dramatic" evidence of violent crime. ${ }^{147}$ There is soinething grisly about the idea, and our emotional response increases with the level of violence of the crime and our sense of proximity of the evidence to the violent act. It is no accident that so many of the Olwell cases involve objects that carry high "dramatic" value, quite apart froin their potential evidentiary worth, and that virtually all Olwell cases involve crimes of violence. Olwell itself is a good illustration. One cannot think of the actual murder weapon without revulsion, without imagining blood on the knife and the brutality of the crime. It is as though the weapon itself had taken on an evil cliaracter through its use im a heinous crime. Most people would feel lorror if presented with such an object in everyday life. Because of this, we have difficulty countenancing the conduct of a lawyer who coldly handles and collects such items. ${ }^{148}$

In thinking about the "dramatic" character of evidence that has been made subject to the Olwell rule, one cannot lielp but coinpare it to less "dramatic" physical evidence that seldom, if ever, is thouglit to fall within Olwell's reach. The principal category of such "nondranatic" evidence is documentary evidence of so-called white-collar crime. ${ }^{149}$ No

146. See supra note 138.

147. For lack of a better label, I will refer to such evidence as "dramatic" evidence, retaining the quotation marks to indicate that I regard the label, together with the category it attempts to denote, as suspect.

148. This argument can be restated in terms of a concern for public perceptions regarding defense lawyers and the workings of the criminal justice system. See Commonwealth v. Stenhach, 514 A.2d 114, $118(\mathrm{~Pa}$. Super. Ct. 1986) (government asserted that "[t]o exempt attorneys from the statutory proscriptions against tampering with evidence will not enhance public perceptions of lawyers as a positive force in the administration of justice, but will cast them in the public mind more as aceessories to crime").

149. "White-collar crime" is a loose term without adequate definition. For purposes of this article, however, I adopt Edwin Sutherland's definition that white-collar crime is crime committed by "persons in the upper socioeconomic class." EDWIN H. SUTHERLAND, White Collar CRIME: THE UNCUT VERSION 7 (1983). 
Olwell case has ever held, for example, that papers implicating a client in a tax offense must be produced by defense counsel on her own motion if she takes possession. Nor has an Olwell case held that counsel for a savings and loan institution must come forward with the "smoking-gun" memorandum setting out the chient's criminal plan to circumvent banking regulations. Perhaps Olwell decisions of this kind do not exist because such paperwork evidence, although highly incriminating to the chent, is not sufficiently "dramatic" in the sense I have explored above. ${ }^{150}$ It inay also be, however, that the Olwell rule does not extend to such circumstances because of the class status of suspects in whitecollar cases. The typical middle- or upper-class white-collar offender is held less subject to the risk that his defense lawyer will feel compelled to turn in evidence against him than his counterpart, the less affluent "street-crime"151 offender.

To be fair, the strong reaction we have to "drainatic" evidence of violent crime cannot be attributed wholly to emotion, superstition or classisin. There is a colorable but flawed argument that such evidence, because of its suspected close cormection to a physical crime, inay have extraordinary, even conclusive, probative value. For example, a weapon that belongs to the defendant, that bears only the defendant's fingerprints, and that has traces of the victimi's blood and hair, tells by itself the whole story of the crime. It may be that the Olwell courts have, without inuch thought, implicitly concluded that certain kinds of evidence are so likely to be unusually important that it would be intolerable to allow defense lawyers to keep them and not turn thein over to the authorities. Such an impulse, however, could hardly justify the courts' failure to extend Olwell to white-collar cases. An incriminating docuinent may be just as critical to the government's case in one prosecution as physical evidence in another.

150. Morrell is a mixed case under this analysis in that it involved documentary evidence of a violent street crime. Plainly, all documents would not fall outside the category of "dramatic" evidence. Some, hike the kidnap plan in Morrell, can elicit as strong an emotional response as would a weapon used in a crime.

151. I have borrowed this broad term from KENNETH MANN, DEFENDING WhITE-CollaR Crime: A Portrait of ATtorneys at Work $4 \mathrm{n}$.* (1985), as a rough means for distinguishing between the relatively sophistieated crimes committed by white-collar offenders, and those other offenses that make up the bulk of the criminal docket. 


\section{Must the Olwell Rule Be Extended to Incriminating Documents in White-Collar Cases?}

There is no good reason to restrict Olwell's apphication to physical evidence of violent street crime while failing to extend it to record evidence in white-collar cases. If a client's smoking gun must be produced by counsel, it is difficult to see why a smoking-gun document must not also be produced. The overriding policy of Olwell, to make important incriminating evidence available to the government, applies with equal force to the most grisly physical evidence of violent crime and to the driest, most technical, but equally incriminating document that demonstrates the commission of a white-collar crime. Therefore, if we accept the propriety of the Olwell rule in the first place, it must apply even when client-incriminating evidence takes the form of business records, memoranda, correspondence, personal financial records, and so on. ${ }^{152}$

As noted above, there is a dearth of caselaw that apphies Olwell to documentary evidence of white-collar crime. ${ }^{153}$ In fact, the decided cases in which such an issue could have been presented are striking: Fisher $v$. United States ${ }^{154}$ is representative of a legion of white-collar cases notable for the absence of any concern for the Olwell rule. Fisher arose after defense lawyers for a number of taxpayers took possession of tax workpapers that the lawyers and taxpayers asserted were potentially evidence of crime. ${ }^{155}$ Throughout the Fisher hitigation, no one ever intimated that the defense lawyers might be obligated to coine forward on their own motion with the damaging evidence instead of litigating its producibility. When matched agamst the precepts of Olwell, cases like Fisher are mystifying in their failure to deal with counsel's duty to come forward with inaterial evidence.

Neitler the law underlying the Olwell rule nor its policy justifications can explam the courts' failure to recognize Olwell in white-collar cases. The obstruction laws that are most often given as the legal basis for the Olwell duty do not distimginish between documentary and other evidence, nor do they apply only when the investigation concerns a crime

152. Morrell has been cited by the Pennsylvania Supreme Court in support of dictum that counsel has an Olwell-based duty to make voluntary production to the authorities of her client's incriminating business records. See In re Search Warrant B-21778 (Gartley), 521 A.2d 422, 429 (Pa. 1987).

153. See supra text aecompanying notes 149-50.

154. 425 U.S. 391 (1976). Fisher is discussed infra in Part III.

155. The admission occurred through the taxpayers' assertion of their Fifth Amendment privilege with respect to the papers. The actual incriminatory character of the records was not established in Fisher, but it is not unusual for the Olwell rule to be applied in the absence of such a determination. In fact, this is the typical scenario. See infra Part II(E)(1). 
of violence or other street crime. ${ }^{156}$ It is true that contraband statutes, sometimes given as the foundation for the Olwell rule, have limited relevance to the paper evidence generated during white-collar offenses. This is not umiversally true, however, as even documents can be stolen property and thus contraband. Moreover, contraband laws play a small role in the reported Olwell cases. The kidnap plan in Morrell, for example, or the knife in Olwell itself, was not contraband; knowing possession by counsel was not a crime in itself. The courts' failure to apply Olwell in white-collar cases can hardly be explained with reference to differential application of the contraband laws in white-collar and street-crime settimgs.

From a policy perspective, it is equally difficult to understand Olwell's absence from white-collar cases. There is no reason to be less concerned about lawyers acting as depositories for incriminating records than for other sorts of evidence. An important document im the law office is shielded froin the government by its placement among privileged material just as a gun would be. If anytlimg, it is much easier for the pohice to search a law office for a gun than for a piece of paper. A search for damaging records normally requires the officer or agent to look at all of the documents in the law office, and many of these will be protected by some form of privilege. ${ }^{157}$ A search for a gun, however, requires no wide-ranging perusal of files and entails hittle risk of inadvertent intrusion on confidential materials.

In another way it is easier to justify application of the Olwell rule to a document than to other physical evidence. Documents can easily be copied, and the copies retained for contimuing study by the defense lawyer following production to the government. In this respect, although turning over the original records may incriminate the client (as may all production of evidence under Olwell), production will have little impact on counsel's ability to prepare a defense. Indeed, even the "reasonable period" of retention of evidence allowed in Olwell might be shortened for documents once they have been identified as potentially incriminating and subject to production under the Olwell rule. Counsel would have no need to make as full a study of the records before turning them over as,

156. Admittedly, I have asserted that obstruction laws do not easily or often fit the situation where a lawyer takes evidence relating to a defense representation. See supra Part II(B)(1). If such laws provide a satisfactory basis for the Olwell rule in a street crime ease, however, they serve equally well in a white-collar case.

157. See Zurcher v. Stanford Daily, 436 U.S. 547, 573 n.7 (1978) (Stewart, J., dissenting) ("[I]n order to find a particular document, no matter how specifically it is identified in the warrant, the police will have to search every place where it might be-including, presumably, every file in the office-and to examine each document they find to see it is the correct one."). 
for example, she may need for ballistics or fingerprint tests on a weapon. All that is required is the necessary interval to make copies.

If there is any basis remaming for the current restriction of the Olwell rule to street crime, and its nonapplication in white-collar cases, it must be found in the emotional or class-discriminatory underpinnings of the rule; it cannot be supported in law or pohicy. However, we could hardly fashion a legal rule to determine the application of Olwell based upon the level of emotional aversion induced by a given item of physical evidence. As Morrell illustrates, a blanket distinction between documents and other physical evidence fails to capture this emotional component, because highly charged papers would be placed outside the reach of Olwell, along with the most unexciting of financial records. A case-bycase standard, designed to separate items of "dramatic" or "repulsive" evidence from other incriminating material, is unworkable and incoherent.

In addition, it is simply not true that "dramatic" physical evidence of violent crime is more hikely to be probative than "boring" physical evidence of white-collar crime. The evidentiary value of any item, whatever its character, depends on tlie particular case, not on the item's inherent nature. We could perhaps fashion a rule requiring defense attorneys to turn in all evidence against their clients that is "especially" or "enorinously" mcriminating. If we did so, however, and im the unlikely event the rule were followed assiduously, prosecutors would receive docuinents from white-collar defense counsel in equal proportion to the more graphic physical evidence received from the street-crime lawyers.

Finally, the failure to bring Olwell into white-collar cases is troubling in that it suggests rather starkly that tle law has grown to afford greater respect for the passivity rights of affluent white-collar suspects than for the identical riglits of street-crime suspects. This might be explamed by the fact that courts and prosecutors, consciously or unconsciously, tend to identify more readily witli white-collar suspects and are therefore sensitive to tlieir procedural rights-including tlieir need to obtain counsel who can prepare a defense witl hittle concern that damaging evidence must be turned over to the government.158 When the same opportunities for sensitivity appear in the street-crime setting, however, the suspect's passivity rights and need for effective counsel have not been weighed as heavily.

158. See Stanton Wheeler et al., Sitting in Judgment: The Sentencing of WhiteCollar Criminals 160-63 (1988) (noting problein of special judicial sensitivity and einpathy for the plight of white-collar defendants). 
Having observed this irrational and discriminatory effect, we should not tolerate it. If we are serious about the Olwell rule and are determined to retain it, we must be willing to apply it in all criminal investigations and prosecutions, to embrace white-collar defendants, their lawyers, and their file cabimets of incriminating documents. On the other hand, we may that Olwell is unsupportable if so extended, and has been unsupportable all along.

\section{E. The Reach of the Olwell Rule}

No discussion of the Olwell rule would be complete without reference to the relative infrequency of the rule's invocation, and some thought given to the reasons for this. In the more than twenty-five years since Olwell was decided, there have been strikingly few Olwell-rule cases. ${ }^{159}$ Perhaps this is because defense lawyers rarely turn over physical evidence to the authorities when they are supposed to do so, and because it is difficult to detect violations. If so, then Olwell hitigation would arise only im the unusual circumstances where, as in Morrell, a defense lawyer had a particularly sensitive conscience and made voluntary production, or where the lawyer's failure to come forward with evidence is somehow discovered later.

Aside froin these factors, two interual characteristics of the Olwell rule dictate that it will have limited application. First, the Olwell rule is hobbled by the problem, which has never been addressed adequately by the courts, of how certain a lawyer inust be that evidence in her hands is in fact imcriminating to her client before the Olwell duty arises. In the vast majority of situations the attorney will have some uncertainty on this score, and must be allowed to give the benefit of the doubt to her client. Second, the Olwell rule as presently constituted will never be invoked to disapprove the conduct of large numbers of lawyers, because of its inherent indeterminacy and because lawyers are asked to apply its terms entirely on their own, without the opportumity to test the extent of their disclosure obligations in an adversary forum.

1. Standard of Knowledge. How certain must a defense attorney be that evidence in her possession is really incrimmating to her chent before Olwell's duty of production arises? The answer to this question is a critical variable in defining the scope of the Olwell rule. If certainty or actual knowledge is required, the duty of production will seldom arise. On the other hand, if a less stringent standard is applied, such as a "reasonable belief" that evidence is incriminating, a larger number of cases

159. See supra note 49 (listing reported decisions). 
will fall within the rule. For the reasons given below, I suggest that counsel must have actual knowledge concerning the guilt of her chent and the incriminating character of the evidence before the Olwell rule is activated.

The cases have rarely addressed this important issue, and have never done so with close attention. ${ }^{160}$ Rather, courts typically write their opinions with the apparent assumption that the chent is guilty and that the physical evidence in the lawyer's possession will help prove it. Such assumptions can be unwarranted. In Olwell, for instance, it was ultimately discovered that the knife in the attorney's possession was not the weapon used in the homicide. ${ }^{161}$ Focusing on this fact, which the Washington Supreme Court knew when it rendered its decision, casts Olwell in a new hight. What standard of knowledge on the part of the attoruey could the court have been thinking of to trigger the self-activating duty of production? Perhaps the attorney's duty was ineant to extend to all physical evidence that might incriminate the chent, even when there is a substantial possibility that the evidence is not inculpatory. The court failed to say.

In Morrell too, the issue is probleinatic and went unaddressed by the court. Before Cline engineered production of the kidnap plan to the pohice, Morrell had given him an explanation for the plan that inay have been far-fetched but, if accepted, inade the document wholly innocent. Neither Cline nor the court beheved the story. However, Morrell maintained his innocence through trial and sentencing, insisting that his relationship with the victim had been consensual. Again, this inay have seemed highly unlikely to defense counsel but, if true, it rendered the kidnap plan an innocuous paper, and not evidence of a crime. ${ }^{162}$ As in Olwell, however, the Morrell court failed to speak to the issue of the degree of certainty a lawyer must have as to the mcriminating character of evidence potentially subject to the Olwell duty. ${ }^{163}$

160. Along with Olwell and Morrell, other courts have failed to articulate any standard regarding the lawyer's degree of suspicion or knowledge that the evidence in her possession is in fact evidence of crime. See, e.g., Williams v. State, 368 S.E.2d 742 (Ga. 1988); Hitch v. Pima County Superior Court, 708 P.2d 72 (Ariz. 1985); Anderson v. State, 297 So. $2 d 871$ (Fla. Ct. App. 1974). Without explanation, the court in State v. Green, 493 So. $2 \mathrm{~d} 1178$ (La. 1986), laid out the following standard: "[The defense attorney] was under an obligation to turn over evidence which he reasonably believed to be inaterial to the crime charged or to the investigation of a crime." Id. at 1182 (emphasis added). None of the authorities cited in Green articulates a "reasonable belief" standard, or discusses what standard is appropriate in triggering the Olwell duty.

161. See Olwell, 394 P.2d at 683 n.1.

162. I do not make a brief for Morrell's innocence. Rather, it seems to me fundamental that defense counsel, unique among all others, must give the benefit of every doubt to the client.

163. The court at one point said an attorney inust turn over to the prosecution "real evidence that the attorney obtains froin his chent," without placing any qualification on the type of real 
The issue at the heart of this problem is whether, and under what circumstances, we will require defense counsel to make independent factual determinations adverse to their clients, and then step out of their role as advocates to provide active assistance to the prosecution. In my view, our rules should generally instruct defense lawyers that they may not do sucli things. ${ }^{164}$ If we require counsel to do so at all, the requirement must be limited to cases in whicli counsel has actual knowledge that evidence in her possession is in fact evidence of a crime.

Precedent for an actual knowledge requirement can be found in the caselaw and conduct rules that have grown up around the problem of attorneys' duty to report client perjury to the court. In Nix $v$. Whiteside, ${ }^{165}$ the Supreme Court held that a defense lawyer did not act improperly in advising his client that, if the client perjured himself on the stand, lie would inform the trial court of the perjury, withdraw as counsel, and perhaps even testify as a government witness in later proceedings. ${ }^{166}$ The Court's approval was based on the finding below that the client's "intended testimony would have been perjurious"167 and that the lawyer knew of this intention because the client announced it to him. ${ }^{168}$ Following Nix, the ABA issued a formal opinion stating that a lawyer's obligation to disclose arises only "where the lawyer knows that the client lias committed perjury, ordinarily based on admissions the client has made to the lawyer."169

evidence, its bearing on the case, or its incriminating character. See Morrell, 575 P.2d at 1210. A bit later, the court said that the attorney's ethical duty extended to "relevant evidcnce in a criminal case." Id. at 1211 (emphasis added). A standard of relevancy, if the court intended it as a serious proposal, would be enormously broad.

164. Justice Blackmun put it well in Nix v. Whiteside, 475 U.S. 157 (1986): "Except in the rarest of cases, attorneys who adopt 'the role of the judge or jury to determine the facts' . . pose a danger of depriving their clients of the zealous and loyal advocacy required by the Sixth Amendment." Id. at 189 (concurring opinion of Blackmun, Brennan, Marshall, and Stevens, JJ.) (quoting Uinited States ex rel. Wilcox v. Johnson, 555 F.2d 115, 122 (3d Cir. 1977)).

165. 475 U.S. 157 (1986).

166. See id. at 176. The issue in $N i x$ was whether the defense lawyer had provided ineffective assistance of counsel in taking these steps. The Court concluded that the lawyer's conduct comported with the standard of professional rcasonableness set down in Strickland v. Washington, 466 U.S. 668 (1984), and with the rules of professional conduct found in the Model Code of Professional Responsibility and Model Rules of Professional Conduct. See Nix, 475 U.S. at 169-70.

167. Nix, 475 U.S. at 162-63.

168. Id. at 170 . Justice Stevens, in a concurring opinion, remarked that the clarity of factual knowledge as perceived by an appellate court, based upon findings below, will not often exist from the perspective of a lawyer in the middle of a case who does not believe her chent's proposed testimony. See id. at 190 (Stevens, J., concurring).

169. ABA Comm. on Ethics and Professional Responsibility, Formal Op. 353, at 7 (1987) (footnote omitted). The knowledge requirement also appears in MODEL RULES OF PROFESSIONAL CONDUCT Rule 1.2(d) (1989) ("A lawyer shall not counsel a client to engage, or assist a client, in conduct that the lawyer knows is criminal or fraudulent."); id. Rule 3.3(a)(2) ("A lawyer shall not knowingly ... fail to disclose a material fact to a tribunal when disclosure is necessary to avoid assisting a 
Such an actual knowledge standard is appropriate in the Olwell setting, as well. Perhaps a demanding standard of this kind is being apphed by defense lawyers in the absence of guidance from the courts. If so, this helps explain the low incidence of Olwell-rule cases, and suggests that their numbers will remain small.

2. Retrospective Application. Special issues are presented when a defense lawyer is asked to make self-initiated decisions regarding the production of evidence. First, it is the defense lawyer, not the prosecutor, who must determine that an issue has arisen. Instead of responding to a specific legal command that designates what evidence and information is sought by the government, defense counsel bears responsibility both for formulating the command as well as responding to it. This puts a considerable weight on the defense lawyer's shoulders.

Further, when presented with a specific legal command such as a subpoena, the defense attorney has the opportuuity to hitigate the issue of comphance. Final responsibility for deciding whether the requested material must be produced lies with the courts, not with counsel herself. The availability of an adversary procedure operates as a protection for the lawyer, allowing her to assert all reasonable argnments for withholding production, but instructing her when these argnments are found unacceptable. She is thus insulated from disciplinary or other consequences that could follow a wrong guess in the direction of either producing or withholding evidence.

In contrast, a lawyer wrestling with the Olwell rule has no protective resort to the adversary process. Along with responsibility for identifying the issue in the first place, the decisionmaking authority falls upon counsel alone. She must set her course without the benefit of judicial imprimatur and is vulnerable to sanctions if later found to have improperly betrayed her chent or to have improperly withheld evidence. In recognition of these problems of indeterminacy, one might expect that the courts and disciplinary boards would afford wide latitude to the lawyer's decision precisely because she was forced to operate in an environment fraught with uncertainty. Thus, it is unsurprising that the Olwell cases

criminal or fraudulent act by the client."); MODEL CODE OF PROFEsSIONAL ResPonsibiLITY DR 7102(A)(4) (1982) ("[A] lawyer shall not . . . [k]nowingly use perjured testimony or false evidence."); id. DR 7-102(A)(7) ("[A] lawyer shall not ... [c]ounsel or assist his chient in conduct that the lawyer knows to be illegal or fraudulent."). See also Michael L. Bender, Nix v. Whiteside: The Perjurious Client Dilemma-What Should Defense Counsel Do?, 15 Colo. LAw. 21, 23 (1986) (arguing that "clear-cut" situations of client perjury are rare and exist only "when the chent tells the lawyer directly that he intends to offer false testimony"); Harry I. Subin, The Criminal Lawyer's "Different Mission": Reflections on the "Right" to Present a False Case, 1 GEo. J. LEGAL ETHICs 125, 136-43 (1987) (refuting the theory that "an attorney cannot know the truth until a court decides it"). 
rarely hold that counsel acted improperly in choosing to produce evidence, and that few cases sanction lawyers for an improper failure to do so.

\section{F. Transition}

The Olwell rule, as articulated in court opimions, requires defense counsel to coine forward with chent-incriminating evidence, and soinetimes to provide information and testimony concerning the evidence as well. In a number of ways, I have tried to suggest that the Olwell rule cannot possibly inean what it says, and that we do not or should not take the rule seriously as stated. For one thing, the rule's substantive law basis is considerably narrower than the enunciations usually inade by the courts. Apparently Olwell ouly operates when a lawyer's failure to produce evidence would be a criminal offense. Based on the low rate of reported convictions upheld on appeal, courts are rarely willing to find the criminal law prerequisites for Olwell firmly in place.

Alternatively, even if we find the concept of Olwell legally supportable, we cannot take it seriously because it has been given an unduly lim. ited scope by the courts, in their failure to extend it to white-collar crime settings. This is a further demonstration that Olwell stands upon an infirm foundation. The failure of Olwell to reach white-collar suspects and their counsel may stem from an appropriate regard, im that context, for the constitutional and other procedural protections that should be afforded all criminal suspects. ${ }^{170}$ However, there is one credible competing perspective: If we do not see fit to cut Olwell back on constitutional and policy bases, then we must greatly expand it so that it reaches sinokinggun documents on the same terms as smoking guns. Our willinguess to do so, which I doubt we have, is a test of our belief that Olwell states a defensible principle.

Part III of this Article will examine a series of problems that bear close relation to Olwell - those arising when a defense attorney is placed under subpoena or similar legal command to supply client-incriminating evidence to the governinent. One notable feature of the legal command cases should be highlighted in advance. The Olwell cases, it will be remembered, treat the chient's Fifth Amendment passivity rights as irrelevant when considering defense counsel's obligations to come forward with evidence. This is not universally true of the legal command cases. At least some of the time, the courts, including the Supreme Court, have given force to the chent's passivity rights when a defense lawyer is ordered to produce evidence. On occasion, production from an attorney

170. For further development of this position, see infra Parts III and IV. 
Inay be barred because the same production from the chent would intrude upon the client's self-incrimination privilege.

Part III will advance two principle conclusions. First, the soinetimes availability of Fifth Amendment analysis in legal command cases gives further reason to question the viability of the Olwell rule. In Part III(B), I will suggest that a great portion of Olwell has been invalidated sub silentio by legal command decisions now in force. Second, however, there are growing numbers of legal command cases in which the courts have not expressed regard for the passivity rights of the chent and, simpatico with Olwell, have ordered production of evidence from lawyers that could not be compelled from their clients. These decisions are surveyed in Part III(C). My conclusion here is that, although the legal coinmand cases represent an improvement upon Olwell in their occasional sensitivity to the client's passivity rights, they do not go far enough. Part IV therefore proposes that all of the problems studied in the Article, in the Olwell and legal command realms, sliould be rethouglit, and addressed through the creation of a projected Fifth Amendment privilege that inay be asserted by defense counsel on the chent's behalf.

\section{COUNSEL'S OBLIGATION TO COME FORWARD WITH INCRIMINATINg Evidence When Placed UNDER SPECIFIC LEGAL COMMAND}

We turn to problems presented when a criminal defense lawyer is placed under specific legal command to coine forward with evidence acquired in tle course of the representation of a client that might incriminate the client in past criminal conduct. Such legal commands can take a variety of forins. The most common is the subpoena, which can be issued in conjunction with a trial, ${ }^{171}$ grand jury proceedimgs, ${ }^{172}$ or other investigative proceedings. ${ }^{173}$ Agencies (such as the Internal Revenue Service) can issue administrative summonses that have legal force equivalent to a subpoena. ${ }^{174}$ And, of course, courts may issue specific orders directing individuals, including attorneys, to colne forward with

171. See, e.g., FED. R. CR1M. P. 17(c).

172. See, e.g., Branzburg v. Hayes, 408 U.S. 665, 688 (1972); United States v. Davis, 702 F.2d 418, 421 (2d Cir. 1983).

173. See State v. Olwell, 394 P.2d 681, 682 (Wash. 1964) (issuing subpoena ni conjunction with coroner's inquest).

174. See, e.g., 26 U.S.C. $\S \S 7602(b), 7604$ (a) (1988) (outlining IRS sunınıons power). 
evidence or information in pending hitigation. ${ }^{175}$ For purposes of the discussion that follows, I will treat all such specific legal coininands as essentially sinnilar. When such commands are directed to a defense lawyer, they identify specific evidence or information that the lawyer must provide. The commands carry the prospect of legal enforcement, usually through the contempt sanction, if the lawyer fails to comply. ${ }^{176}$

There is a commonly held perception that the number of legal coinmands addressed to defense counsel seeking client-incriminating evidence is on the upswing. ${ }^{177}$ In federal criminal proceedings there has been an explosion of hitigation concerning subpoenas to attorneys. State prosecutors have also been active in exploring the enforceability of attorney subpoenas, and have been meeting with success in the courts. Additionally, Congress and the IRS have imposed across-the-board requirements upon lawyers to disclose potentially client-incriminating financial information on a regular basis. ${ }^{178}$

Given these and other developments, ${ }^{179}$ there is growing concern that new governmental mvestigative and enforcement techniques are endangering the adversarial process in criminal cases, and will drive a wedge between defense lawyers and their clients. ${ }^{180}$ Part III examines the courts' uneven record in responding to legal command problems. Part III(A) studies the leading and emgmatic case of Fisher v. United

175. The power to issue such orders is varied.: Some are made pursuant to the discovery rules in a criminal or civil proceeding, and some pursuant to the court's general subpoena power. See FED. R. CRIM. P. 17(b). In criminal cases, the federal courts are thought to have inherent power to require both the prosecution and defense to produce previously recorded statements of trial witnesses. See United States v. Nobles, 422 U.S. 225, 231 (1975) (acknowledging "federal judiciary's inherent power to require the prosecution to produce the previously recorded statements of its witnesses"); Jencks v. United States, 353 U.S. 657, 668 (1957) (holding that an accused is entitled to inspect FBI reports of agents who testified at trial).

176. The Supreme Court has recently reaffirmed the grand jury's broad powers to issue subpoenas, and the government's ability to enforce them with a mimimal showing of the subpoena's relevancy to an ongoing investigation. See Umited States v. R. Enters., Inc., 111 S. Ct. 722, 728 (1991).

177. See supra note 5 ; infra note 301 .

178. See infra text aecompanying notes 304-07.

179. Another area of controversy is the forfeiture of defense attorneys' fees in connection with prosecution of their chents for drug and RICO offenses. See Caplin \& Drysdale v. United States, 491 U.S. 617 (1989); United States v. Monsanto, 491 U.S. 600 (1989). See generally Kathleen F. Brickey, Forfeiture of Attorneys' Fees: The Impact of RICO and CCE Forfeitures on the Right to Counsel, 72 VA. L. REV. 493 (1986); Steve Dettelbrah, Recent Development, Forfeiting the Right to Counsel, 25 HARV. C.R.-C.L. L. REV. 201 (1990) (arguing that the Supreme Court's decision to deprive a defendant of the use of "ill-gotten" assets to pay attorney's fees infringes on defendants' Sixth Amendment rights creating shortage of defense attorneys willing to aceept CCE and RICO cases).

180. See United States v. Klubock, 832 F.2d 649, 653 (1st Cir. 1987); Stern \& Hoffman, supra note 5 , at 1789 . 
States, ${ }^{181}$ which allows defense counsel in soine circuinstances to assert the client's Fifth Amendment privilege. Part III(B) pauses to consider the implications of Fisher upon the Olwell line of cases, and suggests that the two precedents cannot coexist. Part III(C) then reviews the expanding catalogue of legal command cases thought to fall outside Fisher's coverage, and which continue to be analyzed by the courts as though the chient's self-incrimination privilege were an irrelevancy.

\section{A. The Fifth Amendment Under Fisher v. United States}

Fisher v. United States ${ }^{182}$ is a watershed case that contains two distinct and important holdinigs relevant to this Article. ${ }^{183}$ First, Fisher addressed the question of what privileges a defense lawyer inay assert when served with a specific legal command to produce documents that niay nicriminate her client. The Court held that, when such records were received from the chent to obtain legal advice, the federal attorney-client privilege inandates that counsel inay not be coinpelled to produce the records if the chent would have enjoyed Fifth Amendment protection against the same compulsion. ${ }^{184}$ Thus, the legal command addressed to counsel can be niet with a claim of the attorney-chent privilege that allows assertion by the lawyer of the client's passivity riglits. I call this a "sinulated" Fifth Amendment privilege because it is an indirect assertion of the chent's self-incrimination rights. ${ }^{185}$

In a second holding, Fisher addressed the dimensions of the underlying passivity rights held by the clients when the governnient gives the clients theinselves a specific legal command to produce evidence. Here the Court enibarked upon a major rewriting of the Fifth Amendment privilege held by all suspects with respect to tlie compelled production of documents and, perhaps, other physical evidence. Fisher announced a new "act of production" approach for such circumstances ${ }^{186}$-an abstract and coniplex construct that is still ouly partially understood. Under the act of production doctrine, Fifth Amendment protection does

181. 425 U.S. 391 (1976).

182. Id.

183. For discussions of Fisher's impact upon Fifth Amendment jurisprudence, see Samuel A. Alito, Jr., Documents and the Privilege Against Self-Incrimination, 48 U. PrTT. L. Rev. 27 (1986); Robert S. Gerstein, The Demise of Boyd: Self-Incrimination and Private Papers in the Burger Court, 27 UCLA L. REv. 343 (1979); Robert Heidt, The Fifth Amendment Privilege and DocumentsCutting Fisher's Tangled Line, 49 Mo. L. REV. 439 (1984); Robert P. Mosteller, Simplifying Subpoena Law: Taking the Fifth Amendment Seriously, 73 VA. L. REV. 1 (1987).

184. See Fisher, 425 U.S. at 405.

185. Under Fisher, the simulated privilege is actually a subpart of the attorney-client privilege. See infra notes 198-203 and accompanying text.

186. See Fisher, 425 U.S. at $409-14$. 
not turn in any respect upon the nature or contents of the evidence sought by the government. Instead, the determinative issue is whether the suspect's conduct in making the evidence available to the authorities, rather than the evidence itself, entails an incriminating, testimonial communication.

1. The "Simulated" Privilege. Fisher involved two consohdated cases that arose out of IRS investigations of individual taxpayers suspected of civil and criminal violations of federal tax laws. In building its cases against the taxpayers, the IRS served summonses upon defense counsel demanding the production of accountant work papers and correspondence that had been given to the lawyers by their clients. ${ }^{187}$ The taxpayers and their counsel argued that the lawyers could not be compelled to produce the records because such production would contravene the taxpayers' passivity rights under the Fifth Amendinent. ${ }^{188}$ Early in its opinion, however, the Fisher majority flatly rejected any claim that a lawyer served personally with an order to produce documents should be permitted to resist comphance through a direct assertion of the client's self-incrimination privilege. ${ }^{189}$ Rather, the Court turned to the general rule, enunciated in Couch v. United States, 190 that the Fifth Amendment provides ouly a "personal privilege" that belongs to each individual and cannot be raised by third parties. ${ }^{191}$ Because the taxpayers themselves had not been compelled to do anything, the Court found that their selfincrimination rights were not iniphicated. The Court cited the view it had taken im earhier cases that an agent would not be permitted to claim the privilege on behalf of a principal and it extended this view to the attorney-chent relationship. ${ }^{192}$ No third party, the Court said, not even a

187. Id. at 393-94. In both cases, the taxpayers had retrieved from their accountants certain records relating to the preparation of their tax returns, including work papers, reports, correspondence, and copies of returns, and had transferred the records to their lawyers. Id. at 394.

188. Fisher, 425 U.S. at 395. See Brief for Petitioners at 23-27, Fisher (No. 74-18).

189. Fisher, 425 U.S. at 396-401. But see id. at $402 \mathrm{n} .8$ (noting the possible application of attorney-chent privilege as a bar to production).

190. 409 U.S. 322 (1973).

191. Fisher, 425 U.S. at 398. The Fisher Court also said that "the taxpayers retained any privilege they ever had not to be compelled to testify against themselves and not to be compelled themselves to produce private papers in their possession." Id.; see also id. at 397 (citing cases).

192. The two earlier agency cases were Couch v. Umited States, 409 U.S. 322 (denying accountant standing to assert client's Fifth Amendment privilege), and Hale v. Henkel, 201 U.S. 43 (1906) (foreclosing corporate employee from asserting his employer's Fifth Amendment privilege, if any). See also United States v. Nobles, 422 U.S. 225, 233-34 (1975) (Because the Fifth Amendment privilege is "intimate and personal," it "does not extend to the testimony or statements of third parties called as witnesses at trial."). None of the cases cited by the Court involved an assertion of a client's self-incrimination privilege by counsel. See Couch, 409 U.S. at 328, 329 (third party was suspect's 
lawyer representing a client, can assert the "personal" Fifth Amendment privilege on behalf of another. ${ }^{193}$

Following this initial ruling, lowever, the Court shifted its analysis to a ground not argued by the taxpayers: the attorney-client privilege. ${ }^{194}$ Under this new inquiry, the taxpayers' self-incrimination privilege became relevant after all. The Court reasoned that the policy behind the attorney-chent privilege was "to encourage chents to make full disclosure to their attorneys" to obtain informed legal advice. ${ }^{195}$ This policy would be defeated if chents learned that giving documents to counsel made them more vulnerable to legal process than they had been in the clients' hands. ${ }^{196}$ Once chents became aware of this, the Court said, they would be reluctant to allow their lawyers to take possession of potentially damaging records, even if their attorneys needed to study them to prepare a defense. ${ }^{197}$

To avoid this unwanted result, the Court ruled that transfers of documents by a chient to counsel to obtam legal advice gives rise to a "simulated" Fifth Amendment privilege ${ }^{198}$-an expression of the attorneychent privilege that allows the passivity rights of the chent to be asserted by counsel. ${ }^{199}$ In so doing, the Court endorsed the following passage from Dean Wiginore's evidence treatise: "It follows, then, that when the

accountant); Perlman v. United States, 247 U.S. 7, 15 (1918) (third party was another suspect); Johnson v. United States, 228 U.S. 457, 458 (1913) (third party was suspect's trustee in bankruptcy).

193. Fisher, 425 U.S. at 397-98. This continues to be the Court's view. See Moran v. Burbine, 475 U.S. 412, 433 n.4 (1986) (rejeeting "novel" agency theory that attorney niay assert chent's Fifth Amendnent rights because it is an "elemental and established proposition that the privilege against compulsory self-mcrimination is, by hypothesis, a personal one that can only be invoked by the individual whose testimony is being conpelled"). Prior to Fisher, the lower courts were split on the vicarious standing question. See In re January 1976 Grand Jury (Genson), 534 F.2d 719, 722-27 (7th Cir. 1976) (opinion of Pell, J.) (reporting disagreement ainong lower courts regarding vicarious standing and concluding that such standing is inappropriate in the instant case); In re Michaelman, 511 F.2d 882, 890 (9th Cir.) (holding that Fifth Amendment privilege is personal, without expressly overruling United States v. Judson, 322 F.2d 460 (9th Cir. 1963)), cert. denied, 421 U.S. 978 (1975); United States v. Kasnir, 499 F.2d 444, 454 (5th Cir. 1974) (recognizing vicarious standing), rev'd sub nom. Fisher v. Umited States, 425 U.S. 391 (1976); Umited States v. Goldfarb, 328 F.2d 289, 283 (6th Cir.) (denying vicarious standing), cert. denied, 377 U.S. 976 (1964); Bouschor v. United States, 316 F.2d 451, 458 (8th Cir. 1963) (denying vicarious standing); United States v. Judson, 322 F.2d 460 (9th Cir. 1963) (recognizing vicarious standing).

194. See Fisher, 425 U.S. at 402.

195. See id. at 403.

196. Id. at 404 .

197. Id. at 403. Presumably, conipetent counsel would have to warn every client that giving any docunient to the lawyer renders it vuhierable to process.

198. The Court did not use this term but I find it helpful to emphasize the nonconstitutional status of the objection permitted to counsel. See supra note 185 and acconipanying text.

199. Although the attorney-client privilege belongs to the chent and not the lawyer, it has long been held that counsel can assert it on the client's behalf. See, e.g., Republic Gear Co. v. BorgWarner Corp., 381 F.2d 551, 556 (2d Cir. 1967); Bouschor v. United States, 316 F.2d 451, 458 (8th 
client himself would be privileged from production of the document ... as exempt froin self-incrimination, the attorney having possession of the document is not bound to produce."200 To claim the privilege, counsel inust show that the prerequisites for both the attorney-client privilege and the client's passivity rights are in place. ${ }^{201}$

The initial question of the availability of the attorney-client privilege depends chiefly on the events leading to counsel's acquisition of evidence, such as whether the transfer was part of a coinmunication by the client to obtain legal advice.202 Once beyond this threshold, the analysis shifts away froin the lawyer and the fact that the lawyer has been coininanded to produce evidence. Instead, the relevant inquiry is whether the client, if he still had the evidence and had himself received a legal command to turn it over, could successfully resist production under the self-incrinination clause. ${ }^{203}$ Accordingly, the Fisher Court next focused its analysis on a hypothetical production by the taxpayers. ${ }^{204}$

2. The Client's "Act of Production" Privilege. The Fisher Court's treatinent of the imaginary production froin the taxpayers led to some startling new Fiftli Amendinent law. Fisher and its progeny have rebuilt the Fifth Amendinent concepts governing the compelled production of papers and objects, and created an "act of production" doctrine for such cases. $^{205}$

Cir. 1963). The Fisher Court noted that "it is universally accepted that the attorney-client privilege may be raised by the attorney." 425 U.S. at 402 n.8 (citations omitted).

200. Fisher, 425 U.S. at 404 (quoting 8 WigMORE, supra note $65, \S 2307$, at 592). The Court limited its agreement with Wigmore to circumstances "[w] here the transfer [of evidence] to the attorney is for the purpose of obtaining legal advice." Id. at 405 . The quoted excerpt is the same passage from Wigmore's treatise that had been advanced but rejected in State v. Olwell, 394 P.2d 681, 685 (Wash. 1964). See supra Part II(A)(1).

201. The simulated privilege is conceived by the Fisher Court as a part of the attorney-client privilege, and therefore is a common law privilege, not a constitutional one. In a later section, I will argue that the states are not bound to follow Fisher's simulated-privilege holding unless it has constitutional force not articulated by the Fisher Court. See infra Part III(B)(2).

202. In the case before it, the Fisher Court found that each taxpayer had "transferred possession of the documents in question from himself to his attorney in order to obtain legal assistance," thus engaging the attomey-client privilege. Fisher, 425 U.S. at 405 . The threshold showings necessary for assertion of the attorney-chent privilege are considered infra in Parts $\operatorname{III}(B)(1)$ and III(C)(1).

203. See Fisher, 425 U.S. at 405; accord United States v. Porter, 711 F.2d 1397, 1399 (7th Cir. 1983) (stating that Fisher mandates an inquiry where the scope of the attorney-client privilege is mcasured by the Fifth Amendment rights attaching to documents had they been in the client's possession).

204. See Fisher, 425 U.S. at 409-13.

205. The later cases include Baltimore City Dep't of Social Servs. v. Bouknight, 493 U.S. 549 (1990); Doe v. United States (Doe II), 487 U.S. 201 (1990); Braswell v. United States, 487 U.S. 99 (1988); United States v. Doe (Doe I), 465 U.S. 605 (1984). 
Before Fisher, surprisingly few Supreine Court cases had addressed the Fifth Amendinent law on the coinpelled surrender of incriminating private papers. The most recent major decision, Boyd v. United States, 206 was an artifact of the nineteenth century. Based on Boyd and dictum in later opinions, ${ }^{207}$ the availability of the privilege was thought to turn on the nature and contents of the records sought by the government. By its terms, Boyd prohibited the compelled production of "private books and papers." 208 The ideas transcribed in private writings were theinselves conceived as testinuonial communications worthy of constitutional protection, so that coinpelled production of an incriminating docunient was viewed as tantamount to extracting an oral confession. ${ }^{209}$ Accordingly, various types of private records were thought to enjoy Fifth Amendnient protection, ranging froin the thoughts recorded in personal diaries to the less intimate data contamed in personal financial records. ${ }^{210}$ Papers which by their nature and contents were deeined not to be private, such as corporate records, ${ }^{211}$ partnership records, ${ }^{212}$ or records required to be kept by law, ${ }^{213}$ were unprotected.

The ninovation of Fisher was a shift away froin the contents of the requested papers as a basis for privilege. Under the Court's new approach, the ideas contained in a docuinent imght well be classified as "testinioinal," Ineeting one of the three requireinents of Fifth Amendinent protection, ${ }^{214}$ but such communications would not be viewed as having been "coinpelled" as long as no governinent agent had coerced the author into writing his thoughts on the page. ${ }^{215}$ The operative tinie

206. 116 U.S. 616 (1886). Boyd involved a court order directing two partners to produce an incriminating invoice for goods that the partnership had allegedly attempted to import without paying the prescribed customs duty. The Coart held that compelled production of the invoice was unconstitutional nnder the Fifth Amendment. See id. at 633-35.

207. These decisions were canvassed in the Fisher majority opinion, 425 U.S. at $408-09$, and in Justice Brennan's separate opinion, id. at 419.

208. Boyd, 116 U.S. at 631-32.

209. See id. at 633 (stating that the Court was "unable to perceive" how requiring a suspect to produce his "private books and papers to be used in evidence against him is substantially different from compelling him to be a witness against himself").

210. See id. at 630; Bellis v. United States, 417 U.S. 85, 87-88 (1974); see also In re Grand Jury Proceedings (Johanson), 632 F.2d 1033, 1044 (3d Cir. 1980) (protecting private pocket diary).

211. See Wilson v. United States, 221 U.S. 361, 384-85 (1911).

212. See Bellis, 417 U.S. at 88 (overruling Boyd as applied to partnership records).

213. See Shapiro v. United States, 335 U.S. 1 (1948).

214. See supra Part I(A).

215. The Fisher Court explained: "[A]s far as this record demonstrates, the preparation of all of the papers sought in these cases was wholly voluntary, and they cannot be said to contain compelled testimonial evidence, either of the taxpayers or of anyone else." 425 U.S. at 409-10. See also Doe I, 465 U.S. at 610-11 (agreeing with Fisher that the Fifth Amendment only protects a person against compelled self-incrimination). 
frame for the compulsion requirement thus became the moment the evidence was created, not the later moment when its production is demanded by the government. ${ }^{216}$

In the Court's view, the act of production of evidence demanded by the government, even if accomplished without compelled verbal commumication on the part of the suspect, might still satisfy the tripartite passivity requirements of coinpulsion, testimiony, and incrimination. ${ }^{217}$ Here the presence of "compulsion" within the ineaning of the Fifth Amendment is no longer in doubt, because production of any evidence pursuant to legal command is undemably compelled conduct. Rather, the inquiry focuses upon whether the nonverbal act of production by itself may be regarded as conveying implicit testimiomal commumications that are mcriminating.

The Court had never before held nonverbal conduct to be testimonial, 218 and it did so now im a hypertechnical inanner. The Court found that a suspect's act of production could be "testimomal" in a proper case because the conduct associated with production may have "cominunicative aspects of its own, wholly aside from the contents of the papers produced."219 Contained within such conduct the Fisher Court identified three elements of implied testimony by the suspect that could have sufficient commumicative value to be of Fifth Amendinent concern.

First, the Court stated that an act of production "tacitly concedes the existence of the papers demanded."220 Presunably, this informs the

216. By requiring that governmental compulsion and the origination of a testimonial communication comcide for the self-incrimination protection to attach, the Court obliterated Boyd's contentsbased privilege. The nature of the ideas contained in any document authored voluntarily, without government coercion, had become a matter of indifference under the Fifth Amendment. The Court has yet to decide an act of production case in which the materials sought are of a highly intimate nature, such as a personal diary or a collection of love letters. Perhaps the vestiges of a contentsbased privilege might be found to exist in such a ease, but there is little in Fisher or later act of production decisions to support this view. See Doe I, 465 U.S. at 618 (O'Connor, J., concurring) ("I write separately ... to make explicit what is imphicit in the analysis of [the majority] opinion: that the Fifth Amendment provides absolutely no protection for the contents of private papers of any kind."). Assuming that no contents-based Fifth Amendment privilege can be found for such cases, some have suggested that a First Amendment protection should be developed to shield private writings from the government. See Friendly, supra note 39, at 703.

217. See Fisher, 425 U.S. at 410-11.

218. Before Fisher, the Court had considered, but rejected, claims that specific forms of nonverbal conduct could be testimony under the Fifth Amendment. See, e.g., United States v. Wade, 388 U.S. 218 (1967) (standing in lineup); Schmerber v. California, 384 U.S. 757 (1966) (giving blood sample).

219. Fisher, 425 U.S. at 410; see also Doe II, 487 U.S. at 209 ("[T] he Fifth Amendment privilege against self-incrimination applies to acts that imply assertions of fact."); Doe I, 465 U.S. at 612 ("Althougl the contents of a document may not be privileged, the act of producing the document may be.").

220. Fisher, 425 U.S. at 410. 
government that the evidence sought is not purely imaginary and also that it presently exists: i.e., it has not been destroyed. Second, production reveals that the suspect has possession of the evidence, or at least has sufficient control over it to make it available to the government. 221 Finally, the act of production communicates the suspect's behef that the thing produced meets the description of the evidence as stated in the government's request, and can thereby aid in the authentication of the evidence. 222

One might suppose that soine of these testimonial elenients will inevitably be present in every act of production of evidence by a criminal suspect. It is difficult to imagine a case where production could be accomplished without tacit admissions going at least to the elements of "existence" and "possession or control."223 Curiously, however, the Fisher Court ruled that the testimionial elenents required to claim the privilege are present only im some cases, or can ouly sometimies be deenied sufficiently incriminating to fall within the Fifth Amendment. ${ }^{224}$ Their presence or absence, together with sufficient indicia of mcrimination, are matters to be adjudicated on the "facts and circumstances of particular cases or classes thereof."225 In the case before it, the Fisher Court apphied this facts-and-circunistances test to find that the three testimonial elements would not be present in a hypothetical act of production by the taxpayers, or else would not be sufficiently incriminating to the taxpayers to raise constitutional concern; it thus concluded that production would not imtrude upon the taxpayers' Fifth Amendment rights. ${ }^{226}$

With respect to the testimonial elements of "existence" and "possession or control," the Court found that the existence of the workpapers at issue, as well as the taxpayers' control over them, were "foregone conclusions" already known to the government prior to any act of production by the taxpayers. ${ }^{227}$ Unfortunately, the Court did not explain what a

221. Id.

222. Id.

223. It is possible to imagine a production that would not authenticate a document, as when the suspect has no idea who authored a memorandum in her possession. However, even in such a case, production would reveal the suspect's belief that the memorandum is the document described in the subpoena.

224. Fisher, 425 U.S. at 410.

225. Id. This aspect of Fisher has proved problematic, largely because it is exceedingly difficult to track how the Court expected its facts-and-circumstances test to operate. For guidance, the lower courts must look to Fisher itself, which applied the test, and to Doe I, which upheld an application of the facts-and-circumstances test by the courts below. See infra Part III(A)(3). In both opinions, however, there is scarce explanation of the new concepts making up the act of production doctrine.

226. See Fisher, 425 U.S. at $410-11$.

227. See id. at 411 . 
"foregone conclusion" was, or low it may be established.228 On the facts before it, however, the Court was persuaded that existence and control were foregone conclusions because the government could demonstrate an mdependent basis for belief that the workpapers had in fact been created and that the taxpayers liad the power to produce them. The Court ruled that under such circumstances, any implicit admissions of existence and control associated with the act of production were too imsubstantial to be considered "testimomal" within the Fiftl Amendment. 229

In the alternative, even if the taxpayers' adımssions of existence and control were assumed to have "some minimal testimonial significance," the Court also found that bare assertions of the existence of tax workpapers and the taxpayers' control over them were not by themselves evidence of illegal conduct, and could not, standing alone, be understood to pose "any realistic threat of incrimination" to the taxpayers. ${ }^{230}$ Thus, even assuming that the contents of the records miglit be enormously incriminating, limited adımissions going only to existence and control would not be. ${ }^{231}$

With respect to Fisher's third testimonial element of authentication, the Court also found on the facts that the taxpayers' passivity rights would not be implicated by compelled production of the workpapers. The Court based this conclusion on its belief that the taxpayers were not competent to authenticate the workpapers at trial because they themselves had not prepared the papers and could not vouch for their accuracy. ${ }^{232}$ Therefore, any implied expression of belief by the taxpayers that the documents produced met the descriptions set forth in the summonses would not "represent a substantial threat of self-incrimination."233 In contrast to its treatment of the elements of existence and control, the Court did not find an insufficient quantum of "testimonial" conduct witl respect to implied admissions going to authentication; ratler, the defect

228. The Court neither defined the term nor specified the government's burden of proof to show a foregone conclusion. For a discussion of the problems that arise in trying to apply the foregone conclusion concept, see infra Part III(B).

229. The Court's phraseology was that such admissions of existence and control did not "rise[] to the level of testimony within the Fifth Amendment" or were not "sufficiently testimonial for purposes of the privilege." Fisher, 425 U.S. at 411 . This language indicates that certain acts of production are not privileged because they fail entirely to be testimonial, and some are unprivileged because they are not testimonial enough.

230. Id. at 412. This portion of the Fisher opinion has not been repeated or relied upon in later Supreme Court act of production cases.

231. Id.

232. Professor Mosteller has argued that this conclusion was incorrect as a matter of evidence law. See Mosteller, supra note 183, at 16-17.

233. Fisher, 425 U.S. at 413. 
in this portion of the taxpayers' Fifth Amendment claim was solely a failure to show that meaningful incrimination might result.

In summary, the Fisher Court found that all three potential testimonial elenients of the taxpayers' act of production were absent because they were either insufficiently testimonial or insufficiently incriminating. Thus, the hypothetical conpelled acts of production by the taxpayers would fail to convey any communications that enjoy Fifth Amendment protection. Therefore, the simulated privilege was not available to taxpayers' counsel, and the IRS summonses to the lawyers could be enforced. ${ }^{234}$

3. United States v. Doe (Doe I) and the Immunity Loophole. Eight years after Fisher, the Court demonstrated in United States v. Doe (Doe I) ${ }^{235}$ that a suspect's assertion of the act of production privilege could succeed in a proper case. ${ }^{236}$ It is still the only case decided by the Supreme Court upholding an assertion of the privilege.

Doe $I$ imvolved five grand jury subpoenas served upon Milton Reid, the owner of several sole proprietorships and the target of the grand jury's investigation into alleged corruption in the award of local government contracts. ${ }^{237}$ The subpoenas commanded Reid to produce business records relating to his comparies. ${ }^{238}$ The district court quashed the subpoenas on the basis of Fisher's act of production privilege, an order that was upheld by the Third Circuit and ultimately by the Supreme Court. ${ }^{239}$ Relying on Fisher, the Doe I Court said that although the contents of the subpoenaed records were not privileged in theniselves, the act of producmg them may be. ${ }^{240}$ The Court reiterated that the relevant concerns, under a facts-and-circumstances test, were whether the act of production by Reid would be sufficiently testimonial, whether it would convey only foregone conclusions, ${ }^{241}$ and whether it would be sufficiently incriminating. ${ }^{242}$

234. Id. at 396.

235. 465 U.S. 605 (1984).

236. Doe $I$ did not involve production sought froin counsel and thus presented no issue concerning the simulated privilege created in Fisher.

237. See In re Grand Jury Einpaneled March 19, 1980, 541 F. Supp. 1, 1-2 (D.N.J. 1981), aff'd, 680 F.2d 327 (3d Cir. 1982), aff'd in part and rev'd in part sub nom. Uinited States v. Doe (Doe I), 465 U.S. 605 (1984).

238. Doe $I, 465$ U.S. at $606-07$.

239. The Court reversed the lower courts' rulings to the extent that they rested upon a theory that Reid could assert a contents-based privilege. See id. at 617 n.18.

240. See id. at 612 .

241. As in Fisher, the Doe I Court offered no guidance as to the nature of the prosecution's burden to deinonstrate a "foregone conclusion."

242. Doe $I, 465$ U.S. at 612-13. 
Having proceeded this far, the Court cut its analysis short with the observations that the district court below had made an explicit finding that the act of production by Reid would involve testimonial self-incrimination, and that the court of appeals had agreed. ${ }^{243}$ The Doe I Court stated that it would not overturn this factual finding unless it was unsupported in the record. ${ }^{244}$ In a footnote, the Court reviewed Reid's allegations and found them sufficient to "establisls a valid claim of the privilege" as determmed by the courts below. ${ }^{245}$

The Doe I Court went on, lowever, to say that a successful assertion of the act of production privilege by a suspect does not wholly foreclose the government from enforcing its subpoena and obtaining the requested evidence. To compel compliance, all the government need do is grant statutory use immunity to the suspect under 18 U.S.C. $\S \S 6002$ and 6003 , which are sufficient to cover any incriminatory effect of the act of production. ${ }^{246}$ Following sucl a grant of immunity, the suspect can no longer interpose a Fiftl Amendment objection to compliance with the subpoena. Rather, the suspect must produce the evidence deniandedsubject to the assurance that the government will not be permitted to make direct or derivative use against him of any testimonial aspects of his act of production. ${ }^{247}$

One of the most enduring of Fisher's mysteries is the legal effect that will be given a grant of use immumity for the act of production. Fifteen years after Fisher, no reported decision lias yet defined the scope of such immumity. ${ }^{248}$ In theory, its outlines might be discerned througlı a study

243. See id. at 613.

244. See id. at 613-14.

245. Id. at $614 \mathrm{n} .13$. Little can be gleaned from footnote 13 's discussion, which is short and conclusory. The Court noted that the existence and possession of the requested records had not been conceded by Reid, and that these facts would be tacitly admitted through the act of production. The Court also said that Reid's production would authenticate the papers. Finally, the Court said that the government had not been foreclosed from "rebutting" Reid's claim of privilege by "producing evidence" that existence, possession, and authentication were "foregone conclusions," but had failed to make such a "showing" in this case. Id. The Court gave no further content to its foregone conclusion concept.

246. See id. at 614-17.

247. Section 6002 provides that once the court has entered an order conferring immunity and requiring the witness's testimony, "the witness may not refuse to comply with the order on the basis of his privilege against self-incrimination." 18 U.S.C. $\$ 6002$ (1988). The statutory immunity is thought to give full protection to the witness against self-incrimination, thus leaving no basis upon which he can refuse to testify. See Pillsbury Co. v. Conboy, 459 U.S. 248, 254-55 (1983).

248. The cases that speak to the issue at all involve the propriety of granting an immunity order in the first place, rather than deciding what the scope of the immunity will be when tested in a later proceeding. See In re Grand Jury Proceeding, Special April 1987, 890 F.2d 1, 4 (7th Cir. 1989) (stating that discussion of the scope to be given use immunity in act of production case is "premature"); In re Sealed Case, 791 F.2d 179, 182 (D.C. Cir.) (deferring question of scope of use for a subsequent suppression hearing), cert. denied, Wiggins v. United States, 479 U.S. 924 (1986); United 
of use immunity in general, in settings where oral testimony is immunized. In such cases, the protections offered under the immunity statute are required to be "coextensive" with the Fifth Amendment rights at stake. $^{249}$ The government calmot niake overt use of immunized testinony by imtroducing it against the suspect in any subsequent criminal case. 250 In addition, the government cannot make derivative use of immunized testimony to develop leads or other information to be used against the suspect. ${ }^{251}$ The guiding principle is that the government and the immunized witness should be left in "substantially the same position as if the witness had claimed the Fifth Amendment privilege" with respect to the immunized testimony. ${ }^{252}$ In any subsequent prosecution of the suspect, the government bears a "heavy burden" of proving that all of the evidence it proposes to use against the suspect was derived fron legitinate independent sources. ${ }^{253}$

Putting this estabhshed theory imto practice under Fisher is not easy. Because the testimonial components of the act of production privilege are highly abstract, the meaning of an immunity that is "coextensive" with the privilege is open to great debate. Two polar views illustrate the problen1. Justice Marshall, concurring in Fisher, argued that immunity for the act of producing evidence will normally foreclose any subsequent use of the evidence against the suspect, because such use would derive fronı the fact of its existence, which is one of the admissions included within the immunized testimony. 254 Thus, the contents of any document produced under immumity could not be used by the prosecution, either in the

States v. McCollom, 651 F. Supp. 1217, 1223-24 (N.D. Ill.) (same), aff'd, 815 F.2d 1087 (7th Cir. 1987).

249. See Kastigar v. United States, 406 U.S. 441, 453, 462 (1972).

250. The statute provides exceptions for later prosecutions for perjury, giving a false statement, or otherwise failing to comply with the order granting immunity and requiring that the testimony be given. See 18 U.S.C. $\$ 6002$ (1988).

251. Section 6002 provides in part that "no testimony or other information compelled under the order (or any information directly or indirectly derived from such testimony or other imformation) may be used against the witness in any criminal case." Id. See also Kastigar, 406 U.S. at 453-54, 460 (stating that the government cannot use, directly or indirectly, the compelled testimony of a witness against that witness in a later criminal proceeding).

252. Kastigar, 406 U.S. at 462.

253. Id. at 461-62. This "heavy burden," however, may be no more than a requirement of proof by a preponderance of the evidence. See Umited States v. North, 920 F.2d 940, 952 (D.C. Cir. 1990) (Wald, C.J., dissenting), cert. denied, 111 S. Ct. 2235 (1991).

254. See Fisher, 425 U.S. at 433-34 (Marshall, J., concurring). On the other hand, it could be argued that a physical object bespeaks its own existence, and that the object itself therefore provides independent proof of existence without reliance upon the suspect's immunized testimony. If so, however, it makes hittle sense that Fisher and later Courts took the trouble of mentioning testimonial communications going to the existence of evidence as one basis for Fifth Amendment protection. 
courtroom or to develop leads, because "the contents are a direct fruit of the immunized testimony-that the document exists."255

At the opposite extreme, the Court of Appeals for the First Circuit has, in dictum, taken a narrow view of the effect of use immunity in a Fisher-type case. Under the First Circuit theory, the contents of documents procured under a grant of act of production immunity can always be used agamst the person who produced them. This is because, under Fisher, the contents of voluntarily created records are not viewed as compelled commuirications, and therefore those contents must fall outside any immunity protection that is merely coextensive with the Fifth Amendment privilege. ${ }^{256}$ The Supreme Court gave the First Circuit view a powerful shot in the arm when it dropped a footnote in Doe I stating, in dictum, that it found the argument "unfounded" that a grant of use immunity would cover the contents of documents as well as the act of production itself. ${ }^{257}$

255. Id. at 434. For a similar approach, see Mosteller, supra note 183, at 43-49.

256. See In re Grand Jury Proceedings (Martinez), 626 F.2d 1051, 1058 (1st Cir. 1980); see also Note, The Rights of Criminal Defendants and the Subpoena Duces Tecum: The Aftermath of Fisher v. United States, 95 HARV. L. REv. 683, 688-90 (1982) (endorsing the First Circuit view of act of production immunity). The difference between the Marshall and First Circuit theories reduces to differing views of the significance of the testimonial elenent of existence under Fisher. The Martinez court said that "in most cases" any implied testimony as to the existence of requested documents "will be so trivial that the Constitution is not implicated." 626 F.2d at 1055. In contrast, Justice Marshall's broad view of act of production innunity turns upon taking seriously the element of existence where it is in question. See Fisher, 425 U.S. at 434 n.2 (Marshall, J., concurring).

At least two circuit courts have expressed doubts about the adequacy of Martinez's concept of use immumity. See In re Grand Jury Einpaneled March 19, 1980, 680 F.2d 327, 337-38 n.20 (3d Cir. 1982) (quoting Justice Marshall's concurrence in Fisher), aff'd in part and rev'd in part sub nom United States v. Doe (Doe I), 465 U.S. 605 (1984); United States v. Porter, 711 F.2d 1397, 1402-04 (7th Cir. 1983) (stating that use immunity as conceived in Marinez inust be supplemented with an additional proteetive order "forbidding the governnent from referring in any way before the grand jury or at trial to the fact that [the defendant] produced the documents").

257. Umited States v. Doe (Doc I), 465 U.S. 605, 617 n.17 (1984). Putting the element of "existence" aside, the First Circuit is surely correct that act of production inınunity would have little effect upon the government's use of the evidence itself. With respeet to the testinionial element of "possession or control," the only assertion nuade by a suspect through the act of production is that "I presently have the power to produce this thing." This in turn is the only communication that is immunized, and a bar against the government's use of such infornation does not support an argument that the evidence standing by itself cannot be used. This facet of use inununity for the act of production is analogous to the rule of exclusion of evidence developed in the Olwell cases. See supra Part II(A)(1).

As to the testinonial elentent of "authentication," act of production imnunity would extend only to the suspect's iniplied assertion of belief that the object produced is the thing denianded in the subpoena. Provided that the government relies upon independent sources for this infornation during its investigation, and does not offer the suspect's act of production to establish such information at trial, the immumized coninunication as to authentication would not be invaded by the use of the evidence itself during the investigation or in a later court proceeding. 
The weight of the act of production privilege recognized in Fisher is poised upon the unresolved immunity issue. If act of production immunity can be granted with hittle or no cost to successful prosecutions (the First Circuit view), its widespread use would render the suspect's selfincrimination privilege with respect to the production of evidence a matter of small consequence. On the other hand, an expansive view of act of production immunity (Justice Marshall's view), would ensure that the act of production doctrine operates as a meaningful constitutional protection against conipelled production of evidence in a large number of cases. ${ }^{258}$

\section{B. Can Fisher and Olwell Coexist?}

The simulated and act of production privileges recognized in Fisher, although still undefined in many important respects, have clear bearing upon the problems of lawyers' production of chent-incriminating evidence under Olwell and its progeny. On its facts, Fisher is directly, albeit implicitly, contrary to the Olwell rule. If we assume that the tax workpapers at issue in Fisher were potentially mcriminating to the taxpayer chents, a straightforward application of Olwell or Morrell would have required the defense lawyers to come forward with the documents after some reasonable interval, with or without a specific legal command to do so. The failure of the parties and the courts in Fisher to raise the Olwell rule strongly suggests an accepted view that the defense lawyers had no self-activating duty to produce the tax records. ${ }^{259}$ Indeed, the protracted Fisher hitigation would have been an idle exercise if the attorneys had all along been subject to the Olwell duty. ${ }^{260}$

Fisher and Olwell cannot coexist. Assuming for the moment that Fisher is the bettex or controlling precedent, it invalidates a substantial

258. The dearth of precedent on this issue is surprising given the great potential of act of production immunity as a proseeutorial tool. Government lawyers should be (but apparently are not) seeking out test cases to explore the possibility that such immunity will permit access to heretofore unavailable physical evidence of all kinds, with relatively little cost to effective prosecutions.

259. Cf. United States v. Ross, 456 U.S. 798, 819 (1982) (Earlier decisions that assunied, without the issue being raised, that searclies of containers within vehicles were permissible without a warrant " 'liave nucli weiglit, as they show that this point neither occurred to the bar or the bencli.' The fact that no sucl argument was even niade illuininates the profession's understanding of the scope of the search permitted under Carroll.") (quoting Bank of the United States v. Deveaux, 9 U.S. (5 Cranch) 61, 88 (1809) (Marshall, C.J.)).

260. In Olwell, the court found a subpoena direeted to a lawyer infirm, but still lield that, after a rcasonable time, the attorney was obliged to cone forward with the evidence on lis own motion. See Olwell, 394 P.2d at 684-86. This result is anomalous. It makes little sense to allow counsel to fight tootl and nail to fend off legally comipelled production-a battle that we now understand under Fisher to implicate Fiftl Amendinent principles-if we sinultaneously believe that the lawyer lias no proper basis for withholding the evidence in the first place. 
portion of the Olwell rule. To explore this thought, it is useful to reconsider the Olwell case as though it had arisen today, in a court bound to follow the teachings of Fisher.

1. Relitigating Olwell. We return to the Olwell storyline after Olwell has been given a knife by his client Gray. We may recall that Olwell has been served with a subpoena to produce the knife, althougli the importance of this is obscure since the original Olwell court found that the lawyer had a wholly imdependent obligation to come forward with the evidence. In any event, the attorney must decide what objections to raise to tlie subpoena and wliether or not he must produce tlie knife on his own motion, irrespective of the subpoena.

Attorney Olwell, now well familiar with the twin holdings of Fisher, would contest the validity of the subpoena on grounds different than those he argued in 1964. Without admitting the existence or his possession of the knife, he would assert Fisher's simulated Fifth Amendment privilege, and would claim that production of a knife (if any) received from Gray would violate his client's act of production privilege. If the prerequisites for the simulated privilege and act of production claim could be shown, the subpoena would not be enforceable absent an appropriate grant of immunity to the client. Further, based on the implicit holding of Fisher, the lawyer's ability to resist compliance with the subpoena would perforce establish that he lias no conflicting obligation to come forward on his own motion witl the same evidence.

It is plausible that the defense could successfully claim the simulated privilege if Olwell were relitigated today. Under Fisher, the privilege is available when a transfer of evidence to counsel was made by the client "for the purpose of obtaining legal advice."261 Of course, we do not really know why Gray gave the knife to lis lawyer; it is possible that, on examination, his purpose would not prove satisfactory. ${ }^{262}$ Where, for example, the client's purpose in consulting a lawyer is to further prospective criminal activity, the crime-fraud exception to the attorney-client

261. Fisher, 425 U.S. at 405; see also United States v. Tedder, 801 F.2d 1437 (9th Cir. 1986) (denying privilege to law firm associate's confession to colleague because motivated by friendship rather than desire to seek legal advice), cert. denied, 480 U.S. 938 (1987); In re Grand Jury Subpoena, 642 F. Supp. 230, 232-33 (S.D. Fla. 1986) (holding that attorney must disclose source of counterfeit money deposited as chent fees; payment of fees had nothing to do with reasons why legal advice sought); In re Vanderbilt, 439 N.E.2d 378, 387 (N.Y. 1982) (Jasen, J., concurring in part and dissenting in part) (finding no purpose to obtain legal advice when attorney never listened to cassette tapes received from client; obvious purpose was concealment).

262. The operation of the client-purpose requirement in a simulated-privilege case is hard to predict because its legal content has not been fully articulated by the courts, and because it is difficult to admimister. On the level of fact determination, the only person who knows the client's true purpose in giving evidence to counsel is the chent himself. He will seldom care to give testimony on the 
privilege would render all related communications unprotected; transfers of evidence associated with such communications would likewise lose their privileged status. ${ }^{263}$ Thus, if Gray gave the knife to Olwell because he wanted the lawyer to conceal it unlawfully, Olwell would have no basis to invoke the simulated privilege.

On the other hand, one can posit legitimate purposes that Gray might have had in giving evidence to his lawyer. Whenever a client has evidence that could be damaging to him, he will of course have an interest in keeping it out of the government's hands, but he might approach his lawyer hoping that counsel knows a lawful way to accomphish this end. Such motivation is conceivable in Fisher, where the damaging materials were tax records, ${ }^{264}$ as well as in cases like Olwell that involve nore "dramatic" physical evidence. The chent's purpose cannot be condemned as criminal unless he also contemplates that the lawyer will, if . necessary, assist in a criminal effort to conceal. A chent who lacks this additional nens rea could merely be seeking legal advice concerning his lawful rights and obligations concerning the production of the evidence.

A chent who transfers evidence to counsel may be acting for other legitimate reasons, such as the desire to familiarize his lawyer with all aspects of the case. A chent who claims innocence might turn over a knife to counsel ostensibly to seek the lawyer's aid in demonstrating that his knife was not the one used in the crime. Another client, who claims not to renieinber the events of the crime, may turn over a weapon to counsel for study and testinig, so that the lawyer can help him assess what really happened. ${ }^{265}$ Even in the case of a chent who has admitted guilt to his lawyer, transfer of a knife to counsel might occur so that the lawyer can advise the chent how damaging the weapon will be, and answer the client's most urgent question: "What should I do?" After examining the knife, the lawyer may be able to tell the chient whether the government

matter, however, nor can he be required to do so. Conceivably, the attorney may be compelled to disclose her version of the events in camera for the purpose of determining the availability of the privilege. See Umited States v. Zohn, 491 U.S. 554, 565 (1989) (permitting district court in some cases to make in camera review of materials allegedly falling within the attorney-chent privilege to determine whether those commumications fall within the crime-fraud exception). However, counsel does not know what her chent was thinking and can usually supply only circumstantial evidence as to the client's purpose.

263. See id. at 556.

264. I would wager that im most subpoena-comphiance hitigation concerning documents, the client's first priority is not an altruistic desire to uphold the strictures of the Fifth Amendment, but rather the wish to keep potentially damaging records out of the government's hands. Nevertheless, the motive of concealment is channelled into lawful Fifth Amendment argumentation.

265. This may be close to what actually happened in Olwell. At the time of the subpoena to counsel, Gray had already confessed to the murder, but evidently could not recall what knife he had used. See Olwell, 394 P.2d at 683. 
could succeed in linking the weapon to the client or the crime, and what impact the weapon imght be expected to have on the jury and the sentencing process. Even in an open-and-shut case, the lawyer's examination of damaging evidence can lead to ineaningful legal advice. That advice inay indeed be: "I think we should negotiate a guilty plea as soon as possible," but this is still legal advice, and it is the kind of advice that the attorney-chent privilege should encourage.

A cautionary note is important here: There are many cases of the Olwell variety where the client-purpose requirement could never be met simply because the chent is not the source of the evidence received by counsel. By its own terms, Fisher's simulated privilege applies only to client-source material and does not reach evidence that lias come into the hands of the defense attorney from third parties or as a result of an independent investigation. This is consistent with the general terms of the attorney-chient privilege, which protects only communications between "privileged persons"-typically the lawyer and the client. ${ }^{266}$ Because of this restriction, all of the Olwell cases that involve nonchent-source evidence remaim untouched by the holdings of Fisher. ${ }^{267}$

Let us return to our latter-day Olwell case and assume that the required showing has been made that Olwell received the knife from Gray, who in turn acted with the required purpose of seeking legal advice in inaking the transfer to his lawyer. Under these assumptions, the lawyer has met the threshold requirements of the simulated privilege. The next issue in the case, as in Fisher, will be whether the client himself could resist compelled production of the knife with a claim of passivity rights under the act of production doctrime. Now the case turns upon a determination of whether a hypothetical compelled production from

266. See infra Part $\mathrm{III}(\mathrm{C})(1)$.

267. Morrell's holding, for example, survives Fisher because defense counsel received the kidnap plan from his client's friend, not from Morrell himself. See also Vanderbilt, 439 N.E.2d at 386 (according simulated-privilege protection to cassette tape inade by client only if attorney received it through client or client's agent). On the same reasoning, documentary material in a white-collar case would fall outside Fisher's protection if it did not pass to the lawyer through the client. Any harmful records gathered during counsel's investigation and received froin her client's business associates, employees, or from the files of a corporation or partnership, are unprotected by the simulated privilege.

It might be possible, although cumbersoine, for defense counsel to bring herself within the simulated privilege by undertaking leer investigation in a way that shields her froin taking possession of any potential evidence until it can be filtered through the hands of the client. If the client is incarcerated, of course, such a process may prove inpossible. The device also seems a pointless and silly exercise for the law to require. Nevertheless, if we are to take Olwell and Morrell seriously, it is an idea that merits study by defense counsel. 
Gray would elicit testimonial and potentially incriminating communications. ${ }^{268}$

Quickly we are embroiled in the technical abstractions of Fisher. Attorney Olwell would argue that production by Gray would implicitly communicate that the knife actually and still exists, that Gray has present possession of or control over it, and that Gray's production would supply information contributing to the eventual authentication of the knife in court. The government would in turn contend that, on the facts and circumstances of this case, any such assertions going to the existence, possession or control, and authentication of the knife are foregone conclusions, or would not be sufficiently mcriminating to be of Fifth Amendment concern.

How would such arguments unfold? Beginning with the testimonial elenient of the knife's existence, the chient's claim of privilege could rest on one or both of the following arguments:

(1) The government cannot demonstrate that it knows as a certainty 269 that the requested knife ever really existed. Therefore, this fact is not a foregone conclusion under Fisher and compelled production by Gray would supply testimonal, incriminating information to the government.

(2) The governinent cannot deinonstrate that it knows as a certainty that the knife presently exists, that is, that it has not been destroyed. Therefore, as above, this information is not a foregone conclusion.

In litigating these issues, much will depend on how much the prosecution already knows about the evidence it has requested. For example, where requested evidence is in public view, or where a government informant is able to niake a conteinporaneous report of its existence, the governnient could denionstrate independent knowledge of present existence. In soine cases, there niay even be an adnission or stipulation from the defense going to present existence. ${ }^{270}$

A critical issue, to date unresolved by the courts, is the burden of proof borne by the government in demonstrating that a particular testimonial fact is indeed a foregone conclusion. The Supreine Court has applied the concept only in Fisher and Doe I, and did not speak to the

268. Under Fisher's simulated privilege, the imagined event of compelled production from the client supplies the facts to be tested under the Fifth Amendment. See supra Parts III(A)(1) \& (2).

269. For reasons discussed infra, the "certain knowledge" standard of proof may not be adopted by the Court in foregone conclusion determinations. I have borrowed it from the Third Circuit's decision in In re Grand Jury Empaneled March 19, 1980, 680 F.2d 327, 335 (3d Cir. 1982), aff'd in part and rev'd in part sub nom. United States v. Doe (Doe I), 465 U.S. 605 (1984).

270. In upholding an assertion of the act of production privilege, the Supreme Court in Doe $I$ noted that there had not been such a stipulation by the defense. See Doe I, 465 U.S. at 614 n.13. 
burdens issue in either case. The Third Circuit in Doe I, however, suggested that a foregone conclusion can be established only when the government "knows, as a certainty" the testimonial fact that will be conveyed by the suspect's act of production. ${ }^{271}$ I have borrowed this language in formulating arguments (1) and (2) above, but the Suprene Court in Doe I did not expressly endorse the lower court's view of the applicable burden. It reniains possible that a lower standard, such as knowledge establislied by a preponderance of tle evidence, may ultiinately be adopted by the Court. 272

Fron tlie government's perspective, ineeting its burden as to proposition (1) is likely to be easier than proving proposition (2). There niay be witnesses wlo have seen the knife in the past, sales receipts, photographs, or otler sources of information that show the particular knife at issue is not fictional. Depending on the government's burden of proof, such information miglit be sufficient to denionstrate the government's knowledge of the knife's past existence. This, however, carmot by itself satisfy the foregone conclusion standard as to continuing existence. Proof that the knife existed six inonths or two weeks ago does not establish that it has not been destroyed in the meantime. Unless there is proof or a defense concession going to present existence, it is unlikely that the foregone conclusion standard as to the testimonial elenient of existence could be net. 273

271. See In re Grand Jury, 680 F.2d at 335.

272. In other areas of constitutional criminal procedure, the Court has created tests to be satisfied by the government with formidable names but that in application have a bite falling short of their bark. For example, the Court articulated an "inevitable discovery" exception to the fruit-ofthe-poisonous-tree doctrine in Nix v. Williams, 467 U.S. 431 (1984), but the government need only prove "inevitability" by a preponderance of the evidence. See also Colorado v. Connelly, 479 U.S. 157, 168 (1986) (holding that government's "heavy burden" of demonstrating a suspect's waiver of Miranda rights requires proof of waiver by a preponderance of the evidence).

There is no analogue to the foregone conclusion concept elsewhere in Fifth Amendment jurisprudence. Normally, an otherwise sufficient claim of the self-incrimination privilege could not be overcome by a showing that the governinent already knows the incriminating information that the suspect is now called upon to supply. See Fisher, 425 U.S. at 428-29 (Brennan, J., dissenting) ("I know of no Fifth Amendment principle which makes the testimonial nature of evidence and, therefore, one's protection against incriminating himself, turn on the strength of the Government's case against him."). The anomalous nature of the foregone conclusion test, together with the importance of the rights at stake, suggests that a heavy burden should be imposed on the government.

273. Again, a manipulation of burdens might help the government here. It might be argued that proof of past existence, particularly in the recent past, creates an inference or even a presumption of continued existence, so that the burden is shifted to the suspect to come forward with proof that the subpoenaed evidence no longer exists. 
The breakdown of factual issues is similar for the question of whether Gray's possession or control can be shown to be a foregone conclusion. The government may be able to demonstrate that Gray had possession of the subpoenaed knife at some point in the recent or distant past, but it is a formidable task to prove that such possession has been inaintained to the present. Again, without a concession by the defense, it nay be quite difficult for the government to show that the suspect has not lost or discarded the requested item, or relinquished control to someone else.

Finally, the contemporary Olwell court would be required to pass upon the testimonial element of authentication. Here, more than with existence and control, the wording of the subpoena is a critical variable because the chent is asked to endorse the description of the item in the subpoena by responding and turning over an object that ineets that description. ${ }^{274}$ For exainple, production of a knife under the actual Olwell subpoena would carry Gray's unspoken admission that, "I believe this is a knife that relates to me or to the victim."275 Production under a different, very specific subpoena might admit only that, "I believe this is a Model ABC hunting knife with a broken handle and the word 'Gray' written on it." Whatever the nature of the admission elicited by the subpoena's terms, the government must show that the datum is a foregone conclusion, or else would not serve to imcriminate the client.

Following Fisher's example, a court may find that Gray's implied admissions regarding authentication are of no constitutional concern unless they are adequate in themselves to authenticate fully the knife at trial. ${ }^{276}$ Alternatively, the government inay claim that it has means wholly independent of Gray's adınissions to authenticate the knife. Perhaps a witness, a sales receipt, or fingerprints on the knife could establish a link between the knife and Gray that would otherwise be revealed solely by Gray's act of production. Again, much will depend on the burden of proof developed for such cases, as well as the extent of the government's knowledge regarding the knife before the subpoena was served.

Considering all of the above arguments, it is not farfetched to suppose that the defense might prevail under an act of production analysis in establishing Gray's passivity right to withhold production of the weapon. It even seems fair to say that the government would normally face an

274. See Mosteller, supra note 183, at 10-15.

275. See supra Part II(A)(1). Because the subpoena was directed to counsel, production would also admit that the knife had somehow found its way into the lawyer's possession.

276. In these circumstances, the Fisher Court concluded that admissions relating to authentication do not represent a "substantial threat of self-incrimiuation." See 425 U.S. at 413. 
uphill battle in such hitigation given that the foregone conclusion standard denands an extensive portfolio of pre-production information concerning the requested evidence. Naturally, the number of cases won and lost by the government will depend to some extent on what burden of proof is ultimately imposed for foregone conclusion determinations. However, even if a relatively low standard is adopted (such as proof by a preponderance of the evidence), the government will have much work to do.

Of course, the Court in Doe $I$ inade clear that a subpoena is not rendered finally and forever unenforceable inerely because a suspect has estabhished a Fifth Amendment passivity right to resist production. The governinent always holds the trump card of use immunity in an act of production case, and can force production froin the lawyer in a case like Olwell by granting immunity to the client. In bestowing such inımunity, however, the prosecution risks losing the use of the knife in later proceedings against Gray, and opens itself to the clain that later-developed evidence should be excluded as derivative of immunized information. ${ }^{277}$ If act of production immunity grows nito the formidable slield envisioned by Justice Marshall, ${ }^{278}$ it will seldorn prove a useful nieans for prosecutors to bypass a suspect's passivity rights. On the other hand, act of production immunity could also prove to be a low-cost tool for the government. If narrowly construed along the lines advocated by the First Circuit, ${ }^{279}$ meaningless iminunity grants would largely eviscerate Fisher's passivity rights for the production of physical evidence. Under such an approach, the evidence produced by the suspect or the suspect's lawyer could itself always be used in a later prosecution of the suspect. Only evidence concerning the circunistances of its production would be immunized. This would render application of the act of production privilege under Fisher similar to the operation of the Olwell rule, where the evidence itself is produced to the government and admissible at trial, subject ouly to a rule of exclusion for testiniony concerning the circuinstances of production. ${ }^{280}$

One inajor concern remains in our reevaluation of Olwell under the tenets of Fisher. The act of production analysis presented above will be of no avail in inost Olwell cases if Fisher's act of production doctrine is

277. See, e.g., United States v. North, 920 F.2d 940, 952 (D.C. Cir. 1990), cert. denied, 111 S. Ct. 2235 (1991).

278. See supra Part $\operatorname{III(A)(3).~}$

279. See supra Part III(A)(3).

280. For a discussion of the operation of Olwell's rule of exclusion, see supra Part II(A)(1). 
found to apply only to documents. ${ }^{281}$ Technically this possibility remains open, as the Supreme Court has never decided an act of production case that involved physical evidence other than documents. The analysis of Fisher and later cases, however, strongly suggests that all varieties of evidence will be imcluded.282 Prior to Fisher and Doe, it may have been supportable to say that application of the self-incrimination clause turned upon the nature of the evidence sought by the government. A private paper was not vulnerable to process because its contents were considered testimonial; the same could hardly be said of a weapon or many other varieties of physical evidence that contain no verbal record of a suspect's ideas. After Fisher, however, the testimonial nature of the evidence itself is no longer relevant to the Fifth Amendment analysis. ${ }^{283}$ The focus has shifted to the act of production rather than the thing produced. Under this theory, there is no reason to suppose that the implicit testimony surrounding the production of a weapon is of any less constitutional concern than the equivalent imphed adimssions surrounding the production of a record.

The few cases that have confronted this issue have endorsed the extension of the act of production privilege to evidence other than documents, and even to "drainatic" evidence of the kind considered in Olwell. In Commonwealth v. Hughes, ${ }^{284}$ the Massachusetts Suprenie Judicial

281. The chent-purpose requirement might also provide an argument that Fisher's simulated privilege should be restricted to documents, while the Olwell rule would continue to apply to other forms of evidence. The Olwell court, it will be remembered, expressed a view that items like weapons and stolen property have "little, if any, material value for the purposes of aiding counsel in the preparation of the defense of his client's case." Olwell, 394 P.2d at 684 . I have argued that this is not so. See supra Part III(B)(1). Unlike Fisher, the Olwell court did not consider the client's purpose relevant to its decision and instead based its holding on a perception that the knife was simply not important to the preparation of the defense case. See Olwell, 394 P.2d at 684.

282. Recently, in Baltimore City Dep't of Social Servs. v. Bouknight, 493 U.S. 549 (1990), the Supreme Court entertained an argument that the act of production doctrine stretched so far beyond documentary evidence as to reach a court order to produce a person. Bouknight involved an order that directed a mother to produce her son, who had becn adjudicated a child in need of assistance, and whoun the State feared to be injured or dead. Bouknight asserted that her act of producing her son "would amount to testimony regarding her control over and possession of" her child, and the Court conceded that "her implicit communication of control over Maurice at the moment of production might aid the State in prosecuting Bouknight." Id. at 555. Justices Marshall and Brennan, in a separate opinion, expressed their view that Fisher applied to an order to produce a person. See id. at 562. The inajority did not hold outright that the act of production privilege could be claimed in such a situation. Rather, it merely assumed that Fisher could be invoked and rejected Bouknight's Fifth Amendunent claim on other grounds, holding that the purpose of the court order in Bouknight was essentially regulatory in character. See id. at 561.

283. See supra Part III(A)(2).

284. 404 N.E.2d 1239 (Mass.), cert. denied, 449 U.S. 900 (1980). For an earlier discussion of the interplay between Hughes and Fisher, see Lefstein, supra note 12, at 913-14. 
Court held that a court order directing the defendant to produce the gun allegedly used in an assault ${ }^{285}$ could not be enforced under Fisher:

If the defendant should produce the revolver, he would be making imphicitly a statement about its existence, location and control to which the Commonwealth says it would allude at trial to show he had possession at some point after the alleged crime. The implied statement would also function as authentication. . . . Nor would the statement amount to a "foregone conclusion" conveying merely trivial new knowledge. On the contrary, it would deal with just those matters about which the Commonwealth desires but does not have solid information. ... In the language of the cases, the Commonwealth is seeking to be relieved of its ignorance or uncertainty by trying to get itself "informed of knowledge the defendant possesses." 286

Relying heavily on Hughes, the California Court of Appeals reached the same result after a trial court ordered the defendant to turn over a gun in a prosecution for atteinpted inurder. ${ }^{287}$

The question of Fisher's application to physical evidence other than documents presents the same issues discussed in Part II(D) concerning the propriety of extending the Olwell rule to white-collar cases that involve documents. As before, there is no principled basis for constructing a rule that apphies differently to incriminating documents than to other incriminating physical evidence. Before Fisher, of course, such an arguinent could be fashioned based on the notion that the contents of private records were a species of testimonial commumication worthy of Fifth Amendinent concern, but this arguinent has been removed by the Court's new Fifth Amendment jurisprudence under Fisher and Doe I. $^{288}$ Once we are left with an inquiry that focuses solely on the act of production rather than the nature of the evidence produced, it is exceedingly difficult to restrict the privilege to documentary evidence alone.

2. Is the Simulated Privilege Based in the Constitution? Throughout Part III(B), I have indulged in the assumption that the holdings of Fisher would be followed by a present-day court grappling with a case

285. The order directed the defendant to produce a "Smith and Wesson .38 Caliber Revolver Serial Number J354354." The defendant was the registered owner of the gun. Id. at 1240.

286. Id. at 1244 (citations omitted).

287. Goldsmith v. Superior Court, 199 Cal. Rptr. 366 (Ct. App. 1984). But see In re Vanderbilt, 439 N.E.2d 378, 385 (N.Y. 1982) ("To assert successfully a claim of Fifth Amendment privilege with respect to the production of evidence, the evidence itself must be testimonial and the act of production also must include some testimonial quality.") (citing Fisher, 425 U.S. at 409-11 and S. Lumont Bossard, Jr., Note, Constitutional Law-Taxpayer's Fifth Amendment Privilege Against Self-Incrimination-Fisher v. United States, 18 B.C. INT'L \& CoMP. L. REV. 998, 1009-10 (1977)). Vanderbilt notwithstanding, the Supreme Court has never hinted that both the act of production and the evidence itself must be testimonial in nature.

288. See supra Part III(A)(2). 
modeled after Olwell. This may not be so. Fisher's view of the act of production doctrine under the Fifth Amendment is certainly binding upon the states as the minimal level of passivity protection that must be afforded criminal suspects who are personally compelled to produce evidence. To that extent, Fisher must be followed in all jurisdictions.

However, Fisher's simulated Fifth Amendment privilege, which enables the lawyer to assert the act of production rights of the chent, was not conceived in Fisher as emanating from the self-mcrimination clause. In fact, the Court took pains to locate the simulated privilege wholly outside the Constitution. The lawyer's power to object is based instead upon the federal law of evidence-a creature of statute, court rule, and common law. 289 Because of this humble origin, any state can disregard or restrict Fisher's simulated privilege simply by taking a different view of the scope of its local attorney-client privilege. Specifically, a state legislature or court could decide that the pohcies underlying their attorneychent laws do not extend so far as to safeguard and encourage the transmission of documents or other tangible evidence from chent to lawyer. ${ }^{290}$ Similarly, Congress may overrule the simulated privilege by restricting federal attorney-chent law to provide that such transfers are not protected.

State courts have generally followed the Supreme Court's lead on questions of the scope of the attorney-chent privilege and related inatters. ${ }^{291}$ Thus, even if Fisher does not bind the states to follow its holding regarding the simulated privilege, it may exert a powerful, persuasive force upon the evolution of state law. Alternatively, Fisher's simulated privilege inay possess an element of constitutionahity that went unstated by the Court in 1976. For exainple, future decisions imight find that the simulated privilege is dictated by right-to-counsel guarantees in the Sixth

289. See Fisher, 425 U.S. at 402 n.8.

290. To date, no state has exercised its freedom to define an attorney-client protection more narrowly than Fisher. In fact, the state courts that have been faced with the issue have typically purported to follow Fisher's simulated-privilege holding. See State v. Superior Court, 625 P.2d 316 (Ariz. 1981); People v. Superior Court (Fairbank), 237 Cal. Rptr. 158 (Ct. App. 1987); In re Vanderbilt, 439 N.E.2d 378 (N.Y. 1982); see also RESTATEMENT OF THE LAW GOVERNING LAWYERS $\S 119 \mathrm{cmt}$. j \& reporter's note at 106-07 (Tent. Draft No. 2, 1989) (endorsing Fisher's simulated privilege). But see State v. Jancsek, 730 P.2d 14, 24 (Or. 1986) (stating that Fisher's simulatedprivilege holding is "of no interest to us" because the attorney-chent privilege in Oregon is governed by state statute).

291. For example, the states have generally adhered to Upjohn Co. v. United States, 449 U.S. 383 (1981), regarding the operation of the attorney-client privilege when the client is a corporation. A rare exception is Consolidated Coal Co. v. Bucyrus-Erie Co., 432 N.E.2d 250 (Ill. 1982) (departing from Upjohn in adhering to the "control group test" for the corporate privilege). In the work product area, every jurisdiction has adopted some form of the work product doctrine announced in Hickman v. Taylor, 329 U.S. 495 (1947). See infra Part III(C)(1). 
Amendment and the Due Process Clause, and cannot be bypassed by the states. Or, like the procedural safeguards laid down im Miranda, the Court might someday rule that the simulated privilege is constitutionally required uuless the states develop an effective substitute mechanism for safeguarding the passivity rights of represented criminal suspects. ${ }^{292}$

At present, we can only speculate about such things. The Court takes few simulated-privilege cases, and has not spoken in fifteen years to the issue of defense lawyers' ability to resist legal commands to produce chent-imcriminating evidence. There is reason, however, to anticipate that the next major Supreme Court case is coming. As the next section illustrates, significant activity and controversy have arisen from legal command cases that fall outside Fisher's reach. The degree of ferment in the lower courts suggests that the time is ripe for the Supreme Court to step into the fray with a major ruling on the law of privileges, equal in miportance to Fisher, or to the Court's broad statements of the work product doctrine in Hickman v. Taylor, ${ }^{293}$ and the attorney-client privilege in Upjohn Co. v. United States. 294

\section{Legal Commands Not Subject to the Fifth Amendment Under Fisher}

Even in federal hitigation, where the simulated Fifth Amendment privilege exists as a component of the federal attorney-chent privilege, its protections are frequently unavailable when defense lawyers are placed under specific legal command to come forward with client-incriminating evidence or information. As shown in the preceding section, this is true for all nonchent-source evidence or information, such as the kidnap plan in Morrell that was dehivered to counsel by the client's friend rather than by the chient himself. When the simulated privilege cannot be claimed, for whatever reason, questions concerning the client's passivity rights with respect to evidence demanded from counsel disappear from the case. This section exannines cases of this type. They are growing in number and are as unconcerned for the Fifth Amendinent rights of the client as the Olwell decisions have been.

Outside the circumstances where Fisher's simulated privilege is available, the chent's passivity rights are safeguarded imperfectly, if at all, by nonconstitutional inechanisms such as the work product doctrine and rules of professional conduct directed toward prosecutors. These

292. See Miranda v. Arizona, 384 U.S. 436, 467 (1966) ("[U]nless we are shown other procedures which are at least as effective in apprising accused persons of their right of silence and in assuring a continuous opportunity to exercise it, the following safeguards must be observed.").

293. 329 U.S. 495 (1947).

294. 449 U.S. 383 (1981). 
protections are not designed to effectuate the chent's passivity rights, and fall short of equivalency with those rights. As a result, there is a growing catalogue of cases in which defense lawyers have been coinpelled to provide evidence and information to prosecutors that their chents could not have been compelled to provide under the strictures of the Fifth Amendment.

1. The Limitations of the Attorney-Client Privilege. Fisher's simulated privilege can be claimed only if evidence or information sought froin a defense lawyer was obtained in connection with a communication protected by the attorney-client privilege. An assertion of the attorneyclient privilege can fail either because the person claiming it has not shown the preconditions for the privilege, 295 or because an exception to the privilege is found to be in effect. ${ }^{296}$ Although each jurisdiction has its own definition of the attorney-chent privilege, the American Law Institute has extrapolated four basic coinponents that are generally required: "(1) A communication (2) Made between privileged persons [usually an attorney and a chent] (3) In confidence (4) For the purpose of obtaining or providing legal assistance for the chent."297 Even when these requireinents are satisfied, the courts have created exceptions to the privilege when the client's purpose in seeking the assistance of the lawyer is to further an ongoing or future crime or fraud, ${ }^{298}$ where the privilege has

295. The burden is upon the party asserting the privilege to demonstrate that its requirements have been met. See Umited States v. Schaltenbrand, 922 F.2d 1565, 1574 (11th Cir. 1991); In re Grand Jury Empaneled February 14, 1978, 603 F.2d 469, 474 (3d Cir. 1979).

296. Generally the burden of proof lies with the party claiming the exception. See Umited States v. Laurins, 857 F.2d 529, 540 (9th Cir. 1988); In re Grand Jury Investigation (Schroeder), 842 F.2d 1223 (11th Cir. 1987).

297. Restatement of the Law Governing Lawyers $§ 118$ (Tent. Draft No. 2, 1989); see also UNIF. R. EVID. 502(b) (1974) ("A chent has a privilege to refuse to disclose and to prevent any other person from disclosing confidential communications made for the purpose of facilitating the rendition of professional legal services to the chent.").

298. See Umited States v. Zolin, 491 U.S. 554, 566 (1989); RESTATEMENT OF THE LAW GovERNING LAwYERS $\$ 132$ (Tent. Draft No. 2, 1989); see also David J. Fried, Too High a Price for Truth: The Exception to the Attomey-Client Privilege for Contemplated Crimes and Frauds, 64 N.C. L. REv. 443 (1986); Earl J. Silbert, The Crime-Fraud Exception to the Attorney-Client Privilege and Work-Product Doctrine, the Lawyer's Obligation of Discourse, and the Lawyer's Response to Accusation of Wrongful Conduct, 23 AM. CRIM. L. Rev. 351 (1986). 
been waived in some fashion, ${ }^{299}$ or where a breach of the privilege is necessary for counsel's self-defense or collection of a fee..$^{300}$

Over the past decade, defense lawyers have increasingly been required to coine forward under grand jury subpoena or other legal command to produce evidence and give testimony against their clients in situations where the attorney-chent privilege has been found not to extend. ${ }^{301}$ The specific evidence and information sought from counsel varies, but it is almost always potentially inculpatory to the client. The greatest activity involves attempts by the government to learn the undisclosed identity of a lawyer's client, to uncover fee arrangements and transactions between lawyer and chent, and to learn the identity of any third-party benefactor who may be paying the fee for a given client. ${ }^{302}$

299. See Restatement of the LAW Governing LawYers $\$ 129$ (Tent. Draft No. 2, 1989) ("The attorney-client privilege of a client is waived if the client, the client's lawyer, or anotlier authorized agent of the chient substantially discloses the communication in a non-privileged communication."). Unlike a constitutional privilege, the attorney-client privilege can be waived even though the privilege holder does not do so "knowing and intelligently." See EDNA S. EPSTEIN \& MICHAEL M. Martin, The Attorney-Cuient Privilege and the Work Product Doctrine 60 (2d ed. 1989). Cf. Miranda v. Arizona, 384 U.S. 436, 492 (1966) (requiring knowing and intelligent waiver of Miranda rights); Johnson v. Zerbst, 304 U.S. 458, 464 (1938).

300. See Restatement of the Law Governing LaWyers $\$ 133$ (Tent. Draft No. 2, 1989) (Exceptions for Lawyer Self-Protection); see also United States v. Omni Int'l Corp., 634 F. Supp. 1414, 1420 (D. Md. 1986); Model Code of Professional Responsibility DR 4-101(C)(4) (1980); MODEl Rules of Professional Conduct Rule 1.6(b)(2) (1988).

301. See Willcox, supra note 5, at 940 . Authors Stern and Hoffnıan recount the following history of attorney subpoenas:

In the criminal context, prior to 1980 , federal prosecutors generally believed that lawyers were not potential sources of information in criminal investigations. Subpoenas to lawyers were rare and the government was generally not successful in enforcing then. However, Justice Department officials in the Rcagan administration recxamined traditional assumptions about attorney subpoenas as they formulated aggressive approaches to crininal investigation. They concluded that prosecutors had wrongly assumed this investigative technique to be unavailable. The Department then took the position that the attomey subpoena was a "new investigative tool" that could be used if nonprivileged information in the liands of the attorney could be identified. ... The result lias been an explosion of subpoenas to lawyers, based upon aggressive and imaginative exploitation of arguable exceptions to the attorney-client and work-product privileges.

Stern \& Hoffman, supra note 5, at 1787-88 (footnotes oinitted).

302. See, e.g., In re Grand Jury Subpoena (DeGuerin II), 926 F.2d 1423 (5tlı Cir.), cert. denied, 111 S. Ct. 1581 (1991) (holding that attorney-client privilege bars disclosure of identity of client who has paid legal fees for another chient in narrow circuinstanees where disclosure would reveal benefactor/client's reasons for seeking representation in first place); In re Grand Jury Matter (Doe I), 926 F.2d 348, 351-52 (4th Cir. 1991) (uplolding grand jury subpoena to attomey for all documents concerning fee transactions with client who is subject of criminal net worth tax investigation); In re Grand Jury Subpoena (DeGeurim I), 913 F.2d 1118, 1127 (5th Cir. 1990) (enforcing subpoena to attorney to appear before grand jury and produce records concerning the fee arrangements with client); In re Grand Jury Subpoena (Anderson), 906 F.2d 1485, 1489, 1498 (10tll Cir. 1990) (enforcing grand jury subpoenas to attorneys, requiring thein to reveal the source of payment of fees for their representations for four defendants on drug charges); In re Grand Jury Proceedings 88-9 (MIA) (Newtou), 899 F.2d 1039, 1043 (11th Cir. 1990) (upholding subpoena to defense attorney to disclose client identity and fec information); In re Grand Jury Proceeding (Clerney), 898 F.2d 565, 
Subpoenas that advance such inquiries typically demand oral testimony from the lawyer as well as the production of relevant documentary evidence. ${ }^{303}$ In addition, defense lawyers are commanded by federal statute $^{304}$ to report to the IRS certain inforniation concerning any chent who makes a cash payment to the lawyer in excess of $\$ 10,000.305$ The lawyer must report on IRS Form 8300 the fact and manner of the payment, the identity and whereabouts of the client, and the reason for the payment. ${ }^{306}$ Such reporting obligations exist in the absence of a subpoena or summons, or any ongoing investigation of the client's activities. ${ }^{307}$

568-69 (7th Cir. 1990) (refusing to enforce subpoena to defense counsel where disclosure of identity of client who has paid fees for another client would be tantamount to disclosure of benefactor/ client's reasons for seeking representation in first place); In re Grand Jury Proceedings (Rabin), 896 F.2d 1267, 1279 (11th Cir. 1990) (enforcing subpoena to defense attorneys for fee records relating to representation of clients in police corruption investigation); In re Grand Jury Subpoena (Slotnick), 781 F.2d 238, 252 (2d Cir.) (en banc), cert. denied, 475 U.S. 1108 (1986) (enforcing grand jury subpoena seeking fee records in organized crime investigation); In re Grand Jury Subpoena Duces Tecum (Slargel), 742 F.2d 61, 64-65 (2d Cir. 1984) (enforcing grand jury subpoena seeking fee information).

In New York, defense lawyer Lynne F. Stewart was recently indicted for criminal contempt following her refusal to comply with a grand jury subpoena seeking disclosure of the source and amount of fees paid on behalf of a former client in a drug prosecution. If convicted, Ms. Stewart could be sentenced to four years in prison and would face autonatic disbarment. See Ronald Sullivan, Lawyer Cited for Contempt over Fee Data, N.Y. Times, Apr. 18, 1991, at B1; Daniel Wise, N.Y. Lawyer Indicted for Criminal Contempt, NAT'L L.J., Apr. 29, 1991, at 18; see also In re Grand Jury Subpoena (Stewart), 548 N.Y.S.2d 679 (App. Div. 1989), appeal dismissed as untimely, 556 N.E.2d 1119 (N.Y. 1990).

303. See, e.g., DeGuerin II, 926 F.2d at 1426.

304. See 26 U.S.C. $\$ 6050 \mathrm{I}(1988)$.

305. See 26 C.F.R. § 1.6050I(a) (1991).

306. Specifically, Form 8300 require that the lawyer specify the client's name, address, social security number, taxpayer identification or passport number, the date, amount, method of, and reason for the payment, and the identity of the provider of the services. See id. $\S 1.6050 I-1(e)(2)$. In a recent amendment, a box was added to the form which the attorney is supposed to check if a cash transaction with a client is "suspicious." See Lawyers Must Tell IRS Names of Cash Clients, 4 Crim. Practice Man. (BNA) 299, 299 (June 26, 1991).

The enforceability of Form 8300 was upheld over challenges based in the attorney-client privilege, and the Fourth, Fiftli, and Sixth Amendments in United States v. Goldberger \& Dubin, P.C., 935 F.2d 501 (2d Cir. 1991). The Goldberger \& Dubin court warned lawyers that failure to comply with the forms might support criminal prosecution under federal law. Id. at 506. Cf. Umited States v. Leventlial, No. 91-41-MISC-ORL-18, 1991 U.S. Dist. LEXIS 4172 (M.D. Fla. Mar. 12, 1991) (ordering disclosures under Form 8300 , but taking view that counsel properly resisted disclosure under attorney-client privilege prior to "direction of the court").

307. See 26 C.F.R. $\$ 1.6050 I-1$ (a) (1991). The above categories of evidence and information, obtained through counsel, can be useful to the government and incriminating to the client in a number of ways. Disclosure of the identity of a client may be damaging if the prosecutor knows that an attorney is representing an unidentified person in connection with a specific crime, but lias not been able to discover who committed the crime through other means. See Baltes v. Doe I, No. CL88-1145-AD, 57 U.S.L.W. 2268 (Fla. Cir. Ct. Oct. 13, 1988) (rnling that attorney could be not be compelled by subpoena to revcal identity of client involved in a lit-and-run accident based upon the court's conclusion that client identity and fee information are included within the Florida state law definition of attorney-client privilege). Disclosures of client identity on Form 8300 miglt serve as a 
If any of the above evidence and information were demanded from the chent directly, he would respond with an assertion of his Fifth Amendment passivity rights. In at least some cases, the claim would prevail. For example, the client cannot be required during a crimimal investigation to come forward and identify himself as the perpetrator, or even as a possible perpetrator, of an offense under investigation. ${ }^{308}$ Similarly, the client may well succeed in resisting a subpoena to supply testiinony and physical evidence establishing a financial or other relationship between himself and an alleged co-conspirator. ${ }^{309}$ Apart from whether the chent would prevail in the specific case, it is clear that the question of disclosure would turn upon apphication of the self-incrimination clause.

When a legal command is directed to the lawyer mstead of the client, however, the terms of arguinent become materially different. Under Fisher, counsel may not raise issues surrounding the client's passivity rights unless the attorney-chent privilege is first shown to apply. On this score, the overwhelming inajority of courts have found that the attorneychent privilege does not extend to evidence and inforination relating to chent identity, fee information, and fee-payer information. ${ }^{310}$ As a result, nearly every court passing upon the propriety of such legal coininands has held that defense lawyers must provide the requested evidence

red flag to the government to initiate an investigation of that person, based upon the fact that he las paid a substantial amount of inoney to retain the services of a criminal lawyer. Information concerning fee arrangeinents inight be sought for a variety of additional purposes. For example, the fact that a chent has paid a large fee to a lawyer could be evidence of "unexplained wealth" and thus relevant to a charge that the client coinmitted a crime involving pecuniary gain. See In re Grand Jury Subpoena Served upon Doe (Slotnick), 781 F.2d 238, 248 (2d Cir. 1985) (en banc), cert. denied, 475 U.S. 1108 (1986). Alternatively, the fact that someone other than the client is paying the client's fees inay show a conspiratorial or other relationship between the client and fee-payer that the governinent wishes to establish as part of a criminal charge. See In re Grand Jury Subpoena (DeGeurin II), 926 F.2d 1423, 1432 (5th Cir. 1991). Such benefactor payments niay also be relevant to proof of an ongoing criminal agreeinent that the fee-payer will "take care" of the client's legal bills during criminal proceedings in exchange for past or present illegal services. See In re Grand Jury Proceedings (Pavlick), 680 F.2d 1026, 1029 (5th Cir. 1982).

308. Cf. Baltes, 57 U.S.L.W. at 2268 (holding that attorney cannot be conpelled to reveal identity of a client involved in a hit-and-run accident).

309. See Malloy v. Hogan, 378 U.S. 1, 12-14 (1964); supra note 19. With respeet to the con1pelled production of record evidence, sec supra Part III(A)(2).

310. The reasoning of such decisions is that coinnunications to a lawyer concerning these subjects are not inade for the purpose of obtaining legal assistance. See In re Shargel, 742 F.2d 61, 63 (2d Cir. 1984). Instead, the courts sec such communications as limited to interpersonal and business necessities unrelated to a lawyer's need to learn the facts of the case. See In re Grand Jury Subpoena Served upon Doe (Slotnick), 781 F.2d 238, 247-48 (2d Cir. 1985) (en banc), cert. denied, 475 U.S. 1108 (1986). With respect to benefactor payments, the privilege is considered unavailable for the additional reason that fee-related communications lave not occurred between privileged persons, at least when the fee-payer is not himself a client of the lawyer. See In re Grand Jury Subpoena (DeGeurin I), 913 F.2d 1118, 1123 (5th Cir. 1990); In re Grand Jury Subpoena (Anderson), 906 F.2d 1485, 1491 (10tl Cir. 1990). 
and testinony, and that potential incrimination of the client is not a relevant concern. 311

Although the attorney-subpoena cases have inost often involved client identity and fee information, they have not been restricted to such investigative ends. For example, In re Grand Jury (Attorney $X)^{312}$ involved a grand jury subpoena that sought defense counsel's testimony concerning whether and what he had told his chent about a specific federal investigation into organized crine activity. The governinent intended to charge the client with obstruction of justice durmg that investigation, and wanted the lawyer's testimony to help ineet its burden of proof as to the chent's knowledge of the pending investigation when the alleged acts of obstruction occurred. ${ }^{313}$ The court found that the attorney-chent privilege did not bar comphance with the subpoena by Attorney $\mathrm{X}$ because the lawyer had acted as a "inere conduit" for mformation concerning the organized crime investigation, which he had learned froin a third party and relayed to his client. ${ }^{314}$ The court ruled that the question of whether counsel's testinony might incriminate the client was immaterial to its determination of whether the attorney-client privilege apphied. ${ }^{315}$ Thus, as with the chent-identity and fee-information cases, the chent's passivity rights were never brought in issue. Instead, the revelation of chent-incriminating testinony by the lawyer-going directly to a required element of the governinent's obstruction case against the chent-was contingent upon the court's interpretation of a common

311. In the early days of the attorney-subpoena cases, at least one court of appeals flirted with the idea that the availability of the attorney-cheut privilege might turn upou the chent-incriminating nature of the evidence or testimony sought from the lawyer. See In re Grand Jury Proceedings (Pavhick), 680 F.2d 1026, 1027 (5th Cir. 1982); In re Grand Jury Proceedings (Jones), 517 F.2d 666, 672, 674 (5th Cir. 1975). The court in Pavlick coined the widely used term, the "last link" doctrine, to capture its holding that generally unprivileged information may still receive attorney-chent protection when it is sufficiently incriminating to the chent: "[Jones recognized] a limited and narrow exception to the general rule, one that obtains when the disclosure of the chent's ideutity by his attorney would have supplied the last link in an existing chain of incriminating evidence likely to lead to the client's indictment." Pavlick, 680 F.2d at 1027 (emphasis added). Later decisions, however, have resoundingly rejected Jones' "mcrimmation rationale" as a basis for the attorney-client privilege. See, e.g., In re Grand Jury Subpoena (DeGuerim II), 926 F.2d 1423, I431 (5th Cir.) ("We protect the client's identity and fee arrangements . . . not because they might be incriminating but because they are connected inextricably with a privileged communication-the confidential purpose for which he sought legal advice."), cert. denied, 111 S. Ct. 1581 (1991); In re Grand Jury Matter (Doe I), 926 F.2d 348, 352 (4th Cir. 1991) ("[T] he mere fact that the [fee] arrangemeuts evidence wrongdoing by the client does not implicate the attorney-client privilege.") (quotation omitted); see also DeGeurin I, 913 F.2d at 1124-25; Anderson, 906 F.2d at 1489-92 (rejecting incriminatiou rationale of the so-called "last huk exception" from Pavlick, Jones, and Baird).

312. 621 F. Supp. 590 (E.D.N.Y. 1985).

313. Id. at $591,594$.

314. Id. at 592 .

315. Id. (citing In re Shargel, 742 F.2d 61, 63 (2d Cir. 1984)). 
law privilege whose requirements are unresponsive to Fifth Amendment concerns. ${ }^{316}$

In other cases, the government has been successful in compelling defense counsel to reveal evidence or information concerning the address or whereabouts of a fugitive chent. In Commonwealth v. Maguigan, ${ }^{317}$ the chent failed to appear for trial on charges of rape, statutory rape, and other offenses. The trial court ordered Holly Maguigan, defense counsel, to divulge "any information she may have" going to her client's present whereabouts or how he might be located. ${ }^{318}$ The state Superior Court concluded that this order would convert defense counsel "into an investigative arm of the prosecution" because there were no discernable limits upon the confidential information that "inay" lead to discovery of the chent's location. ${ }^{319}$ The state Supreme Court, however, ruled that the order would be enforced. ${ }^{320}$ The Maguigan courts, like others discussed here, did not consider the question of whether the chient's passivity rights would be miplicated by the compelled testimiony of counsel. ${ }^{321}$

The pattern of hitigation in the above cases is strikingly different froin attorney-subpoena cases of the Fisher variety. Under Fisher, Fifth Amendinent concerns were forefront to the case and its outcoine. However, where the formal prerequisites of the attorney-chent privilege cannot be satisfied, creative prosecutors have found success in plumbing

316. In Pennsylvania, defense attorney Linda Backiel was inprisoned for six inonths for her refusal to produce evidence and give testimony regarding the inotives and intentions of a client who had junped bail. Purportedly, Backiel was in possession of a docuinent authored by the client setting out her reasons for flight; the government also believed that Backiel could authenticate an alleged copy of the same document already in the government's possession. Thus the governinent did not seek evidence inerely of the client's whereabouts, but sought evidence going to its eventual proof of a bail-jumping charge against the chient. See Lawyer Is Freed After Being Jailed Six Months for Refusing to Testify, N.Y. TIMEs, Jime 11, 1991, at A17; LeDuc, supra note 5, at 2; Defense Lawyer Is Jailed over Client Confidentiality, N.Y. TimEs, Feb. 15, 1991, at A16; see also In re Backiel, 906 F.2d 78, 87-88 (3d Cir. 1990).

317. 511 A.2d 1327 (Pa. 1986).

318. See Maguigan, 511 A.2d at 1331.

319. Commonwealth v. Maguigan, 470 A.2d 611, 618 ( $\mathrm{Pa}$. Super. Ct.), rev'd, 511 A.2d 1327 (Pa. 1986); see also Maguigan, 511 A.2d at $1338 \mathrm{nn} .13-14$.

320. The court held that such information was unprotected by the attorney-client privilege on the theory that the client's failure to appear was a continuing offense, that the client hinself had no lawful right to withhold information concerning his whereabouts from the court, and that therefore his attorney could not make an effective assertion of privilege. See Maguigan, 511 A.2d at 1334-36.

321. In addition to Maguigan, see In re Grand Jury Subpoenas Served upon Field, $408 \mathrm{~F}$. Supp. 1169, 1174 (S.D.N.Y. 1976) (ruling that attorneys may be questioned as to their clients' whcreabouts); In re Nackson, 555 A.2d 1101, 1106-07 (N.J. 1989) (holding that information concerning whereabouts of fugitive client falls within attorney-client privilege, but government may still compel attorney to disclose such imformation if it demonstrates that other attempts to obtain the information prove futile and the public interest in obtaining the information outweighs the client's legitimate expectations of confidentiality). 
defense counsel as sources of client-incriminating evidence and information, bypassing the Fifth Amendinent concerns that would arise if equivalent investigative commands were addressed to the client personally.

Such end-runs will prove fruitful only where soine other privilege or limitation does not shield the information at issue. Other than the attorney-chent privilege, the principal protections in current application are the work product doctrine and the rules of professional conduct that proscribe prosecutors' use of defense lawyers as witnesses during a crimmal investigation. Before concluding that present safeguards are madequate to effectuate criminal suspects' constitutional passivity rights, a brief exploration of the work product rule and of applicable conduct rules is necessary.

The work product doctrine lias no apphication to most of the problems considered in this Article. It is designed to safeguard materials generated in preparation for hitigation. ${ }^{322}$ Where it does apply, it has severe limitations. First, it lias hittle or no application to preexistimg physical evidence obtained by the lawyer during her investigation. ${ }^{323}$ Second, its protections are lardly coequal with the Fiftl Amendment privilege, since the work product rule is inerely a "qualified" protection, ${ }^{324}$ which can be overridden by a government showing of "need" or "good cause." 325 Third, as with the attorney-chent privilege, the courts

322. This is not an exhaustive statement of the coverage of the work product doctrine, which would be difficult to make because the boundaries of the doctrine are far from clear. See Special Project, The Work Product Doctrine, 68 CORNELL L. REV. 760, 762-63 (1983) (reporting continuing debate concerning the scope of the doctrine). The doctrine originated in the famous case of Hickman v. Taylor, 329 U.S. 495 (1947), and applies in both civil and criminal cases. See United States v. Nobles, 422 U.S. 225 (1975). The Nobles Court said that "[a]lthough the work-product doctrine most frequently is asserted as a bar to discovery in civil hitigation, its role in assuring the proper functioning of the criminal justice system is even more vital." Id. at 238; see also Upjohn v. Umited States, 449 U.S. 383, 386, 397-402 (1981) (applying work product doctrine to proceedings to enforce IRS summonses investigating possibly illegal payınents by American companies to foreign government officials). Federal Rule of Criminal Procedure 16(b)(2) makes the work product rule expressly apphicable to pretrial discovery in federal criminal cases. Like the attorney-client privilege, the work product doctrine is separately formulated in eacli jurisdiction. See generally 4 JAMES W. MOORE ET AL., Federal PRactice $\S \S 26.63-64$ (1991); 8 Charles A. WRight \& ARThuR R. MiLleR, Federal Practice \& Procedure $§ \S 2021-28$ (1970); Special Project, supra, at 873-76. See also RESTATEMENT OF THE LAW Governing LAwYERS, $\$ 136$ (Tent. Draft No. 2, 1989) (discussion draft only for $\$ 136$ ).

323. By "prcexisting" evidence, I mcan evidence that is obtained by defense counsel or a defense investigator rather than evidence generated by the defense team.

324. Some hold that the work product rule is not a true privilege at all, but merely a limitation upon discovery. See Nobles, 422 U.S. at 243 (White, J., coneurring).

325. It is generally recognized that so-called "opinion" work product-that which would reveal a lawyer's strategic thought processes-is deserving of the greatest degree of legal proteetion available under the doctrine. Accordingly, the courts have set high standards of good cause required to 
have created other exceptions to the work product protection, including crime-fraud and waiver. ${ }^{326}$

This is not intended as a critique of the work product rule. Instead, it is meant to show that the doctrine is imperfectly adapted as a surrogate protection for the passivity rights held by individual criminal suspects. It is simply designed to protect different interests. To the extent that the work product rule by happenstance provides a safeguard for some few items of client-incriminatimg evidence, it is a qualified and uncertain shield, subject to sucli exceptions as "showing of need" or "waiver." Qualifications of this kind either do not exist under the Fifth Amendment, or exist in substantially narrower form.

Another way to limit the government's use of defense counsel as a source of chient-incriminating evidence is through rules of professional conduct that make it a professional violation for a prosecutor to direct a subpoena or similar legal command to a defense lawyer without prior judicial approval. In 1990, the ABA adopted a provision of this kind in Rule 3.8(f) of the Model Rules of Professional Conduct:

The prosecutor in a criminal case shall:

(f) not subpoena a lawyer in a grand jury or other criminal proceeding to present evidence about a past or present client unless:

(1) the prosecutor reasonably beheves:

(i) the information sought is not protected froin disclosure by any applicable privilege;

(ii) the evidence sought is essential to the successful coinpletion of an ongoing investigation or prosecution;

(iii) there is no other feasible alternative to obtain the inforination; and

overcome the qualified privilege for such materials, making it difficult or impossible to obtain production. In contrast, ordinary or non-opinion work product-that which is comprised merely of factual evidence or information-may be producible upon a less rigorous showing of need. See Upjohn, 449 U.S. at 399; In re Martin Marietta Corp., 856 F.2d 619, 626 (4th Cir. 1988), cert. denied, 490 U.S. 1011 (1989); In re John Doe Corp., 675 F.2d 482, 492-93 (2d Cir. 1982).

326. The courts have held that materials prepared by lawyers in anticipation of litigation will not be shielded from production where the government makes a prima facie or probable cause showing that the materials were used as part of an ongoing criminal scheme. For example, in $I n$ re John Doe Corp., 675 F.2d 482 (2d Cir. 1982), the Second Circuit held that work product protection was unavailable for an internal investigative report of a business prepared by counsel. The court concluded that there was probable cause to believe that the report was part of an ongoing criminal schene to conceal prior bribe payments and other misconduct by agents of the corporation. See id. at 491; see also In re Special September 1978 Grand Jury (II), 640 F.2d 49, 63 (7th Cir. 1980).

Recent waiver cases have caused some to comment that the protection has been badly eroded. See Willcox, supra note 5. Mr. Willcox, who is Umited States Attorney for the District of Maryland, made the following comment about the recent Fourth Circuit decision in Martin Marietta: "By expanding the potential for waiver of the protection afforded by the two doctrines [the attorneychent privilege and work product doctrinel, the court has opened most, if not all, of a lawyer's litigation file to hostile parties under many circumstances." Id. at 917. 
(2) the prosecutor obtains prior judicial approval after an opportunity for an adversarial proceeding. ${ }^{327}$

No state has yet adopted Model Rule 3.8(f) but, prior to its drafting, a handful of states and one federal district court had adopted substantially similar provisions. ${ }^{328}$ Even where enacted, the enforceability of these rules in federal criminal proceedings has been highly controversial. ${ }^{329}$ In the absence of an express rule, federal courts of appeals that have addressed the question have concluded that federal prosecutors are not required to inake a preliminary showing before issuing grand jury subpoenas to defense counsel. ${ }^{330}$

Whatever the merits of Model Rule 3.8(f) and similar provisions, they are not designed to inject new concerns for chent passivity rights into the attorney-subpoena context. Subpart (f)(1)(i) requires a reasonable behief on the part of a prosecutor that the legal command to defense counsel will not offend "any apphicable privilege." Thus the rule incorporates the law of privileges external to the conduct codes, leaving unchanged and unaddressed the scope of the privileges defense counsel inay assert when served with a subpoena. ${ }^{331}$

Any other approach would have been highly atypical for the drafters of the Model Rules and the Model Code. The conduct codes have

327. Model Rules of Professional Conduct Rule 3.8(f) (1990).

328. Effective January 1, 1986, the Supreme Judicial Court of Massachusetts adopted a conduct rule designated Prosecutorial Function 15, or "PF 15," which provides as follows: "It is unprofessional conduct for a prosecutor to subpoena an attorney to a grand jury without prior judicial approval in circumstances where the prosecutor seeks to compel the attorney/witness to provide evidence concerning a person who is represented by the attorney/witness." Thereafter, the district court for the District of Massachusetts amended its local mles to include PF 15, effective July 1 , 1986. See United States v. Klubock, 832 F.2d 649, 650 (1st Cir.), aff'd, 832 F.2d 664 (1st Cir. 1987) (en banc). The Supreme Courts of Tennessee, Virginia, Pennsylvania, and Rhode Island have adopted similar conduct rules. See PA. Rules of CourT, State Rules of Professional Conduct, Rule 3.10 (1991); R.I. CourT Rules, Supreme Court Rule 47, Rule of Professional Conduct 3.8(f) (1991); TENN. Rules of CourT, State Rule 8 DR 7-103(c) (1987); VA. Rules, Rule DR 8-102(A) (1987); VA. SUPREME COURT Rules, Rule 3A:12 (1990).

329. See Klubock, 832 F.2d at 649. This is the only federal court to uphold application of rule similar to Model Rule 3.8(f) in federal criminal proceedings. See also Baylson v. Disciplinary Bd. of Supreme Court of Pa., 764 F. Supp. 328 (E.D. Pa. 1991) (holding that district courts have no power to place restrictions upon grand jury proceedings through adoption of such a rule).

330. See, e.g., In re Grand Jury Matter (Doe I), 926 F.2d 348, 350 (4th Cir. 1991); In re Grand Jury Subpoena (DeGuerin I), 913 F.2d 1118, 1127,1129 (5th Cir. 1990); In re Grand Jury Subpoena (Anderson), 906 F.2d 1485, 1495-96 (10th Cir. 1990); In re Grand Jury Subpoena Served upon Doe (Slotnick), 781 F.2d 238, 248 (2d Cir. 1985) (en banc), cert. denied, 475 U.S. 1108 (1986).

331. The official comment to Rule 3.10, PA. Rules of COURT, State Rules of Professional Conduct, is a noteworthy exception. It provides:

It is intended that the required "prior judicial approval" will normally be withheld unless, after a hearing conducted with due regard for the need for appropriate secrecy, the court finds (1) the information sought is not protected from disclosure by Rule 1.6, the attorney-client privilege or the work product doctrine; (2) the evidence sought is relevant 
delineated so-called "ethical" duties of confidentiality, ${ }^{332}$ but such duties fall aside when an attorney is placed under an enforceable legal command to come forward with otherwise confidential evidence or information. ${ }^{333}$ The conduct codes have never purported to create new privileges sufficient to defeat disclosure obhigations imposed by law. ${ }^{334}$

The mechanism envisioned by Model Rule 3.8(f) may mdirectly protect chent passivity rights simply by making it harder for the government to serve subpoenas upon defense counsel. The rule requires that prosecutors, and perhaps courts in approving subpoenas, ${ }^{335}$ must be satisfied that a degree of necessity exists to subpoena defense counsel, roughly analogous to the showing of need required under the work product doctrime. ${ }^{336}$ Thus, even if Rule 3.8(f) were to be adapted widely, its shield is necessarily an uncertain one that will fluctuate with case-by-case assessments of the exigency of the government's request. In this respect, it cannot be coextensive with the passivity rights held by the criminal suspect, which do not yield to clanns that the communications sought are urgently required.

\section{Summary of Parts II and III}

The broad theme of Parts II and III has been the study of circun1stances in which criminal defense lawyers presently are conipelled by law or rule of professional conduct to produce chent-mcriminatimg evidence, as considered aganist the backdrop of the chent's Fifth Amendment passivity rights. Under the Olwell cases, counsel may be required to come forward even though there has been no governmental request or specific

to the proceeding; (3) compliance with the subpoena would not be unreasonable or oppressive; (4) the purpose of the subpoena is not primarily to harass the attorney/witness or his

or her chent; and (5) there is no other feasible alternative to obtain the information sought.

Id. The district court in Baylson said that, if this comment were credited, it would elevate the conduct rule of confidentiality into an evidentiary privilege. This was one basis for the court's conclusion that Rule 3.10 would not be enforced in the federal district courts of Pennsylvania. See Baylson, 764 F. Supp. at 344-45.

332. See Model Rules of Professional Conduct Rule 1.6 (1988); Model Code of ProFESSIONAL RESPONSIBILITY DR 4-101 (1980).

333. See supra Part II(B).

334. Rule 3.8(f) and its precursors have drawn criticisun on the ground that they are not properly cast as rules of professional conduct for lawyers, but are attempted modifications of the rules of procedure for criminal mvestigations and the substantive law of privileges. See, e.g., United States v. Klubock, 832 F.2d 649, 670-71 (1st Cir.) (Campbell, C.J., dissenting), aff'd, 832 F.2d 664 (1st Cir. 1987 ) (en banc); Baylson, 764 F. Supp. at 337; Robert G. Morvillo, When an Attorney Is Subpoenaed, N.Y. L.J., June 4, 1991, at 3, 6.

335. Rule 3.8(f)(2) does not set out formal requirements to be applied by judges in determining whether to approve the issuance of a subpoena, but the rule appears to contemplate that the courts will inquire into whether the factors enumerated in Rule 3.8(f)(1) are satisfied.

336. See Model Rules of Professional Conduct Rule 3.8(f)(1)(ii), (iii) (1990). 
legal command to do so. When the courts pass upon the scope of the Olwell obligation, they rarely ask whether the client could personally be required to turn over the same evidence. The Olwell court itself treated the defense attorney little differently than a disinterested third party, with no standing to raise his client's passivity rights, and other decisions in the Olwell line have largely followed suit. Thus, Olwell had an obligation to come forward with the knife in his possession irrespective of whether his client could lave been compelled to do so. In Morrell, the public defender had the duty to disclose the kidnap plan whether or not Morrell himself could have been required to do so. The chient's Fifth Amendment rights, in such cases, are beside the point.

The law has developed in a different and inore complex fashion when defense lawyers are placed under specific legal command to disclose client-incriminating evidence. In contrast to the Olwell decisions, the chent's passivity rights are sometimes given play in legal command cases, but there are still many circumstances in which those rights are ignored. The Supreme Court's Fisher decision, if adopted by the states, invalidates inuch of the Olwell rule in declaring that the client's passivity rights must be considered when the government seeks to obtain evidence froin counsel obtamed in connection with a protected attorney-chent communication. Outside of such circumstances, however, the legal coinmand cases adhere to the spirit of Olwell in declaring that compelled production froin a defense lawyer does not implicate the chent's Fifth Amendment rights. Thus, in a growing number of situations, the courts have permitted prosecutors to elicit evidence and testimony froin counsel without considering the question of whether an equivalent legal command could be enforced agamst the chient.

When this is allowed to happen, the chient's Fifth Amendment passivity rights are effectively diminished. The chent's ability to conduct a defense while withholding active cooperation from the government has been reduced, but the scope of the self-incrimination privilege is never litigated. Now, it inay well be that in some or inany Olwell cases the courts would find that the suspect's passivity rights do not bar compelled production, from suspect or lawyer. ${ }^{337}$ The same may be true in much of the legal command hitigation. ${ }^{338}$ The proper reach of the self-incrinination clause in individual cases is subject to differing judgments, and the law will continue to develop as particular cases come before the

337. Injection of Fifth Amendment concerns would not produce automatic defense victories. See infra notes 347-50 and accompanying text.

338. Fisher was a case of this type, in which the clients' self-incrimination claims were considered, but ultimately found lacking, by the Court. See supra Part III(A)(2). 
courts. ${ }^{339}$ Whatever the state of Fifth Amendment law, however, there should be a level playing field for defendants who entrust the defense of their case to a lawyer. We should not tolerate a system that grants rights of passivity to criminal suspects in the abstract, but holds that those rights will be effectively diluted for the great majority of suspects who must and do obtain counsel to prepare and to present their case. This is the subject taken up in Part IV.

\section{The Need for a Projected Fifth Amendment Privilege}

In an ideal world, the constitutional rights given to a suspect in a criminal case would exist unchanged, whether or not he obtains counsel. Of course, his practical ability to understand and claim his rights will normally improve with a lawyer's assistance. However, the abstract contours of the suspect's rights should not shift merely because he requires an attorney to gain access to them. ${ }^{340}$ There should be no constitutional tariff upon the act of obtaining counsel.

Under the law surveyed in this Article, there are two interrelated asymmetries between the theoretical legal abilities of an unrepresented suspect to conduct a defense consistent with constitutional guarantees, on the one hand, and the comparable abilities of a suspect represented by counsel on the other. First, a lawyer caunot claim the Fifth Amendment rights of passivity that the self-representing chent would enjoy if competent to conduct his own defense. Second, but cutting in the opposite direction, the privileged status of the law office gives the lawyer powers of immunity from investigation that the unrepresented client would not have on his own. This second problem is illustrated by the "depository" concern voiced in the Olwell cases, ${ }^{341}$ and by the concern in the attorneysubpoena cases that lawyers may shield or participate in the ongoing criminality of their chents. The second problem is largely responsible for the first. Because we are suspicious of lawyers' abilities to conceal evidence of crimes behind a veil of confidentiality, we have developed makeshift devices to pierce the veil.

In the following pages, I suggest new approaches to these twin problems consistent with the view that a suspect's rights should not change when a lawyer enters the case. First, I propose creation of a

339. For example, future developments in the law of immunity under the act of production doctrine could substantially narrow the force of Fifth Amendment protections surrounding the compelled production of physical evidence. See supra Part $1 \mathrm{II}(\mathrm{A})(3)$.

340. See Stephen A. Saltzburg, Lawyers, Clients, and the Adversary System, 37 MERCER L. REv. 647,662 (1986).

341. See supra notes $139-42$ and accompanying text. 
"projected" Fifth Amendment privilege to equalize the operation of passivity rights for represented and unrepresented suspects. Second, I suggest that a new investigative procedure, a "hybrid order," should be developed to remove the special insulation of the law office froin search and seizure, and to address the depository problem inore directly and effectively than it has previously been addressed.

\section{A. Statement of the Projected Privilege}

The inost effective way to ensure that a client's Fiftl Amendment passivity rights are not impaired when lie obtains a lawyer is to recognize a "projected privilege" that would allow counsel to assert the client's Fiftl Amendment privilege wlien compelled to provide client-incriminating evidence to the government. ${ }^{342}$ The terms of the projected privilege miglit be delineated as follows:

A lawyer should be permitted to assert her chient's privilege against self-incrimination with respect to all evidence and information that might miplicate the chient in past crimes when such evidence and information was lawfully acquired by the lawyer in the scope of the representation..$^{343}$

The projected privilege should be adopted as a matter of constitutional law under the Fifth and Sixtlı Amendments, the Due Process Clause of the Fourteenth Amendment, and under analogous provisions of the various state constitutions. ${ }^{344}$ Regardless of whetler the privilege attains constitutional status, lowever, it sliould also be adopted as a matter of the statutory or common law of privileges within each jurisdiction, and sliould be reflected within apphicable canons of professional conduct.

The driving principle behind the projected privilege is the preservation of the status quo defined by the client's abstract passivity rights in the absence of a lawyer. The projected privilege would be available to the attorney in all circumstances where the client could claim a lawful ability under the Fifth Amendment to resist disclosure of evidence. In

342. The image of a "projected privilege" was suggested by my research assistant, Elizabeth Griffin.

343. This expands upon Fisher's simulated Fifth Amendment privilege, which extends only to evidence received by the lawyer in connection with a communication protected by the attorney-client privilege. See supra Part III(A)(1). In contrast, the proposal here would reach all evidence and information acquired during the representation, as long as it was lawfully acquired by the lawyer.

Stern and Hoffman have proposed a "non-mcrinination" privilege that bears some resemblance to the projected privilege, but would not apply to physical evidence, including docunsents. The authors would retain the Olwell rule requiring the lawyer to come forward with such evidence. See Stern \& Hoffnian, supra note 5, at 1835-43.

344. The Fifth Amendnient contains the passivity rights that would define the scope of the projected privilege. The Sixth and Fourteenth Amendments speak to the state's obligation to see that a suspect's right to obtain effective assistance of counsel in a criminal case is not impaired. 
effect, defense counsel would be regarded as the client's counterpart in the course of the representation, and would be permitted to conduct the defense as the law would allow a self-representing client to do.

So conceived, the underlying Fiftlı Amendinent rights asserted by the lawyer are tliose belonging to the chent. The client's passivity riglits would be "projected" onto her attorney to govern an interaction between the government and the attorney. In addition, the lawyer would be allowed to claim the privilege, unless waived by the client, rather than requiring the chient to object personally. ${ }^{345}$ In both respects, the projected privilege would operate in a way similar to the attorney-chent privilege under present law. ${ }^{346}$

The projected privilege would be available whetler or not the lawyer lias been served with a specific legal command to produce evidence. Thus it would speak to situations arising under the Olwell line of decisions discussed supra in Part II, as well as the legal coininand cases in Part III. In all such circunstances, the chent's passivity riglits would control.

The privilege would extend to both client-source and nonclientsource evidence. In a case like Morrell, the relevant question in determining the application of the privilege would be whether the client would have liad any legal obligation to disclose the kidnap plan if lie hinself had received it from a third party or otlerwise had had it in his possession. Viewing the lawyer as the client's counterpart, counsel's position upon taking the plan from a third party should be the sane as the client's, if the chient had undertaken to prepare his own defense instead of entrusting this task to his lawyer.

The projected privilege does not provide that all obligations on the part of defense lawyers to produce evidence must be abolished. Cases of mandated disclosure under Olwell or by legal coininand would not be summarily reversed, and many might be uplield. The privilege is designed simply to mject Fifth Amendment issues into consideration when defense lawyers are obliged to come forward and supply active cooperation to the government. The proper scope of the client's passivity rights would then be contested and, as in Fisher, inay not ultinately bar

345. This second facet of the projected privilege should not be controversial. We routinely allow lawyers to communicate their chent's decisions to exercise their Fifth Amendment rights. See, e.g., People v. Myers, 220 N.E.2d 297 (Ill. 1966); State v. McDowell 247 N.W.2d 499 (Iowa 1976); Victoria v. State, 522 S.W.2d 919 (Tex. Crim. App. 1975).

346. The attorney-client privilege is thought to be held by the client, but is normally asserted by counsel. See, e.g., Umited States v. Partin, 601 F.2d 1000, 1009 (9th Cir.), cert. denied, 446 U.S. 964 (1979); Repubhic Gear Co. v. Borg-Warner Corp., 381 F.2d 551, 556 (2d Cir. 1967). 
production. ${ }^{347}$ The outcome of each case is a matter of less importance than the fact that the result will be the same regardless of whether the chent or lawyer has been asked to come forward. ${ }^{348}$

Two important limitations upon the projected privilege spring from its underlying purpose to preserve the constitutional status quo. First, the proposed privilege would not permit an attorney to assist a client im the commission of a new or ongoimg offense under the guise of legal representation. The privilege attaches only to evidence of completed crimes. Conduct that would liave been illegal if performed by an unrepresented client remaims illegal when performed by counsel or with counsel's assistance. Evidence or information acquired by a lawyer in the course of such unlawful activity garners no protection because, as defined, the projected privilege reaclies only evidence and inforination "lawfully acquired" by counsel. ${ }^{349}$ Thus, an important core of the Olwell rule would be retained: In those few occasions where the lawyer's conduct im handling evidence rises to the level of an obstruction or contraband offense, the privilege would offer no shield. ${ }^{350}$

347. Consideration of the privilege would not change the result in cases like In re Ryder, $263 \mathrm{~F}$. Supp. 360 (E.D. Va.), aff'd, 381 F.2d 713 (4th Cir. 1967), where applicable law nnakes it a continuing crime for the suspect or the lawyer to retain possession of the relevant evidence. The self-incrimination clause does not provide license to engage in or continue a criminal activity. See supra Part II(B)(2). Nor would the Fifth Amendinent overwrite the concerns of the court in People v. Meredith, 631 P.2d 46 (Cal. 1981), where the removal of evidence froin the crime scene could be analyzed as the "destruction" of contextual facts necessary to inake the evidence meaningful to the government. Under the obstruction laws, it might be found that this is an affirmative act of concealment that renders the attorney's conduct criminal-just as the same conduct by the client would be a criminal offense. See supra Parts $\mathrm{II}(\mathrm{A})(3) \& \mathrm{II}(\mathrm{B})(1)$.

348. In the context of Form 8300 cases or cases where the government seeks disclosure from an attorney regarding fee information, the defense may well be ordered to disclose even under the projected privilege. As a general inatter, the Fifth Amendment does not shield people from coinpelled reporting of monetary transactions between themselves and another person. If this describes the self-incrimination privilege as held by the suspect, the protection would not expand because of introduction of the projected privilege. Counsel, no less than the client, could be conpelled to reveal unprivileged transactions.

Also, in a case such as Commonwealth v. Maguigan, 511 A.2d 1327 (Pa. 1986), discussed supra in Part III(C)(1), the government might still prevail under the projected privilege. The Pennsylvania Supreme Court took the view that the fugitive client had no legal right to withhold information concerning his whereabouts from the government. See id. at 1334-36. Assuming this is correct as a matter of Fifth Amendinent law (the Maguigan court did not address the point), the lawyer would have no greater ability than the client to withhold the requested information under the projected privilege.

349. This aspect of the projected privilege incorporates the crime-fraud exception of the attorney-client privilege. See supra notes 263 \& 298 and accompanying text.

350. This provides rooin for the developinent of state law, consistent with Fifth Ainendment limitations, concerning obstruction and contraband offenses. For example, a state persuaded by the reasoning of Meredith inight hold that removal of evidence from the scene of a crime, or soine other ineaningful place, comprises the "destruction" of intangible, contextual evidence falling within the 
Second, the projected privilege is not designed to supplement the client's abstract legal riglits during a criminal investigation by creating new or greater obstacles to law enforcement than those that would exist in counsel's absence. The privilege slould further only the status quo rationale that underlies it; its imtended effect is to preserve, not to enlarge, the client's passivity rights. On one hand, evidence in a lawyer's possession sliould be no more available to the government than when the client lias it. On the other hand, it sliould be no less available. The depository concern, crudely addressed by the Olwell rule, remains a problein whether or not the projected privilege is instituted. We have need of a mechanism to retrieve evidence in a law office comparable to the government's searcli and seizure powers elsewhere. In Part IV(B) below, I suggest the creation of a new procedure, which I call the "hybrid order," to accoinplisli this goal.

\section{B. The Solution to the Depository Problem: The "Hybrid Order"}

1. Mechanics. One apparent defect with the projected Fifth Amendinent privilege is its tendency to exacerbate the "depository" problem discussed supra in Part II(C). The projected privilege threatens to add to the client's legal abilities to witlliold plyysical evidence from the government by permitting evidence to be transferred to the protected environment of the law office. Indeed, there may be temptation for the lawyer to collect evidence so that it inay be shielded in her hands.

Before sketching a tentative solution to the depository problem, an observation is in order. Certainly we should fear the conduct of lawyers who hide important evidence. If we are sensible, however, we must also fear the possibility that evidence will be lost or destroyed if the attorney declines to take possession. This converse danger is especially acute if the evidence is offered to the lawyer by a guilty client, a confederate, or simply a loyal associate. It also exists in cases where the attorney leaves evidence in a place of public access, subject to removal, damage, or destruction. ${ }^{351}$ When we think about the legal rules we ought to have for the incriminating evidence problem, we should not discount the fact that materials in the hands of ethical counsel are relatively certain to remain intact, while there is no similar assurance for materials that remain at large or with criminal actors.

ambit of state obstruction laws. See supra Part 11(A)(3) (discussing Meredith). Such an interpretation of an obstruction statute would extend equally to client and lawyer.

351. In People v. Meredith, 631 P.2d 46 (Cal. 1981), for example, the victim's burnt wallet would have remained in a trash can behind Scott's residence if the defense investigator had not taken possession. It is likely that a trash collector would eventually have taken it away and out of the case forever. See supra Part II(A)(3). 
In addition, the barriers to government access to evidence in a lawyer's possession need not be insurmountable. Indeed, it is possible to envision a new investigative procedure that would allow the authorities to obtain evidence in the law office under circumstances similar to those that would enable them to search for and seize the saine articles in the hands of the client or other private parties. To effect such a goal, I propose the creation of a new "hybrid" court order that shares characteristics of both a subpoena duces tecum and a search warrant. ${ }^{352}$ Such a hybrid order would be designed solely for service upon counsel. It would issue upon sworn application to a neutral judicial officer, when the government can demonstrate probable cause to beheve that the lawyer has possession of evidence of crime that can be described with reasonable particularity. These requireinents are comparable to those in search warrant cases. ${ }^{353}$ To obtain the hybrid order, however, I suggest that the government not be required to make a showing of probable cause that the evidence is im a particular place, but only that it is presently in counsel's possession. In this respect, the hybrid order would be easier to obtain than a search warrant. ${ }^{354}$ The reason for a loose requirement of particularity as to place is that it is both impracticable and undesirable to require the police to surveil lawyers or law offices to determine the exact location of physical evidence once probable cause exists that the evidence is in the lawyer's custody.

352. The hybrid order that I suggest here bears some resemblance to the "proposed discovery rule" offered by Professor Edward A. Tomlinson in Constitutional Limitations on Prosecutorial Discovery, 23 SAN Diego L. REv. 993, 1061-65 (1986). One substantial difference between Professor Tomlinson's approach and my own is that he would "prohibit the prosecution from disclosing to the jury or otler fact-finder the source of the evidence produced," $i d$. at 1062, and would otherwise extend the protections of act of production immunity to the disclosure of evidence, id. at 1063. If sucl immunity is to be extended to tlie suspect, I see no reason to require the government to make a showing of probable cause, or satisfy other Fourth Amendnent requirenents, before ordering the production of evidence. Indced, the Doe $I$ case clearly conteniplates production by suspects under grant of inmunity with no further requirements to be met by the prosecutor. See supra Part III(A)(3). On the other hand, once Fourth Amendment criteria are satisfied, I see no reason to extend all or any part of the act of production immunity to the suspect.

353. See U.S. CoNST. amend. IV; Maryland v. Garrison, 480 U.S. 79, $86-88$ (1987) (requiring particularity as to place); Illinois v. Gates, 462 U.S. 213, 225-30 (1983) (outlining probable cause requirement); Coohdge v. New Hampshire, 403 U.S. 443, 453 (1971) (requiring neutral and detached nuagistrate); Go-Bart Inıporting Co. v. United States, 282 U.S. 344, 349 (1931) (requiring particularity as to things to be seized).

354. See Garrison, 480 U.S. at 84; Stecle v. United States, 267 U.S. 498, 501 (1925). As with otlier Fourth Amendmient requirenients, the requirenient of particularity as to place is one of "reasonable" particularity. Its purpose is to prevent police intrusions into private prenises otlier than those where the evidence sought is rcasonably likely to be found. Because tlie constructive search under the lyybrid order entails no actual intrusion into private space, the reasonableness requirement might be interpreted to allow a hybrid order designed to reach all preinises under the lawyer's control. 
The effect of the hybrid order, once issued and served upon the attorney, would be to compel production of the articles described irrespective of any Fifth Amendment objection the chient could have interposed to a subpoena for the same evidence, including objections available under the projected privilege. In the eyes of the law, production would proceed under the rubric of a "constructive search" of premises in the lawyer's control. If evidence obtained through a constructive search is later introduced at trial, the jury should be told simply that it was discovered in the course of a search of the lawyer's office. ${ }^{355}$ Noncomphiance by an attorney served with a hybrid order should be made a separate criminal offense. 356

For an illustration of the hybrid order's operation in conjunction with the projected privilege, consider the facts in Morrell v. State. ${ }^{357}$ Suppose Cline (Morrell's attorney) had kept the kidnap plan after Wagner (Morrell's friend) gave it to him. The government could not subpoena the plan because Cline would interpose his client's Fifth Amendment privilege. ${ }^{358}$ If the pohice interviewed Wagner, however, they would acquire probable cause to believe that a kidnap plan relating to the charged offense was in counsel's possession. Also from Wagner, they would learn enough about the kidnap plan to describe it with reasonable particularity as required by the Fourth Amendment. Based upon this information, the police could obtain a hybrid order from a local magistrate for service upon Cline. To be sure, this would also be enough for a traditional search warrant for Cline's law office. The difficulty with familiar search procedure, however, is that the police would be required to sort through much of the privileged and confidential inaterials in Cline's office, relating to Morrell and Cline's other clients, in order to execute a traditional warrant. The hybrid order permits the same result as an actual search for the kidnap plan, but with significantly less intrusion upon other privileged and confidential matter. Upon receipt of the hybrid order, under the theory of constructive search, Cline would be required to surrender the plan, irrespective of any Fifth Amendment objections he or his chent would be permitted to raise in response to a subpoena.

355. If the projected privilege is in force, the jury might also be instructed that there is nothing improper about the defense lawyer's conduct in retaining the evidence, and that such conduct is in fact legitimate because it guarantees that the evidence will be preserved intact.

356. It is possible that existing obstruction laws in each state would already criminalize the lawyer's noncompliance but, for clarity, the legislature instituting a hybrid order procedure should separately specify a criminal sanction for noncompliance.

357. 575 P.2d 1200 (Alaska 1978); see supra Part II(A)(2).

358. A successful assertion of the projected privilege would depend upon a finding that, under the Fifth Amendment, Morrell hinself could not be compelled to supply the plan. 
To assess the merit of the proposed hybrid order, the relevant measure should be the same "constitutional status quo" that justifies creation of the projected Fifth Amendment privilege. On this scale, the law should strive to preserve the relative constitutional positions of the suspect and authorities as would exist without the presence of a defense lawyer. Thus the hybrid order will be a successful innovation if it allows an attorney to take possession of physical evidence without imtroducing a new and substantial impediment to orderly law enforcement investigation.

Against this measure the hybrid order has visible strengths and weaknesses. One obvious weakness is that it depends upon the ethics of defense counsel for enforcement, whereas execution of a search warrant depends on the ethics of no one. Of course, the truly unethical defense practitioner would have counseled her chent to dispose of damaging evidence long before questions of projected privilege and hybrid orders were ever raised. In general, however, one might expect a high rate of comphance at the bar. Personal morality aside, few lawyers would risk their careers for one chient. Even fewer would risk personal conviction for a chent.

There is also the problem of who interprets the description of evidence contained in the hybrid order. In an actual search, potice or federal officers decide what is covered by the warrant, subject to judicial review. With the constructive search under the hybrid order, however, defense counsel decides, and the interpretive process is hidden from government scrutiny. ${ }^{359}$ Thus an imprecise description in a hybrid order might be met with a claim that the recipient has no evidence that satisfies the order. This problem is aneliorated somewhat, however, by the fact that the description of the articles sought by the order must meet the particularity requirement of the Fourth Amendment. It may also be addressed in part by the fact that the lawyer faces personal criminal exposure for noncomphiance with the order, and so she will have mcentive to give a reasonable reading to its terms.

A final deficiency of the hybrid order is that its procedures eliminate the possibility that law enforcenent agents will discover the unexpected

359. This is a familiar problem in the subpoena compliance setting. See MaNN, supra note 151:

Probably the most common situation in which the respondent can adopt a legal position without communicating that fact to his adversary is when the government issues a subpoena or summons for records. Here marginal positions often go undisclosed because the client and the defense attorney are able to make a decision without communicating essential features of the decision to the adversary.

Id. at 153. 
but valuable evidence they sometimes find in "plam view" while executing a search. ${ }^{360}$ Such fortuitous discoveries cannot occur during a constructive search. This is clearly a loss, but one of uncertain inagnitude. Particularly when the search of a law office is at issue, the interest of all parties (imcluding the government) in avoiding a situation where police stumble inadvertently upon privileged and confidential materials, outweighs the loss of plain-view evidence that might be gathered during actual searches.

Against the weaknesses of the hybrid order one inust weigh its great advantages. Although physical evidence in a lawyer's hands might not be accessible to the government on exactly the same terms as it would be outside the lawyer's possession, the tenns of availability are nonetheless comparable, and we can remain reasonably certain that such evidence im the hands of a lawyer will not be altered or destroyed. Because of the greater likelihood that evidence will be preserved, any disadvantage to the government in working under the hybrid order procedure might be inore than offset.

2. Constitutional Objections. Surely there will be constitutional challenges to the hybrid order based upon Fisher's projected and act of production privileges. One claim would be that the mere label of "constructive search" fails to change the reality that compelled production of a Fifth Amendment variety is really at issue, in that testimonial commumications attend production pursuant to a hybrid order just as they attend comphance with an old-fashioned subpoena.

I have two answers to this anticipated claim. First, the hybrid order is fundamentally different than a subpoena because it is based upon probable cause and is issued in accordance with other procedures that closely track search warrant law. Such hurdles are not required for the issuance of a subpoena. When satisfied, they empower the governnient under the Fourth Amendment to make a full search of the lawyer's premises. In circumstances where the law would permit an actual search, it is hard to see why it should not permit the less intrusive device of a constructive search. Second, the fiction of a constructive search shields privileged and confidential materials belonging to the suspect himself and to the lawyer's other chents. It is no doubt also less of an imposition upon the lawyer himself than a real search. No one, even the suspect, would rationally object to a constructive search as held up against the actual search that is otherwise authorized.

360. See Horton v. California, 496 U.S. 128 (1990); Arizona v. Hicks, 480 U.S. 321 (1987); Coolidge v. New Hampshire, 403 U.S. 443 (1971). 


\section{CONCLUSION}

For many years there has been a parallax between an unrepresented criminal suspect's abstract rights to conduct a defense consistent with the rights of passivity granted by the Fifth Amendment and the abilities of criminal suspect with a lawyer to do the same. Obtaining a lawyer, $m$ the narrow circumstances of the Olwell decisions, is a bit like imviting a government agent into the defense camp. The holdings of the Olwell cases, which require attorneys to come forward with chent-incriminating evidence, have no regard for the client's passivity rights. Instead, the lawyer's duty runs to a coinpeting societal interest in law enforceinent.

The Olwell rule would likely have encountered the Fifth Amendment earher in its history, but for the fact that it is infrequently invoked. This infrequency is due in large part to internal defects, which suggest that the rule will have force ouly in a small percentage of cases. However, the infrequency is also attributable to the curious failure of the courts to apply Olwell to documentary evidence in white-collar criminal cases. If this failure is exposed as logically indefensible, as I think it is, Olwell will suddenly achieve a greater reach than we now recognize. Its importance, and the significance of its Fifth Amendment blindspot, will be magnified.

Olwell is not the only trouble spot for chents, lawyers, and the Fifth Amendment. Legal cominand cases, most notably the attorney-subpoena cases, are presently working their way through the courts in large numbers, and one inay soon find its way to the Supreme Court. As with Olwell, the lower courts have often viewed the compulsion of chent-incriminating evidence from a lawyer as an event having no bearing upon the client's self-mcrimination rights. Thus the once-narrow divergence between the passivity rights of represented and unrepresented suspects is now widening at a steady pace.

The legal command cases are not uniformly insensitive to Fifth Amendment issues. In fact, Fisher, the only major Supreme Court case to address the problem of coinpelled production of evidence through counsel, ultimately rested on Fifth Amendment principles. Through a mampulation of the attorney-chent privilege, Fisher allowed a simulated assertion of chents' passivity rights by their attorneys. Although Fisher can be read restrictively, the lower courts passing upon legal command issues should attend to its underlying logic: If not through the Constitution, then through the law of privileges, counsel should be permitted to assert their clients' Fifth Amendinent rights when compelled to produce evidence or information lawfully acquired during the representation. 
My suggestion for the range of problems studied in this Article is a simple one: By constitutional mandate or in our other laws, we should extend a projected Fifth Amendment privilege to defense counsel. The effect of such a privilege would be to inject issues concerning the client's passivity rights into settings where they are now considered irrelevant. Such a change would not mean that all obligations upon lawyers to produce chent-mcriminatimg evidence, by legal command or otherwise, would evaporate. It would mean, however, that such production issues would be resolved in the same way for both lawyer and client.

In conjunction with the projected privilege, the law must also address the question of how physical evidence may be obtained from lawyers. Once again, the guidimg principle should be an equalization of the situations of represented and unrepresented suspects. The "liybrid order" that I have proposed attempts to inake evidence in a lawyer's possession available to the government under the searcli and seizure power on ternis comparable to its availability if it had remained in the hands of the chent or any private party. While the projected privilege seeks to ensure that a chient's constitutional riglits are not diminislied merely because he obtains counsel, the hybrid order works to ensure that they are not eularged.

The time for a projected Fifth Amendment privilege may be upon us. Historically, the law of privileges has developed in response to the use of new and imtrusive investigative techmiques im crimmal or civil litigation. Arguably, the seeds of the projected privilege were sown in 1964 when Olwell was decided. For reasons suggested above, lowever, the Olwell rule has exerted limited impact upon the practice of criminal defense law, and has shown sigus of collapsing under its own weight. In the 1980s and early 1990s, however, the so-called war against defense counsel has raised the fundamental issues of Olwell once again, more forcefully than before, and with no sigu of collapse. It is time, therefore, to reconsider the full landscape presented by these related problems, and whether we will allow so many of them to be resolved as though the rights of passivity guaranteed im the Fiftl Amendment did not exist. 